\title{
Analysis and Comparison of Biomass Pyrolysis/Gasification Condensates - An Interim Report
}

D. C. Elliott

September 1985

Prepared for the U.S. Department of Energy under Contract DE-AC06-76RLO 1830

Pacific Northwest Laboratory

Operated for the U.S. Department of Energy by Battelle Memorial Institute 


\title{
DISCLAIMER
}

This report was prepared as an account of work sponsored by an agency of the United States Government. Neither the United States Government nor any agency thereof, nor any of their employees, makes any warranty, express or implied, or assumes any legal liability or responsibility for the accuracy, completeness, or usefulness of any information, apparatus, product, or process disclosed, or represents that its use would not infringe privately owned rights. Reference herein to any specific commercial product, process, or service by trade name, trademark, manufacturer, or otherwise, does not necessarily constitute or imply its endorsement, recommendation, or favoring by the United States Government or any agency thereof. The views and opinions of authors expressed herein do not necessarily state or reflect those of the United States Government or any agency thereof.

\author{
PACIFIC NORTHWEST LABORATORY \\ operated by \\ BATTELLE \\ for the \\ UNITED STATES DEPARTMENT OF ENERGY \\ under Contract DE-AC06-76RLO 1830
}

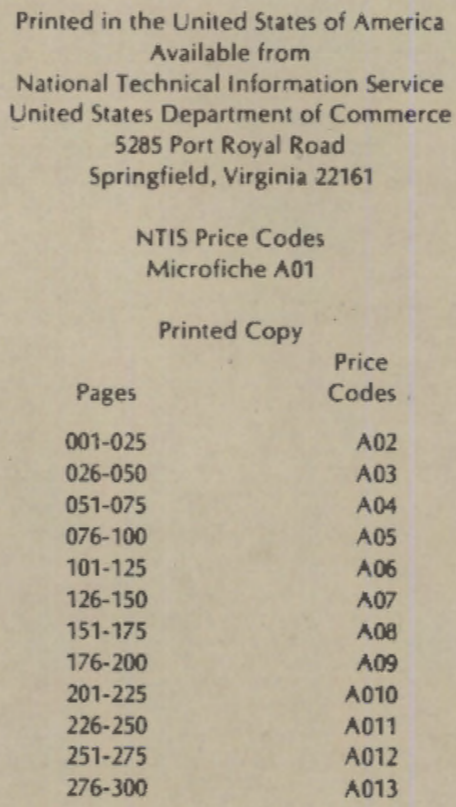


PNL -5555

UC $-61 \mathrm{a}$

\title{
ANALYSIS AND COMPARISON \\ OF BIOMASS PYROLYSIS/GASIFICATION \\ CONDENSATES - AN INTERIM REPORT
}

\author{
D. C. Elliott
}

September 1985

Prepared for

the Biofuels and Municipal Waste Technology Division U.S. Department of Energy

under Contract DE-AC06-76RL0 1830

Pac if ic Northwest Laboratory

Richland, Washington 99352 


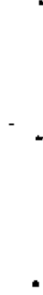

$\checkmark$ 


\section{SUMMARY}

This report provides results of chemical and physical analysis of condensates from eleven biomass gasification and pyrolysis systems. The analyses were performed in order to provide more detailed data concerning these condensates for the different process research groups and to allow a determination of the differences in properties of the condensates as a function of reactor environment. The analyses were performed on condensate samples provided by the reactor operators and are considered representative of the operating conditions given but they are not necessarily representative of optimum operating conditions in the specific reactors.

The samples were representative of the various reactor configurations being researched within the Department of Energy, Biomass Thermochemical Conversion program. The condensates included tar phases, aqueous phases and, in some cases, both phases depending on the output of the particular reactor system. The analyses included gross compositional analysis (elemental analysis, ash, moisture), physical characterization (pour point, viscosity, density, heat of combustion, distillation). specific chemical analysis (gas chromatography/mass spectrometry, infrared spectrophotometry, proton and carbon-13 nuclear magnetic resonance spectrometry) and biological activity (Ames assay).

These results are from the first phase of a longer term program to determine the properties, handling requirements, and utility of the condensates recovered from biomass gasification and pyrolysis. The analytical data demonstrates the wide range of chemical composition of the organics recovered in the condensates and suggests a direct relationship between operating temperature and chemical composition of the condensates. A continuous pathway of thermal degradation of the tar components as a function of temperature is proposed. Variations in the chemical composition of the organic components in the tars are reflected in the physical properties of tars and phase stability in relation to water in the condensate. The biologica? activity appears to be 1 imited to the tars produced at high temperatures as a result of formation of polycyclic aromatic hydrocarbons in high concentrations. Future studies of the time/temperature relationship to tar composition and the effect of processing atmosphere should be undertaken. Further processing of the condensates either as wastewater treatment or upgrading of the organics to useful products is also recominerided. 

INTRODUCTION

BACKGROUND

Review of the 01d Technology . . . . . . . 3

Similarities between Wood Tar and Coal Tar Chemistry : . . . 6

Recent Research and Operational Results . . . . . . . 7

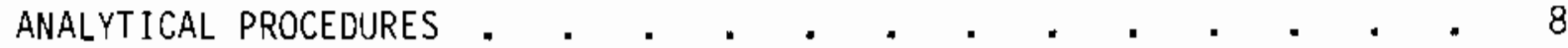

Elemental Analysis. . . . . . . . . . . . . 8

Ash . . . . . . . . . . . . . . . 8

Density . . . . . . . . . . . . . . . 9

Viscosity . $\cdot$. . . . . . . . . . . . . 9

Moisture . . . . . . . . . . . . . . 9

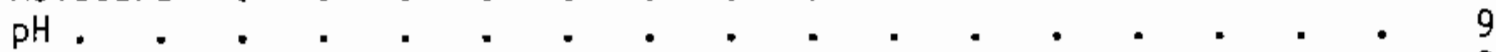

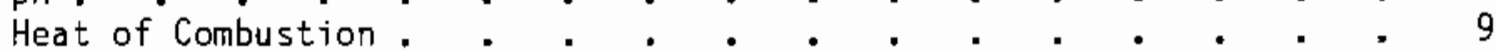

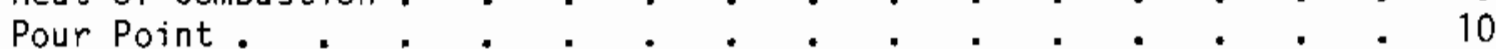

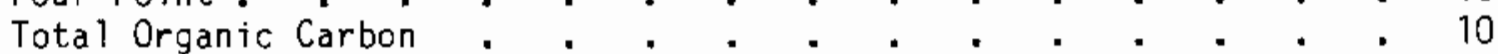

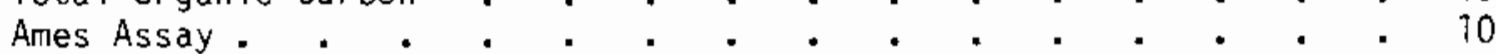

Gas Chromatography/Mass Spectrometry . . . . . . . . . 11

Infrared Spectrophotometry. . . . . . . . . . . 12

Nuclear Magnetic Resonance Spectrometry . . . . . . . . 12

Vacium Distillation . . . . . . . . . . . . 13

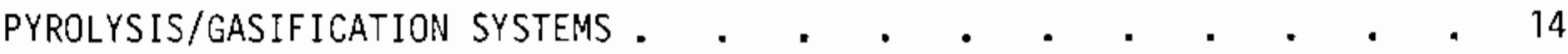

Entrained-Flow Pyrolysis . . . . . . . . . . . . . 14

Georgia Tech Entrained-Flow Pyrolysis . . . . . . . . 14

SERI Entrained-F Tow, Fast Ablative Pyrolysis : $:$. $:$. $\quad$ : 16

Updraft Gasification . . . . . . . . . . . . . . . . 19

Downdraft Gasification . . • . . . . . . . . . . 19

SERI Stratified Downdraft Gasification . . . . . . . . 19

Cal Recovery Systems Biomass Gasification . . . . . . . . 22

University of Florida Biomass Gasification . . . . . . . . 22

Rocky Creek Farm Gasogens . . . . . . . . . . . . . 25

Fluidized-Bed Gasification . . . . . . . . . . . . . . . 25

BCL Multi-Solids Fiuidized Bed Gasification . . . . . . 25

IGT Pressurized Biomass Gasification . . . . . . . . . . 28

PNL Catalytic Steam Gasification . . . . . . . . . 30

University of Missouri-Rolla Fire Tube Gasification System . . . 30 


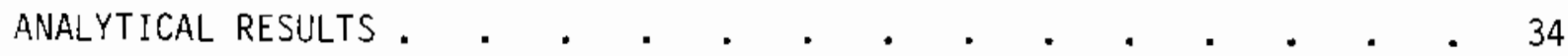

Gross Compositional and Physical Analysis . . . . . . . . 34

Tar Phase Analysis . . . . . . . . . . . . 34

Aqueous Phase Analysis. . . . . . . . . . . . . 35

Specific Chemical Analysis. . . . . . . . . . . . . . 37

Tar Phase Anatysis. . . . . . . . . . . . 37

Aqueous Phase Analysis. . . . . . . . . . . . . . . . 39

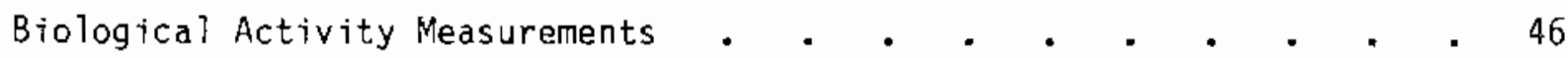

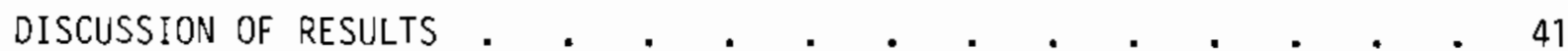

The Effect of Processing Conditions . . . . . . . . . . . 41

Chemica 1 Compositional Changes. . . . . . . . . . . . 43

Condensate Processing As Gasification Byproducts . . . . . . 43

Biological Activity of Condensates . . . . . . . . . . . . 46

SUGGESTIONS FOR FUTURE RESEARCH . . . . . . . . . . . . . 48

Additional Analysis of Condensates from Operating PRUs . . . . . 48

Detailed Study of Tar Conversion Chemistry from $450^{\circ}$ to $950^{\circ} \mathrm{C}$. . . . 49

Aqueous Byproduct Treatment Studies . . . . . . . . . 50

Tar Byproduct Treatment Studies . . . . . . . . . . . . . 50

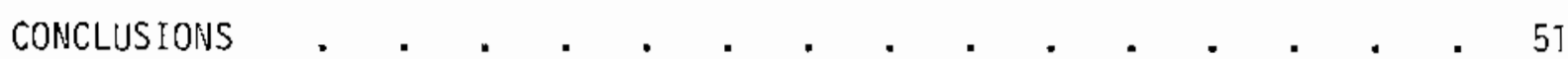

ACKNOWLEDGEMENT . . . . . . . . . . . . . . . . 52

REFERENCES • . . • . . . . . . . . . . . . . . . 53

APPEMDIX A - DISTILLATION CURVES FOR BIOMASS PYROLYSIS/

GASIFICATION TARS . . . . . . . . . . . . A.1

APPENDIX B - INFRARED SPECTRA OF BIOMASS PYROLYSIS/GASIFICATION TARS • B. 1

APPENDIX C - PROTON AND CARBON-13 NUCLEAR MAGNETIC RESONANCE SPECTRA OF BIOMASS PYROLYSIS/GASIFICATION TARS . . . . . . . C.

APPENDIX D - CHEHICAL COMPONENTS IDENTIFIED BY GAS CHROMATOGRAPHY/MASS SPECTROMETRY AND QUANTIFIED BY GAS CHROMATOGRAPHY (FID)

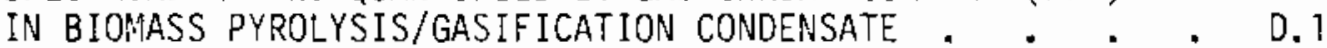

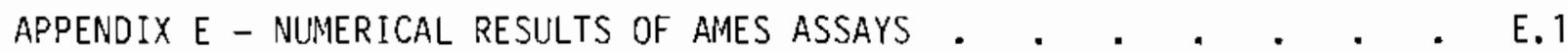




\section{LIST OF FIGURES}

1. Georgia Tech Entrained Flow Pyrotysis Research Unit . . . . 15

2. SERI Ablative Pyrolysis System . . . . . . . . . . 17

3. Updraft Woodchip Gasification System at Rome, Georgia . . . . 20

4. SERI Transparent Downdraft Gasifier . • • . . . . . 21

5. Cal Recovery Systems Experimental Gasification System . . . . . 23

6. Cross-Sectional View of Downdraft Gasifier Used by the University

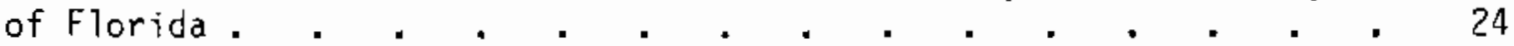

7. Rocky Creek Gasogens Gasifier . . . . . . . . . . . 26

8. Battelle's Biomass Gasification Unit . . . . . . . . . 27

9. IGT Process Researach Gasifier . . . . . . . . . . . 29

10. PNL Bench-Scale Gasification Equipment . . . . . . . . . . . 31

11. University of Missouri-Rolla Biomass Gasification Unit. . . . . 32

12. Shift in ChemicaT Composition of Aqueous Phase from Fluidized Bed Gasifiers. . . . . . . . . . . . 44

13. Phenol Content vs. Naphthalene Content of Coke-Oven Tars . . . 45

\section{LIST OF TABLES}

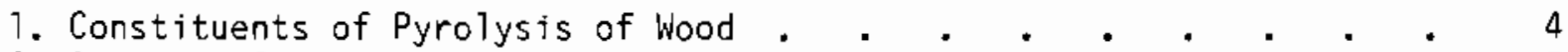

2. Products Identified in the Pyroligneous Acid of Wood . . . . 5

3. Gross Compositional Analysis of Tars . . . . . . . . . . 34

4. Composition of Tars on a Dry Basis. . . . . . . . . . . . . 35

5. Physical Characterization of Tars . . . . . . . . . . . . 36

6. Gross Compositional and Physical Analysis of Aqueous Phases . . 38 


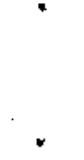




\section{INTRODUCTION}

This report describes the Phase ? effort on a project titled "Comparative Analys is of Pyrolys is Tars" which was funded through the Thermochemical

Conversion Program Office by the Biomass Energy Technology Division (BETD) of the U.S. Department of Energy. The purpose of this project was to analyze the condensate byproducts from the eleven process research units (PRUs) which were being funded by BETD. The analytical results were to be used in three ways:

1. provide useful descriptive data on the composition and properties of the condensate for use by the researchers to evaluate and develop their processes,

2. identify the relationship of biomass tar properties and gasifier operating conditions in order to develop a global theory which could describe the effects of gasifier environments on tar properties, and

3. suggest areas requiring additional study including a projection of the utility of such research.

Previous to this report the analytical results from these analyses were sent to the respective researchers as a series of reports numbered $1 \mathrm{~A}$ through $1 \mathrm{~K}$. A report number 2 was also issued which provided additional analytical results on several of the condensate samples and several additional samples. This report is a collection of all the data in the earlier reports \#1A through \#1K and $\$ 2$ and includes a discussion and comparison of the results as well as a discussion concerning the theory of condensate formation.

This analytical project could not be possible without the cooperation of the individual researchers who have responsibility for the gasification/pyrolysis PRUs in the BETD program. The samples and processing information were provided by the following people:

$$
\begin{aligned}
& \text { Mr. Robert H. Hargrave } \\
& \text { Mr. Herman F. Feldmann } \\
& \text { Mr. Mark A. Paisley } \\
& \text { Dr. Suresh Babu } \\
& \text { Dr. James P. Diebold } \\
& \text { Dr. James A. Knight } \\
& \text { Dr. Virgil J. Flanigan } \\
& \text { Mr. George Savage }
\end{aligned}
$$

Rocky Creek Farm Gasogens Inc. LaCrosse, Florida Battelle Columbus Laboratories $(B C L)$
Columbus, Ohio

Institute of Gas Technology (IGT) Chicago, Illinois

Solar Energy Research Institute (SERI) Golden, Colorado

Georgia Institute of Technology Atlanta, Georgia

University of Missouri - Rolla Rolla, Missouri

Cal Recovery Systeris Richmond, California 


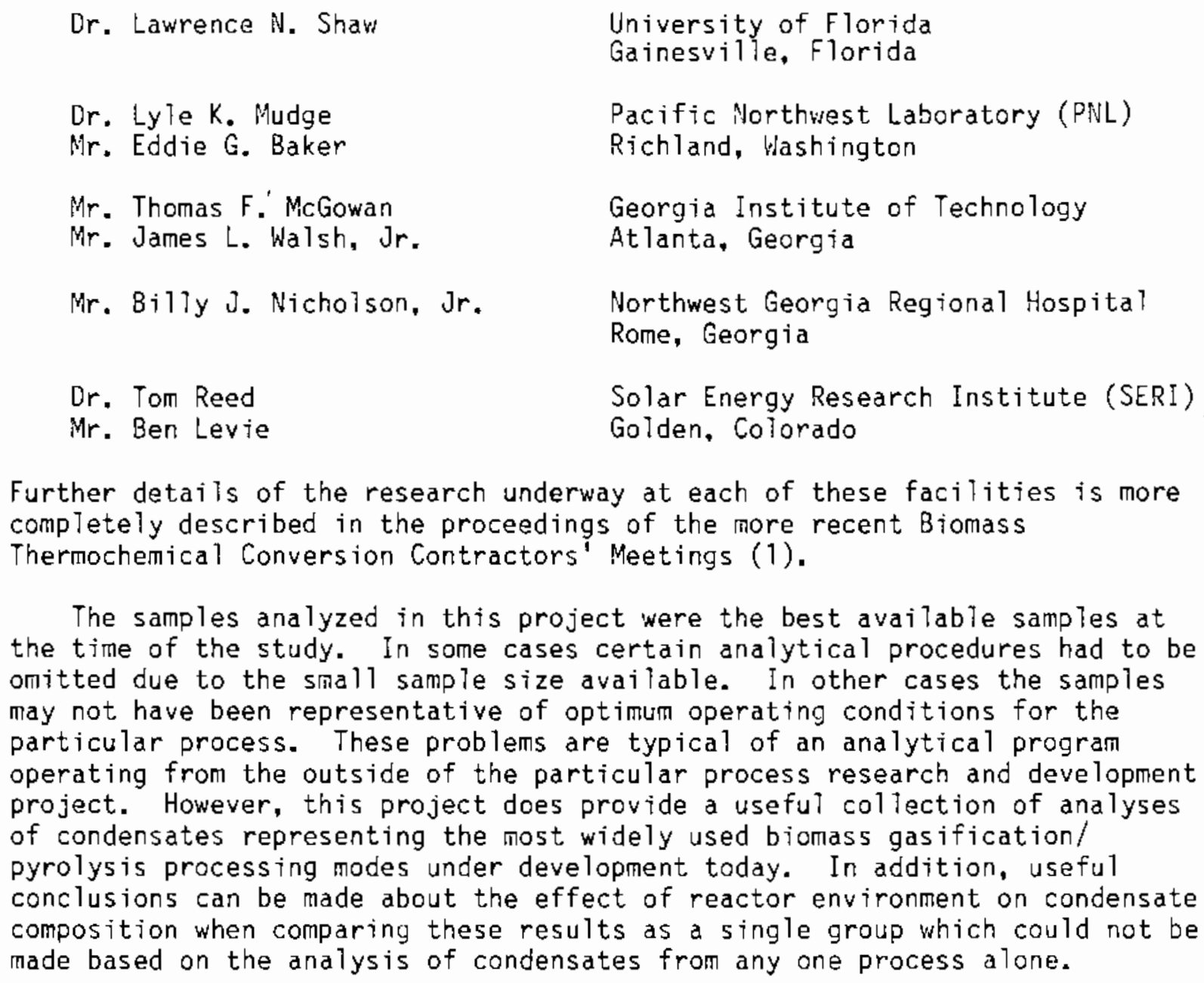

Further details of the research underway at each of these facilities is more completely described in the proceedings of the more recent Biomass

Thermochemical Conversion Contractors' Meetings (1).

The samples analyzed in this project were the best available samples at the time of the study. In some cases certain analytical procedures had to be omitted due to the small sample size available. In other cases the samples may not have been representative of optimum operating conditions for the particular process. These problems are typical of an analytical progran operating from the outside of the particular process research and development project. However, this project does provide a useful collection of analyses of condensates representing the most widely used biomass gasification/ pyrolysis processing modes under development today. In addition, useful conclusions can be made about the effect of reactor environment on condensate composition when comparing these results as a single group which could not be made based on the analysis of condensates from any one process alone. 


\section{BACKGROUND}

The thermal decomposition of biomass by partial oxidation, steam reforming or simple pyrolysis is well known as a means to transform the solid biomass into fuel gases, tar byproducts and solid chars. Throughout most of the development work on these types of processes the emphasis has been either on the production of fuel gases or solid fuel char. The liquid products have almost invariably been considered byproducts which have found more or less utility depending on the ingenuity of the process designer. The lack of utilization of the liquid byproduct can be traced to its complex chemical nature as well as the difficulty in cleanly separating the polar organic components from the water condensate. Only the most recent technologies under development have actualiy managed to efficiently produce a liquid product in high yields directly by thermal treatment of bionass.

The thermochemical conversion of biomass to traditional solid char or gaseous fuels invariably produces some tars in the process. The production of char through pyrolysis of biomass by known processes leaves no option but to produce a major tar byproduct stream which must be dealt with. Most attempts at gasification of raw biomass have sought to minimize the tar byproduct as it complicates the utilization of the gas product. Gasifying biomass char as opposed to raw biomass is one option which eliminates tar production during gasification but actualiy only moves the tar problem to another site. Gasifier design to convert tar to gas during the gasification has been the primary emphasis and has met with varying degrees of success.

Given that a tar product from thermochemical conversion of biomass is unavoidable, an understanding of its chemical and physical properties becomes a necessary part of process development. Whether the liquid is the major product as in low-temperature, fast pyrolysis or only a troublesome byproduct as in gasification, the properties of the tar must be known in order to devise engineening solutions for dealing with the tar. Analysis of the tar is necessary in order to determine the means of utilizing or disposing of the tar through any of a wide variety of means involving either fractionation, or chemical and biological transformations. With sufficient understanding of tar properties, such fractionations or transformations might be designed into a conversion process or added afterward as product or byproduct treatment.

\section{REVIEW OF OLD TECHNOLOGY}

The pyrolysis of biomass to produce char, gas, tars and aqueous organic condensates (pyroligneous acid) has been known since some of the earliest stages of civilization. The ancient Egyptians used pyroligneous acid from hardwood as an embalming fluid (2). Detailed chemical analysis of the product being used was unknown and only came much later. During the later half of the nineteenth century refining of the condensates from wood char production was developed (3). Attempts to analyze wood tar and identify its components date from the early part of this century (4). Tables 1 and 2 are early lists of chemicals produced by pyrolysis of wood and are indicative of the type of product which is formed at temperatures up to about $500^{\circ} \mathrm{C}$. A more extensive table has also been produced ( 3 ). 
Table 1. Constituents of Pyrolysis of Wood (adapted from Ref. 4).

formic acid

acetic acid

propanoic acid

3-methylpropanoic acid

2-methylpropenoic acid

butanoic acid

2-butenoic acid

2-methyl butanoic acid

cis-2-methyl-2-butenoic acid

trans-2-methyl-2-

butenoic acid

pentanoic acid

2-pentenoic acid

4-methylpentanoic acid

hexanoic acid

heptanoic acid

tetracosanoic acid

forma ldehyde

acetaldehyde

propanal

butana]

2-methylpropana?

2,2-dime thylpropanal

acetone

2-butanone

2,3-butandione

3-methylbutan-2-one

2-pentanone

3-pentanone

2-hexanone

3-hexanone

3-hexen-2-one

3,6 -octandione

cyclopentanone

2-methy 1-2-

cyclopentenone

hydroxymethyl

cyclopentenone

cyclohexanone

methy Tcyclohexenone

dimethylcyclohexenone dimethoxyme thane

1, 1-dimethoxyethane

furan

2-methylfuran

3-methylfuran

dimethylfuran

2,5-dimethyl tetrahydrofuran

trimethylfuran

5-ethyl-2-methy $1-4,5$

dihydrofuran

furfura 7

5-methy? furfural

hydroxymethy 1 furfural

acetylfuran

2-furancarboxy? ic acid

benzofuran

pyroxanthone

phenoi

$0-, \mathrm{m}-$, and $\mathrm{p}$-cresol

o-ethylphenol

2,4-dimethylpheno?

3,5-dimethylpheno?

catecho?

2-methoxyphenol (guaiacol)

hydroxygua iaco?

4-methyl-2-me thoxyphenol

4-vinyl-2-methoxyphenol

4-ethyl-2-methoxypheno 1

4-propyl-2-methoxyphenol

1.2-dimethoxyphenol (syringol)

4-methy $1-2,6-$ dimethoxy phenol

4-propy 1-2, 6-dimethoxy phenol

coerolignol (or-on)

euppittonic acid

(or eupitton) carbon monoxide

carbon dioxide

hydrogen

water

methane

methyi alcohol

ethyl alcohol

2-propenol

propanol

1-methyl-2-propenol

3-methylpropanol

4-methylbutanol

$\gamma$-butyrolactone

$\gamma$-valerolactone

benzene

toluene

m-xylene

isopropy Tbenzene

isopropyl to iuene

$1,2,4,5$-tetramethyl-

benzene

naphthalene

chrysene

heptadecane

octadecane

eicosane

heneicosane

docosane

tricosane

ammonia

methylamine

dimethylamine

trimethylamine

pyridine

3-methylpyridine

dimethylpyridine 
Table 2. Products Identified in the Pyroligneous Acid of Wood (adapted from Ref. 4).

formic acid

acetic acid propionic acid

butanoic acid

pentanoic acid

hexanoic acid

2-butenoic acid

2-methyl-2-butenoic acid

catechol

pyroxanthen

ammonia methyl alcohol

2-propenol

3-methylpropanol

4-methylbutano?

acetaldehyde

acetone

2-butanone

2-pentanone

3-hexanone

cyciopentanone

2-methylcyclopentanone methyl formate

methylace tate

dimethoxymethane

1,1-dimethoxyethane

valerolactone

furfural

methylfurfural

pyridine

methylamine

pyridine

methylpyridine

The main product from wood pyrolysis has invariably been the solid char product which is a cleaner burning, more energy dense fuel than the wood. Solid char production was therefore maximized by process optimization and the organic condensates were merely byproducts which were consistently recovered in only the more efficient operations. Although acetic acid and methanol were once produced in significant quantities through hardwood pyrolysis, the last acetic acid recovery plant operating in the U.S. was closed in 1972 (2). By that time, wood char had long since been supplanted by fossi] fuels.

Processes to produce fuel gas from biomass have also undergone significant development during the past century. Of the early gasifier configurations either the updraft or downdraft versions were favored depending on the appication. The updraft gasifier is operated as a countercurrent flow reactor with both biomass feed entering and product offgas exiting the top of the reactor. Air was blown from the bottom of the stationary bed. This system las positive attributes including maximum heat recovery, low temperature exit gas, drying and devolatilization of green fuels and minimal contamilation of fuel gases with solids but it tends to produce a tar laden gas (7). The downdraft gasifier is operated as a cocurrent flow reactor with product gas leaving the bottom of the reactor. This system was favored for transportation systems with internal combustion engines due to its cleaner gas product (8). In fact, updraft gasifiers have been designed for use with internal combustion systems but could only be operated with a processed feedstock such as coke or char so that tar formation was preempted (9).

The early biomass gasification literature contains almost no analytical data on the composition of gasification byproduct tar or condensate streams. Apparently the tars are considered to be equivalent to typical pyrolysis tar. The tar mists produced in downdraft gasifiers are discussed to a 1 imited degree and are considered by one source to be phenols with some acetic acid. It is stated that the aqueous condensates are almost always alkaline (due to ash carry over) (8). The production of a truiy tar-free gas from biomass remiains to be accomplished and claims to the contrary in the early literature have been dismissed as "mostly misleading" (4). A statement in a recent survey of gasification is particulary telling: "There does not appear to be any research on the question of how well the tarry vapors obtained from gasification of coal and biomass are cracked under the moderate conditions of 1 atm pressure and temperatures around $1000-1200^{\circ} \mathrm{C}^{\prime \prime}$ (4). 
Strong analogies can be made between coal tar and wood tar formation. Coal tar is defined as either low temperature or high temperature tar. The low temperature tar is generally defined as that produced well below the temperatures used in coke ovens. The upper temperature limit for true low temperature tar is about $500^{\circ} \mathrm{C}$ because aromatization reactions become significant at about $600^{\circ} \mathrm{C}(10)$. The outstanding chemical characteristic of low temperature coal tar is the large number of chemical components including a wide variety of chemical functional groups all of which are in small quantities. This condition is unlike high temperature tar wherein a single component such as naphthalene can make up as much as $10 \%$ of the tar (70).

Unjike the case of wood tars, low temperature coal tar has received much less attention than the high temperature tar. Low temperature coal carbonization does not yield the commercially useful quantities of acetic acid and methanol which wood does. The classic methods of organic chemistry which were applied extensively to high temperature coal tar were of little use with the low concentration components in the low temperature tar. In addition, the high temperature tars are comparatively uniform in composition and have little variation as a function of coal. This statement does not hold for low temperature tars (10).

High temperature coal tar is formed at temperatures in excess of $800^{\circ} \mathrm{C}$ as a conversion product of the primary pyrolysis products of coal (11). Water, ammonia, hydrogen sulfide, carbon dioxide, methane, and hydrogen are eliminated in processes resulting in ring closures, condensation, unsaturation and aromatization. The reactions resulting in these changes are cracking and cyclization of paraffins, dehydrogenation of cycloparaffins, dehydration of phenols, and dealkylation of aromatic hydrocarbons and heterocyclic ring compounds. Thermodynamic considerations suggest that these would be the reactions occurring at the typical temperatures of high temperature carbonization (12). The high degree of conversion typical of this processing is shown by the almost $100 \%$ content of polycyclic aromatic hydrocarbons (PAH) found in the tar. Temperature related effects which have been measured are the decrease in tar acids and the increase in unsubstituted PAH with an increase in carbonization temperature. The high-temperature stability of PAH compounds is attributed to the resonance energy associated with the conjugated double-bond system (11). The same kinds of chemistry undoubtedly occur during the formation of wood tar at high temperatures.

Consideration of the toxic properties of coal tars also provides insight into the potential properties of wood tars. Acute toxicity appears to be limited to the more volatile mononuclear aromatic hydrocarbons, phenols and tar bases. The PAH are primarily eye and skin irritants. The more common heaith hazard attributed to coal tar is carcinogenicity. Research of the past 60 years has well documented the susceptibility of rats to develop malignancies when exposed to PAH. This mutagenic activity is typically found in the higher molecular weight PAH such as dibenzanthracenes and dibenzpyrenes but has been attributed to PAH as small as benz(a)anthracene (12). 


\section{RECENT RESEARCH AND OPERATIONAL RESULTS}

Most of the current research in biomass pyrolysis/gasification continues to identify tar as a generalized product without specifying the composition of the material. Few studies have considered the difference in chemical composition of a wood tar produced at $500^{\circ} \mathrm{C}$ in a pyrolysis unit compared to the tar produced at $800^{\circ} \mathrm{C}$ in a gasification unit. The first clear statement of the difference between low temperature wood pyrolysis tar and high

temperature cracked tar appears in the proceedings of a specialists workshop on pyrolysis of biomass in 1980 (13).

The production of organic tar material from biomass by thermal treatment is highly dependent on operating temperature. The amount of tar production apparently peaks at around $500^{\circ} \mathrm{C}(14,15,16)$ and increasing temperature above $600^{\circ} \mathrm{C}$ results in decreasing levels of tar $(14,16,17,18,19)$. The decreasing amount of tar production is widely attributed to cracking of the tar molecules to lighter components $(14,17,18)$. That the composition of the remaining tar changes as the cracking reactions progress is often ignored. Only limited analysis of the higher temperature tars is available. A recent gasification modeling effort was plagued by the lack of a coherent understanding of the variation of tar composition as a function of operating conditions (20). Although polynuclear aromatic hydrocarbons have been identified in addition to the phenolic materials widely reported in the older literature of the pyrolysis oils $(21,22)$ no serious attempt has been made to quantify the differences in chemical composition of gasifier tars as a function of operating conditions. Continuing work at the Solar Energy Research Institute supports a conversion mechanism of initial pyrolysis products to more condensed aromatic compounds by higher temperature processing $(14,23)$.

The aqueous condensate which contains dissolved organic constituents is present in almost all cases of thermal processing of biomass. In the low temperature pyrolysis systems, this phase is a well known source of methanol and ace"ic acid. The aqueous condensate has undergone limited analysis as a byprodus:t from high temperature gasifiers as wel1; trace metals and dissolved organics have been reported $(22,24,25)$. 


\section{ANALYTICAL PROCEDURES}

The analytical procedures described in this report are derived from a number of sources. For the most part these procedures have been developed over the period of the last eight years at Pacific Northwest Laboratory $(28,29)$ in support of the DOE-funded biomass liquefaction research effort. These procedures are in turn a combination of modern instrumental chemical analytical techniques. American Society of Testing Methods (ASTM) standard methods for petroleum products and modified procedures specifically adapted for biomass-derived liquids. The specific analyses were chosen to provide a chemical and physical characterization of the product so that comparisons could be made and correlations between properties and operating conditions could be identified. The analyses were performed on the tars and aqueous samples "as received." The elementa? composition of the tars is reported in the Results Section both as anafyzed and calculated on a dry basis.

\section{ELEMENTAL ANALYSIS}

For analysis of carbon, hydrogen, nitrogen and oxygen, the Perkin-Elmer 240 and 2408 analyzers were used. Sulfur analys is could not be performed with these instruments due to the low level of concentration. The concentration of nitrogen was also at or below the limit of detectability with the P-E 240 . The P-E 240 determines carbon, hydrogen and nitrogen by detecting and measuring their combustion products $\left(\mathrm{CO}_{2}, \mathrm{H}_{2} \mathrm{O}\right.$ and $\left.\mathrm{N}_{2}\right)(30)$. Combustion occurs in pure oxygen under static conditions and the products are analyzed by thermal conductivity. Helium is used to carry the combustion products from the combustion furnace through a reduction tube (which reduces any $\mathrm{NO}_{\mathrm{x}}$ ) and through the series of detectors and traps. For oxygen analysis, a separate sample must be pyrolyzed in helium over platinized carbon so that oxygen is converted to carbon monoxide. The carbon monoxide is scrubbed free of acid gases and then oxidized and measured as carbon dioxide. In all cases, the instrumental readout is in millivolts, from which the composition is calculated based on reference compounds.

Sulfur and other trace elements were determined by energy-dispersive $x$-ray fluorescence using a combination of titanium and zirconium excitation sources. A dual-spectrum backscatter parameter matrix correction method was used in the analyses to provide increased sensitivities over a wider range of elements (31). With this dual source system the suite of elements measured extends from aluminum to strontium (excluding germanium, scandium and the noble gases) and also includes mercury and lead. All elements not listed in the table of analytical results were present at levels less than $100 \mathrm{ppm}$ while the following environmentally sensitive elements were not 1 isted if found to be below the levels 1isted here: $\mathrm{Hg}<5 \mathrm{ppm}, \mathrm{Pb}<1 \mathrm{ppm}, \mathrm{Cl}<60 \mathrm{ppm}$, As $<1 \mathrm{ppm}$, and $\mathrm{Se}<1 \mathrm{ppm}$.

$\underline{\text { ASH }}$

Ash was determined by combustion in a muffle furnace similar to ASTM method, D-482-80 (32). This method covers determination of ash from distillate and residual fuels, crude oils and other petroleum products. Porcelain crucibles with Tids were used throughout. 


\section{DENSITY}

The use of glass hydrometer bulbs in a cylinder filled with product is the preferred method for density measurement. The Timited quantities of some products forced the use of weighed volumes of product for calculation of the density. In other cases, the high viscosity of the product forced the measurement of displaced water for a volume/mass measure. The use of a temperature-controlled water bath facilitated measurements at the elevated temperatures which were necessary to make several of the products fiuid enough to allow the measurements.

\section{VISCOSITY}

Viscosity measurements were performed with a Brookfield Synchro-Lectric Viscometer with a small sample adapter and utilizing a constant temperature water bath. In operation, the Synchro-Lectric Viscometer rotates a cylinder. called a spindle, in a fluid and measures the torque necessary to overcome the viscous resistance to the induced movement. This is accomplished by driving the immersed cylinder through a beryllium-copper spring. The degree to which the spring is wound is indicated by the position of a pointer on the viscometer dial and is proportional to the viscosity of the fluid for any given speed and spindle. The viscometer is able to measure over a number of ranges since, for a given dray, or spring deflection, the actual viscosity is proportional to the spindle speed and is also related to the spindle's size and shape (33).

\section{MOISTURE}

Moisture analysis in gasifier tar condensates is particulariy important due to the large effect water has on other parameters such as the heating value, fluid properties and volatility. The Karl Fischer titration was used in this study by means of the Aquatest IV unit by Dol. In this instrument the reagent is electrolytically generated in the presence of water. By means of a sensing electrode the instrument generates enough reagent to react with the water in the sample and calculates the water content based on the use of direct current electricity for electrolysis. A secondary check of water content was available from the vacuum distillation. Moisture analysis was not performed on the condensates which were primarily water.

pH

An approximation of the $\mathrm{pH}$ of the aqueous condensates was made using a series of quantitative $\mathrm{pH}$ papers. No attempt was made to degas the samples prior to the measurement.

\section{HEAT OF COMBUSTION}

Heats of combustion were obtained by combustion of the products in a Parr oxygen bomb calorimeter. An adiabatic system is maintained through the use of a controlled temperature water bath. Combustion of the samples in the bomb is a straight forward procedure; however, some difficulty with ignition of the samples was noted due to the large percentage of water in the tars. In these cases a fine cotton thread was used as a wick as suggested by the manufacturer 
(34). Heats of combustion could not be performed on the condensates which were primarily water.

POUR POINT

Pour point was determined in a pyrex beaker approximating the procedure of ASTM-D-97-66 (32). The pour point is the lowest temperature at which an oil is observed to flow and approximates the lower limit at which a fuel oil can be pumped from storage. Pour points were not determined for the condensate samples which were primarily water.

TOTAL ORGANIC CARBON

Total organic carbon analysis was performed on aqueous samples in order to determine the low carbon contents of the aqueous streams. The analysis was performed with a Dohrman DC-80 instrument which performs a UV enhanced persulfate oxidation and measures carbon dioxide production with an IR detector. Prior to analysis the samples were filtered to remove particulate then acidified and sparged to eliminate carbonates and dissolved $\mathrm{CO}_{2}$ gas.

\section{AMES ASSAY}

Agar plate mutagenicity assays using S. typhimurium TA98 and TA100 (and in some cases TA1535 and TA7537 also) were carried out as described by Ames et al (35). DMSO was used as solvent for all of the chemical fractions.

Benzo(a)pyrene and 2-aminoanthracene were used as positive controls.

Revertant colonies were counted using a Biotran II automated colony counter

(New Brunswick Scientific Co., Inc., Edison, N.J.).

Mutagenic activity in revertant colonies, expressed as revertant colonies of $\mathrm{S}$. typhimarium/ug test material was estimated by linear regression analysis of dose-response data. A positive test was defined as having a maximum mutagenic response two-fold or greater above background, and a correlation coefficient 0.8 or above for the regression line with a positive slope.

The gasifier condensates in this study were assayed over three fixed concentration ranges of 100, 200,400, 500, 1000, $2500 \mu \mathrm{\mu g}$ per petri plate, 20, $40,80,100,200,500 \mathrm{\mu g}$ per petri plate, and 2, 4, 8, 10, 20, $50 \mathrm{\mu g}$ per petri plate. Several samples were also analyzed at low concentrations of .02, .04, $.08, .7,2.5 \mu$ per plate and .2, .4, .8, 1, 2, $5 \mu \mathrm{g}$ per plate. Each concentration was assayed in duplicate. Stock solutions of $10,000 \mu \mathrm{g} / \mathrm{ml}$ DMSO were prepared for use throughout these experiments and stored at $-80^{\circ} \mathrm{C}$ when not in $\lrcorner$ se.

To prepare liver homogenates Aroclor 1254 (Monsanto Chemical Corp.), at a concentration $250 \mu \mathrm{g} / \mathrm{kg}$ body weight, was injected intraperitoneally into male Wistar rats. The rats were sacrificed on the fourth day after injection. After sacrifice, the Jivers were perfused with ice-cold $0.154 \mathrm{M} \mathrm{KCl}$ and removed for preparation of $S 9$ homogenates, following standard procedures.

The Ames Assay is a widely used test for a preliminary measurement which suggests chemical activity for promoting primary DNA damage. In our analysis we have used the two most sensitive tester strains. However, it is possible that mutagens were present that were not detected, although based on avaifable 
data this is unlikely. Without more exhaustive tests it is not possible to draw firm conclusions as to the potential for promoting DNA damage.

\section{GAS CHROMATOGRAPHY/MASS SPECTROMETRY (GC/MS)}

Solutions of the various gasification tar products were prepared at a concentration of $5 \mathrm{mg} / \mathrm{ml}$ in methylene chloride and analyzed qualitatively by GC/MS. The column was a $60 \times 0.2510 \mathrm{~mm}$ DB-5 WCOT silica capillary purchased from $J \& W$ Scientific, Inc. The column was run directly to the source of a Hewlett-Packard 5985 GC/MS. The HP splitless injection system was used with an injector temperature of $200^{\circ} \mathrm{C}$ and an injection port pressure of 5 psig with helium carrier gas. The column temperature was programmed to $300^{\circ} \mathrm{C}$ at $5^{\circ} \mathrm{C} / \mathrm{min}$. with a starting temperature of $20^{\circ} \mathrm{C}$. The portion of the column passing through the transfer zone between the GC and the MS was maintained at $300^{\circ} \mathrm{C}$. The 70 ev electron impact spectra were recorded from 20 to $300 \mathrm{~m} / \mathrm{e}$ at a scan rate of $250 \mathrm{amu} / \mathrm{sec}$. One-microliter injections were used for these analyses.

Library searches are performed automatically using the Hew lett-Packard Probability Based Search (PBS) software. The search algorithm evaluates the significance of a match between the unknown spectrum and a library spectrum in terms of the probability that the match might occur by chance. The probability is rounded off so that it can be expressed as one chance in 10 to the $K$ power. Thus, ions which are very common will have a low value of $K$ and will also have little diagnostic value. Uncommon ions will have large $K$ 's and be highty significant in assigning identities to unknown substances. The sum of the $k$ values obtained by comparing the unknown to a library spectrum is taken as a measure of the quality of the fit. Using the PBS search technique has been found to give very reliable library searches given that the sample spectrum is relatively free of contaminants and the search parameters are judiciously chosen.

Whenever possible, identifications made on the basis of mass spectra were confirmed by comparison of the retention times and mass spectra of an authentic sample of the compound analyzed under identical conditions. The components which are unidentified are for the most part chemicals in very small concentrations which are not resoluble chromatographically. Based on routine study of the ion spectra from these compounds it can be stated that these compounds usually belong to the same chemical families as those identified.

The concentrations of each component in the tar products were estimated by GC with a flame ionization detector (FID) using the same conditions as for the GC/MS analyses except that the column head pressure was increased due to the increased pressure at the detector end. The MS data showed that resolution was adequate to obtain integration of single component peaks with the FID, and the FID was expected to give relative areas more accurately reflecting the mass concentration of each component than could be obtained from total ion or single ion peak area in the absence of a complete set of standards. However, the response of the FID is known to vary from compound to compound and is particularly affected changes in functional groups. In order to quantify the components without standardizing each one, the chemicals were separated into classes of compounds. The response of the FID was measured for representative members of each of the classes of compounds present. For example, the range 
of response factor values is 0.57 to 0.75 for oxygenated compounds, with the response of decane defined as 1.00. Thus, error based on the assumption of an average response factor for an entire class of compounds should not exceed $15 \%$ when areas are adjusted using the mean of the response factors found for oxygenated compounds (36). A response factor of 0.97 was used for the PAH components in the tars, based on the average response factor of naphthalene and anthracene. An internal standard, decane, was used to allow measurenent of loss of product in the chromatograph through decomposition or low volatility. For the study of the highly polar and thermally unstable tars in this program, loss of material within the chronatograph was a significant effect. Comparison of the actual amount of tar which could pass through the chromatograph can be used as a qualitative measure of the tar.

In the case of samples consisting primarily of water the concentration of the organic constituents was too dilute for GC/MS analysis. In these cases a methylene chloride extract was analyzed on the GC/MS to provide qualitative information only. This method provided a cusory view of the types of organic contaminents but the chromatography was designed primarily for the higher molecular weight components. As a result, the highly polar low molecular weight acids, alcohols and carbony?s were slighted by this analys is due to limitations of the extraction step as well as the chronatography.

\section{INFRAREO SPECTROPHOTOMETRY (IR)}

IR spectrophotometry was performed with a Perkin-Elmer 283. The model 283 is a double-beam, optical null instrument with a grating monochromator and operating range from 4000 to 200 wave numbers. Samples of the biomass gasification tar products, as received, were compressed to a thin film between two barium fluoride discs. The discs were then placed in the sample beam for analysis. Typical scan time from 4000 to 200 wave numbers was twelve minutes in a percent transmittance mode (37). No attempt was made at quantification of spectra. IR analysis of aqueous samples was not attempted.

The IR analysis is a useful study of the cherical functional groups in the whole tar. Analysis is not limited to volatile components as in the GC/MS. I-R provides a check on the GC/MS analysis by varifying the functional groups found in the volatile chemicals identified by GC/MS and also can confirm the absence of additional functional groups in the unidentified volatile components or the nonvolatile components.

\section{NUCLEAR MAGNETIC RESONANCE SPECTROMETRY (NMR)}

NMR studies of proton and carbon-13 nuclei were performed with a Varian FT-80A system. Deuterated chloroform was used as the internal standard for carbon-13 spectra and tetramethylsilane was the standard for proton spectra. The tars were dissolved in a solvent $\left(\mathrm{D}_{6}\right.$-acetone or $\left.\mathrm{COCl}_{3}\right)$ and filtered before analysis. NMR analysis was not performed on the aqueous samples.

The NMR provides additional confirmation of the chemical functional groups in the tar. The only limitation is that the tar components be soluble and the above-mentioned solvents were chosen for maximum solubility of the tar. 
A complete, quantitative distillation was performed with each tar product. When enough sample was available, a modified ASTM-D-1T60 apparatus and procedure were used. When lesser amounts of product were available, a conventional, short-path micro still was used.

The 0-1160-77 method specifies both a procedure and an apparatus for the distillation which provides approximately one theoretical plate fractionation (32). The apparatus which was used was the alternate column assembly including a vacuum jacketed reflux column as specified in the method. Our modification of the apparatus included the use of a mercury thermometer instead of the specified thermocouple and a vacuum manifold receiver which allowed the collection of separate product fractions without interruption of the vacuum or distillation. The distillation procedure was as specified in the method except the rate of $4-8 \mathrm{ml} / \mathrm{min}$. of distillate was never attained with the biomass gasification tar products.

Conversion of vacuum distillation data to atmospheric pressure was done with the use of a petroleum hydrocarbon vapor pressure chart with allowance made for the difference between the polar constituents of the gasification tars and hydrocarbons of petroleum. The amount of water in the sample was subtracted out of the reported distillation data, so that the distillation curve describes only the organic material in the product. This subtraction was based on moisture measurements and the distillation temperture in the cases wherein the water was miscible with the distillates. For the hightemperature products the water was immiscible with the distillates and could be measured directly.

Similar results were obtained with the short-path micro still distiliation apparatus. Distillation measurement and limited fraction separation were obtained with a calibrated "cow" receiver. Vacuum data were converted to atmospheric pressure in a manner similar to the 0-1160 data. 


\section{PYROLYSIS/GASIFICATION SYSTEMS}

The thermochemical conversion systems included in this study can be classified into four categories: entrained-flow pyrolysis, updraft gasification, downdraft gasification and fluidized-bed gasification. All of these systems were operating and sampled during the summer of 1984 except for the SERI entrained-flow unit. Al] of these systems were operating under contract. to DOE as part of the Biomass Energy Technology Division, Thermochemical Conversion Program except the Rome, GA, updraft gasifier which was sampled instead of the Georgia Tech updraft gasifier because the Georgia Tech un't was not operating during the summer of 1984.

\section{ENTRAINED-FLOW PYROLYSIS}

There are two entrained-flow pyrolysis units which were sampled as part of this program. Both produce a primary pyrolysis liquid product by short residence time thermal treatment at temperatures $\leq 500^{\circ} \mathrm{C}$ in inert gas. The SERI unit can also been operated with a second reactor to thermally treat the primary product at temperatures up to $850^{\circ} \mathrm{C}$.

\section{Georgia Tech Entrained-Flow Pyrolysis (38)}

A flow diagram of the Pyrolysis Research Unit is given in Figure 1, and its operation is described in the following. Propane gas [1] and air [2] supplied by an air compressor are burned stoichiometrically in an inert gas generator, and the combustion products are cooled with a water spray [3] so that the gases leave saturated with water vapor. The exit stream from the inert gas generator is Split into two streams. One of these [4] provides moderating gas for the burner and the other [5] provides conveying gas for the feed panticles [6]. Propane [7] also fuels the burner which also operates stoichiometrically with air [8] supplied by a blower.

The mixture consisting of moderating gas, conveying gas, burner combustion products, and wood particles moves vertically upwards through the reactor tube in which the entrained pyrolysis takes place. The reactor tube is an 8 inch, schedule 40, 304 stainless steel tube 21 feet long. The resulting mixture [9] consists of noncondensible gases, water vapor (entering moisture plus combustion and pyrolys is products), noncondensible gas, and pyrolys is oil vapors. In the cyclone, almost all of the char particles [10] are removed, and the stream [11] leaving the cyclone consists of noncondensible gases, water vapor, pyrolysis oil vapor, and some char fines. This mixture enters the condenser, and the pyrolys is vapors (and some water vapor) are condensed in the air-cooled condenser. The condenser phases [12] are removed via sumps and collection receivers, and the exiting mixture [13] consisting of noncondensible gases, water vapor, light oil vapors, and aerosol of oil enter the demister. In the demister most of the aerosol is removed [14]. The resulting mixture [15], consisting mainly of noncondensible gases, water vapor, and some aerosol, enters the flare where air is introduced, the mixture is burned, and the products of combustion. [16] are exhausted to the atmosphere.

This entrained-flow pyrolysis reactor was operated with a temperature profile which ranged from $477^{\circ} \mathrm{C}$ down to $424^{\circ} \mathrm{C}$ over the length of the 


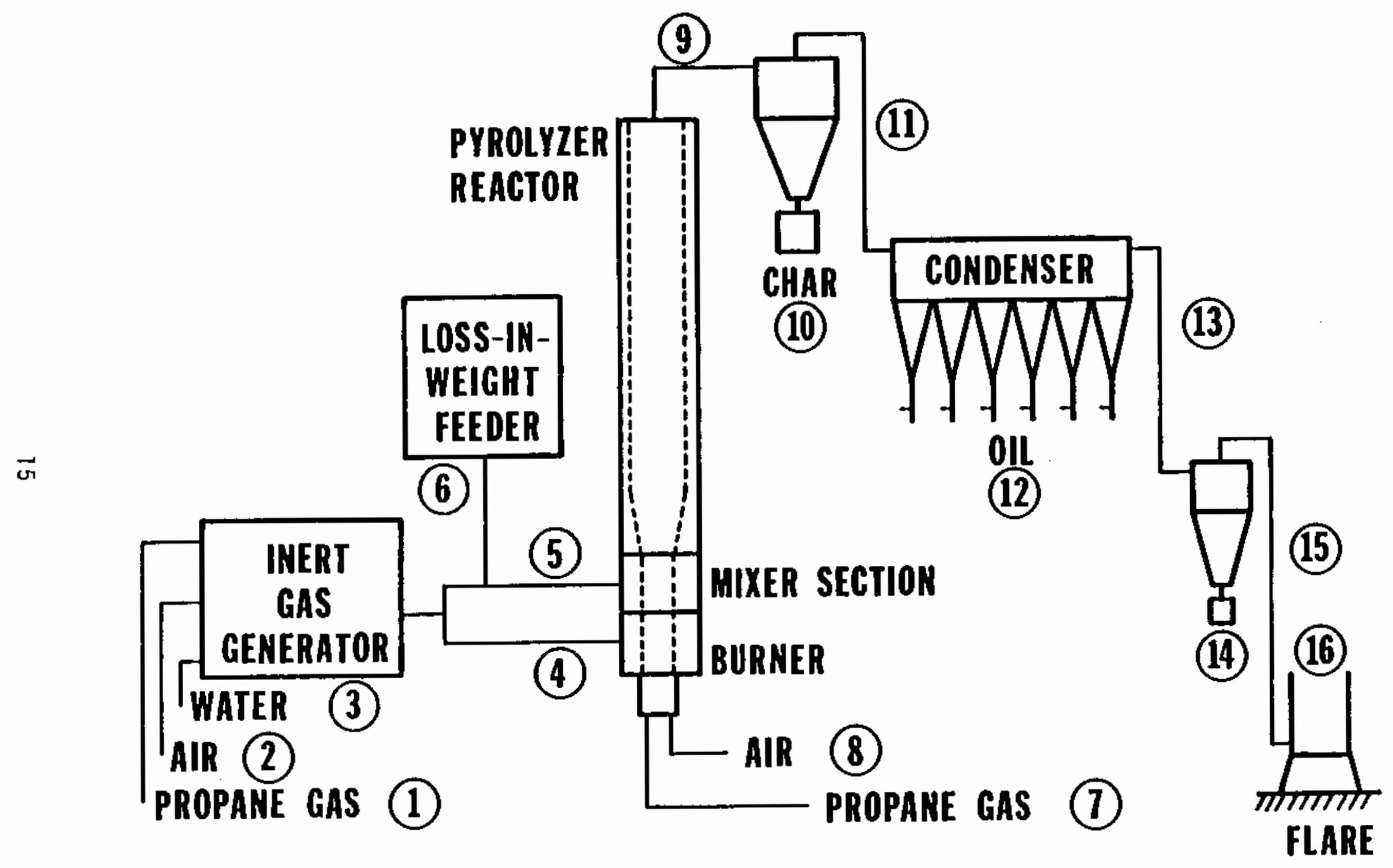

Figure 1. Georgia Tech Entrained Flow Pyrolysis Research Unit. 
reactor. The vapors then passed through the char cyclone wherein the temperature dropped to $399^{\circ} \mathrm{C}$, and then through the series of condensers so that the outlet temperature was $63^{\circ} \mathrm{C}$. Despite this cooling the final demister still captured about half the liquid product. The feedstock was ground oak, $40 \times 50$ mesh, $5.58 \%$ moisture, $0.42 \%$ ash, fed at $113.2 \mathrm{lb} / \mathrm{hr}$.

The product fractions were collected separately from each of the condensers and the demister; they varied in consistency from liquids to tars to solids. The composite sample analyzed in this program was prepared by mixing the product fractions in proportion to the amount of each fraction produced during the test. A homogeneous sample was obtained since the liquid fractions were miscible and the solid fractions were soluble in the liqud fractions.

SERI Entrained-Flow, Fast Ablative Pyrolysis (39)

A diagram of the experimental unit is provided in Figure 2. In operation, the biomass is loaded into the feed hopper and then dried in nitrogen or air passing through the pyrolysis reactor, up through the bottom of the hopper. and out near the top. This serves both to dry the feed as well as to preheat it to a temperature above the dew point of steam $\left(>98^{\circ} \mathrm{C}\right)$ in Golden, $\mathrm{Co}$. This preheating eliminates the need for a carrier gas in addition to steam because the steam will not condense on the hot material during the run. The $45 \mathrm{~mm}$ diameter open flight (i.e., corkscrew), single auger is used for feeding large particles such as wood chips, whereas, the interchangeable set of twin $35 \mathrm{~mm}$ screws are designed to feed fine powders without flooding.

After the feed preheating step, the heater temperatures are increased to that desired for pyrolysis operation. The pyrolysis system is then purged with nitrogen to avoid having combustible mixtures present in the system during startup. The gravimetric weigh feeder and the boiler are set to produce the desired mass flow rates of biomass feed and steam respectively (a nominal $50 \mathrm{~kg} / \mathrm{hr}$ of each). The supersonic, entraining steam flow is established and only then is the biomass feeding begun. The steam serves to entrain the biomass into the reactor at high velocities, to produce the positive pressure needed for gases to flow through the system, and to dilute the prinary pyrolysis products which reduces their tendency toward molecule building, bi-molecular reactions.

The entrained biomass particles enter tangentially into the 14 cri diameter by $70 \mathrm{~cm}$ long cyclonic pyrolysis reactor so that the particles are centrifuged against the red hot, externally heated Incoloy $800 \mathrm{H}$ walls held at temperatures as high as $1000^{\circ} \mathrm{C}$. The entering velocities will average about $100 \mathrm{~m} / \mathrm{s}$ for the entraining steam and probably somewhat lower for the still accelerating biomass particles. As the particles slide on the inside of the cyclonic pyrolys is reactor, they are expected to be heated almost entirely by a solid convective heat transfer mechanism. This causes an extremely rapid, ablative pyrolys is to occur at the interface of the biomass particle and the reactor wall. The biomass decomposes to a Tow viscosity oil or to vapors at the interface. The pyrolytic oit left on the reactor wall will vaporize before decomposing to char if the reactor walls are maintained at a high enough temperature. The pyrolytic oil vapors are then free to leave the cyclonic pyrolysis reactor surface and enter the vapor cracking tube. The cyclonic reactor is electrically heated by three independent heaters. The cycionic 


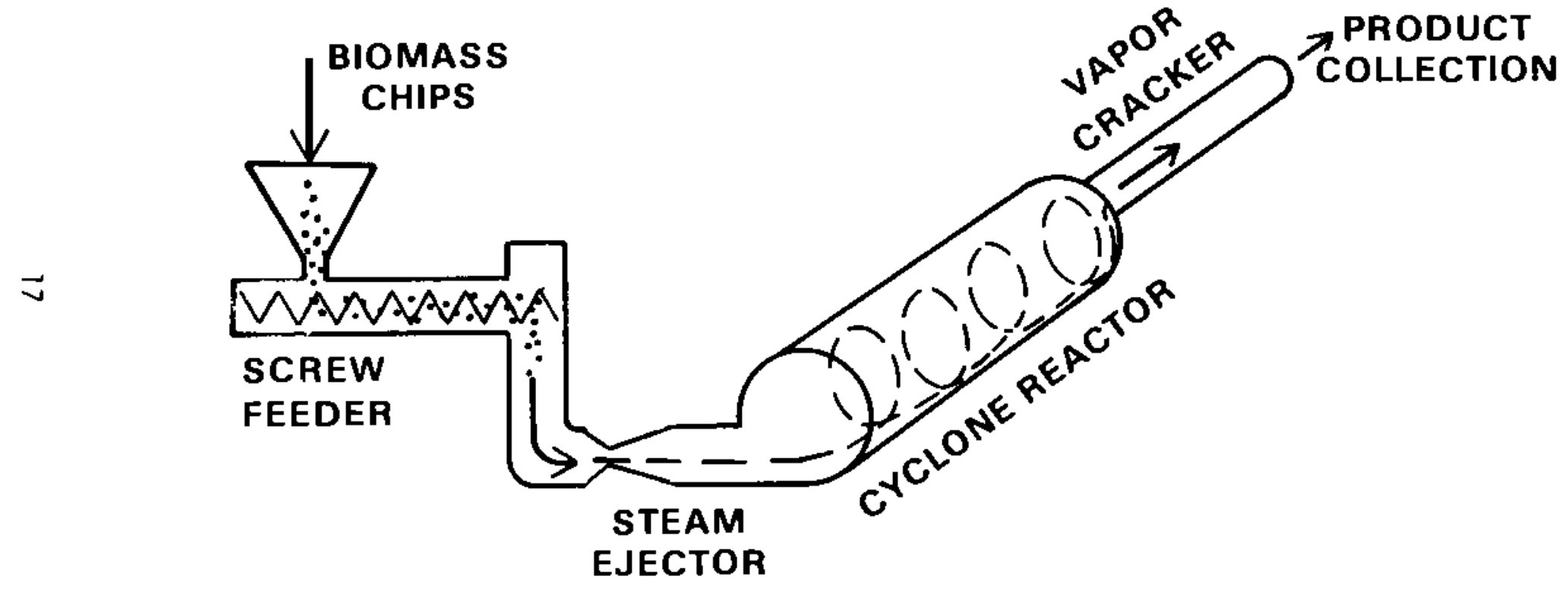

Figure 2. SERI Ablative Pyrolysis System. 
action of the reactor prevents the unpyrolyzed particles from escaping with the steam and oil vapors and any unreacted particles will pass out of the cyclone through a tangential escape tube located near the vapor outlet.

The $6.4 \mathrm{~m}$ long by $5 \mathrm{~cm}$ diameter vapor cracking tube is made of Incoloy 800 $\mathrm{H}$ so that the wall temperature can be held as high as $1000^{\circ} \mathrm{C}$ without adverse effects. Its function is to futher pyrolyze the tar vapors from the pyroiysis reactor to gases containing the desirable olefins such as ethylene. The vapor cracker has seven evenly spaced thermowells and six independentiy heated sections. The clam shell electric heaters are banded together with stainless steel straps. The heaters rest on high temperature insulating bricks ( $\mathrm{K}-23$ or $\mathrm{K}-26$; Babcock and $\mathrm{Wilcox}$ ) and are covered with four $2 \mathrm{~cm}$ thick layers of ceramic fiber blankets (Cerafeit; John Mansville).

After passing through the vapor cracker, the pyrolysis products enter the first scrubber system which is the $38 \mathrm{~cm}$ diameter cyclonic scrubber. The hot gaseous products enter tangentially into the cyclonic quench drum at a nominal $50 \mathrm{~m} / \mathrm{sec}$. Cooled water is sprayed across the gas flow to quench the chemical reactions, to condense the tar vapors, and to scrub the condensates out of the gas stream.

The cooled gas stream (at about $77^{\circ} \mathrm{C}$ ) then passes to the packed scrubber where it will flow upward counter-currently to the cool, descending scrubbing water. The bottom $0.5 \mathrm{~m}$ of this scrubber is packed with $1 \mathrm{~cm}$ ceramic Ber $]$ Saddles. Most of the entrained condensates from the cyclonic scrubber and the condensing heavier oil vapors will be retained on this bed of large particles. Above the ceramic packing are about $1.5 \mathrm{~m}$ of a packed bed made up of fhort lengths of plastic packing resembling bottle brushes. This BrushPac ${ }^{\prime}$ is used to remove the very fine particles from the gas stream. As the temperature of the pyrolysis gas and steam mixture decreases, progressively more steam and volatile organics will condense. The condensing of the steam and organic volatiles will aid in the coalescing of the expected fine mists of water and tar droplets. The cooled gases then pass through an orifice meter before being compressed for storage or being sent to the flare for incineration. The condensed steam and organic volatiles are available for make-up water to the cyclonic scrubber, as needed, but are primarily pumped to the flare for incineration.

For pyrolysis tar production the unit was operated at relatively low temperatures. The entraining dry nitrogen was at $515^{\circ}$ to $520^{\circ} \mathrm{C}$ and 75 psia prior to expansion in the supersonic steam ejector. The cyclonic reactor was operated with a wall temperature of $600^{\circ}$ to $620^{\circ} \mathrm{C}$ and a vapor exit temperature of $480^{\circ}$ to $485^{\circ} \mathrm{C}$. The temperature dropped to $400^{\circ} \mathrm{C}$ during passage through the vapor cracker tube. The vapors then passed through cyclones before being collected in a packed scrubber which was water cooled on its outside wall. The cracked tar product was recovered following a similar operation in which a steam ejector operating at $750^{\circ} \mathrm{C}$ and $143 \mathrm{psia}$ was used to entrain the biomass in cyclonic reactor. The inlet stream temperature for the cyclonic reactor was $530^{\circ}-535^{\circ} \mathrm{C}$ while the wall temperature was held at $625^{\circ} \mathrm{C}$. The exit stream passed through the char cyclone prior to entering the vapor cracker tube. The inlet stream temperature for the vapor cracker was $525^{\circ} \mathrm{C}$ while the six zone heaters on the vapor cracker were set at $750^{\circ} \mathrm{C}$. The production stream reached this temperature after passing through $1 / 3$ of the reactor and total residence time in the cracker was 0.3 seconds. The tar was recovered in the water spray 
cyclone scrubber. The feedstock for both tests was a dry, $-3 / 16$ inch softwood sawdust. The effect of the difference in the use of nitrogen as entraining gas in one case and steam in another is unknown at this time and should be considered further.

\section{UPDRAFT GASIFICATION}

The only updraft gasifier samples in this program were recovered from the Georgia Forestry Commission gasifier at the Northwest Georgia Regiona? Hospital in Rome, GA. The Appiied Engineering Company woodchip gasifier which was built at Rome, GA, is a fixed bed updraft gasifier depicted in Figure 3. The reactor vessel is a heavy wall steel shell lined with refractory and incorporates a water jacket surrounding the grate region. The grate serves the dual purpose of uniformly injecting air into the reactor vessel and breaking up any clinkers that the gasification reaction might produce. Ash may be removed from the vessel while the unit is in operation (40). The inside dimensions of the reactor are 16 feet high and 10 feet in diameter with a typical bed height of 10 feet.

The gasification process begins with the even distribution of green wood chips over the top of the bed. The chips progress downward, counter to the flow of produced gas, and pass through zones of drying, pyrolysis, reduction and oxidation, the gasifier currently pipes product gas and condensates to a retrofitted fire tube boiler where they are cleanly and completely combusted. The condensate sample was removed from a settling tank in the offgas piping. Although the temperature profile of the bed is unknown, the combustion zone contains temperatures of $1370^{\circ}-1650^{\circ} \mathrm{C}$ and the product gas and condensibles leave the top of the gasifier at $93^{\circ} \mathrm{C}$. TypicalTy, the gasifier feed is 1 1/2 ton/hr of whole tree chips (mostly hardwood, but some pine) with a moisture content of 50 percent which produces $19,000 \mathrm{lb} / \mathrm{hr}$ of steam in the boiTer by combustion of the $150 \mathrm{BTU} / \mathrm{SOCF}$ product gas.

\section{DOWNDRAFT GASIFICATION}

Four downdraft gasifiers were sampled in this program. Three of the gasifiers are close-coupled with internal combustion engines while the SERI unit is a research unit used to model bionass gasification.

\section{SERI Stratified Downdraft Gasification (41a)}

The SERI stratified downdraft research scale gasifier is depicted in Figure 4. In the stratified system both biomass and air or oxygen enter the top of the reactor together; there are no air injection ports within the bed. As a result, a recognizeable series of distinct reaction zones develops within the bed and hot spots around the air injection nozzles are eliminated. The research scale reactor is fabricated from $9 \mathrm{~cm}$ I.D. quartz tube $30 \mathrm{~cm}$ long and insulated with a second pyrex tube with a microscopic layer of gold deposited on it. The two tubes are separated by a $3 \mathrm{~mm}$ air space. The condensate sample was collected from the gas product following the heat exchanger.

The sample analyzed from SERI included the condensate for an entire experimental test run. As such, it was condensate produced over a broad range of conditions including feed rate, oxygen/fuel ratio and reactor 


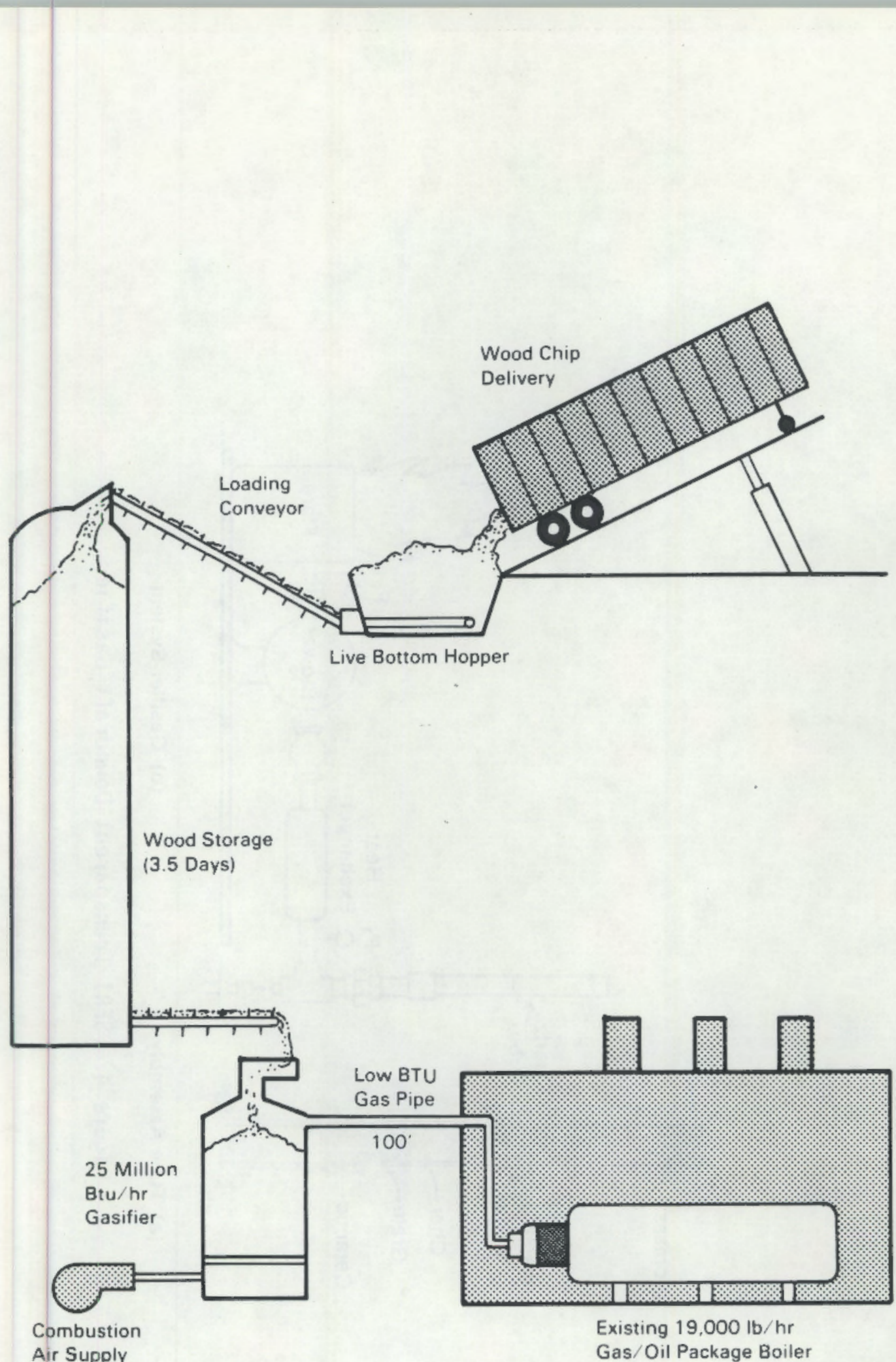

Figure 3. Updraft Woodch ip Gas if ication System at Rome, Georgia. 


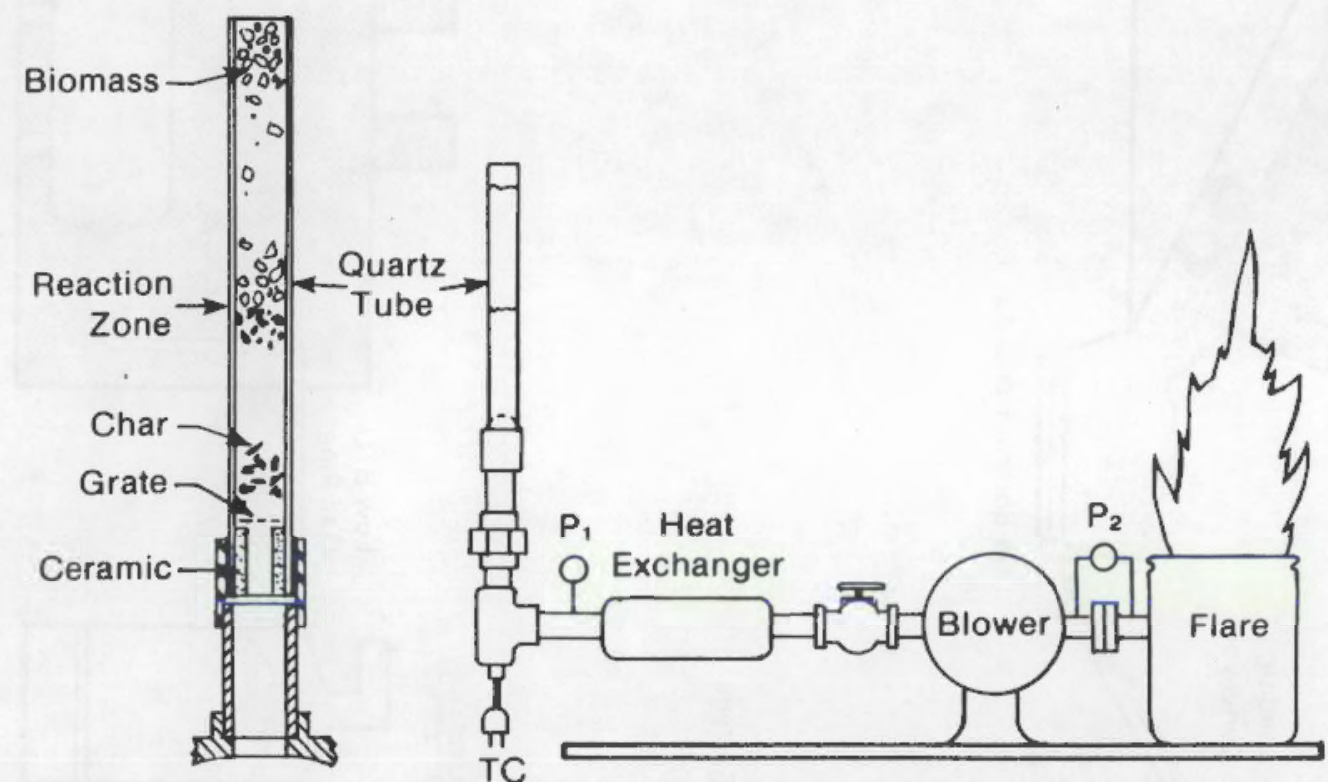

(a) Tube Assembly

(b) Gasifier System

Figure 4. SERI Transparent Downdraft Gasifier. 
temperatures. The operation range extended from $400^{\circ}-500^{\circ} \mathrm{C}$ up to $680^{\circ}-1000^{\circ} \mathrm{C}$ in the reactor bed with reactions varying from near pyrolys is to nearly pure combustion. The feedstock for the test was dry birch dowels fed at 2-4

$\mathrm{lb} / \mathrm{hr}$. A bed height of 4-10 cm was maintained during the test. Air was used to blow the gasifier.

\section{Cal Recovery Systems Biomass Gasification(42)}

The system consists of a thermal reactor, a gas cooling and cleaning (GCC) train, and a diesel engine. The configuration of the system is shown schematically in Figure 5. As shown in the figure, either ambient air or compressed air can be supplied to the gasifier. The gasifier is of the downdraft type with provisions for batch loading of fuel and for ash removal. It consists of a 55-gallon drum lined with refractory. The reactor has a reaction zone (and hence fuel bed) of approximately 3.5 cubic feet. The dimensions of the zone are about 16 inches in diameter and 30 inches in depth. Located approximately in the center of the reaction zone is an adjustable air distributor which can be used to augment air flow to the center of the reaction zone or to control the geometry of the combustion zone. At the bottom of the gasifier is the grate which supports the fuel bed.

The design chosen for the GCC train was based upon a conservative design for two reasons. First, the program calls for operating the gasifier/engine system in an indoor laboratory facility. Secondly, to preserve the research engines, a clean producer gas is desirable if not mandatory. The GCC train consists of an integral wet scrubber and sieve plate unit. As a precaution, a cloth filter is located downstream of the GCC unit.

Two condensate samples from the GCC train were analyzed in this program representing operations with walnut shells and refuse-derived fuel (RDF). The reduction zone was at $540^{\circ} \mathrm{C}$ and $510^{\circ} \mathrm{C}$ while the combustion zone was at $730^{\circ} \mathrm{C}$ and $700^{\circ} \mathrm{C}$ for the walnut shells and the RDF respectively. Both tests were air-blown. The product gas stream entered the GCC train at $200^{\circ}$ and $170^{\circ} \mathrm{C}$ for the two respective fuels and exited the GCC train at approximately $25^{\circ} \mathrm{C}$. The walnut shells were fed at $8.8 \mathrm{~kg} / \mathrm{hr}$ while the RDF was fed at $6.0 \mathrm{~kg} / \mathrm{hr}$; the airflow was 8.1 and $6.8 \mathrm{~m} / \mathrm{hr}$ for the walnut shells and RDF, respectively.

\section{University of Florida Biomass Gasification(55)}

Smal1 downdraft gasifiers are being used at the University of Florida to drive several types of small engines. The gasifiers are all basically the same and are based on designs from the National Machinery Testing Institute of Sweden. The gasifier, shown schematically in Figure 6 , has a $31.8 \mathrm{~cm}$ diameter within the seven air tuyeres. It includes a condensate trap around the outside of the drying zone into which moisture and some organic volatiles are collected during operation. This condensate is the sample analyzed in this program. The feedstock for these tests was $1.5 \mathrm{~cm}$ citrus chips with 12-15\% moisture. No measurements of the bed temperature or the product gas flow are available. The gasifiers are fabricated of mild steel and typical dimensions are given in Figure 6. 


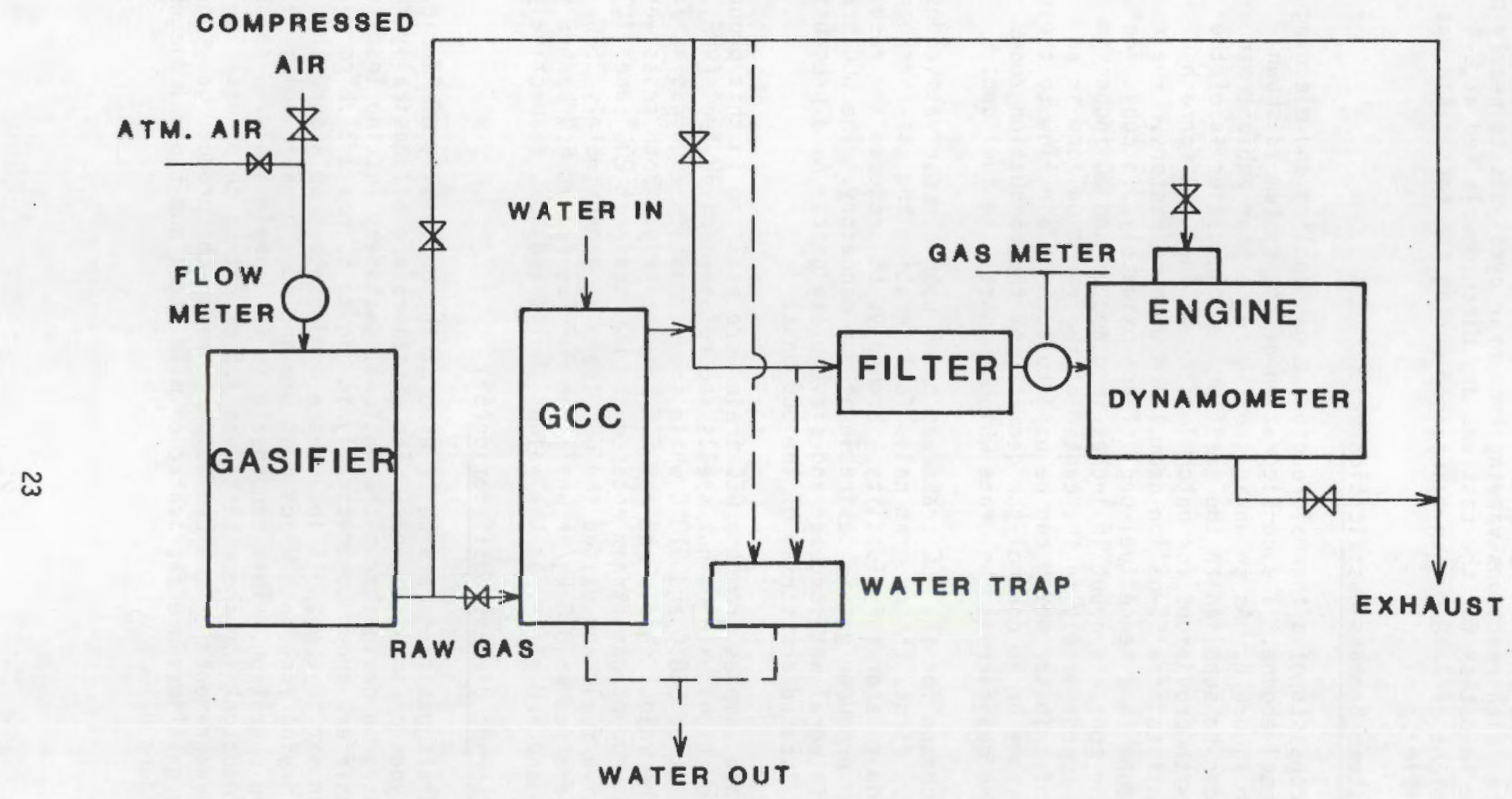

Figure 5. Cal Recovery Systems Experimental Gasification System. 


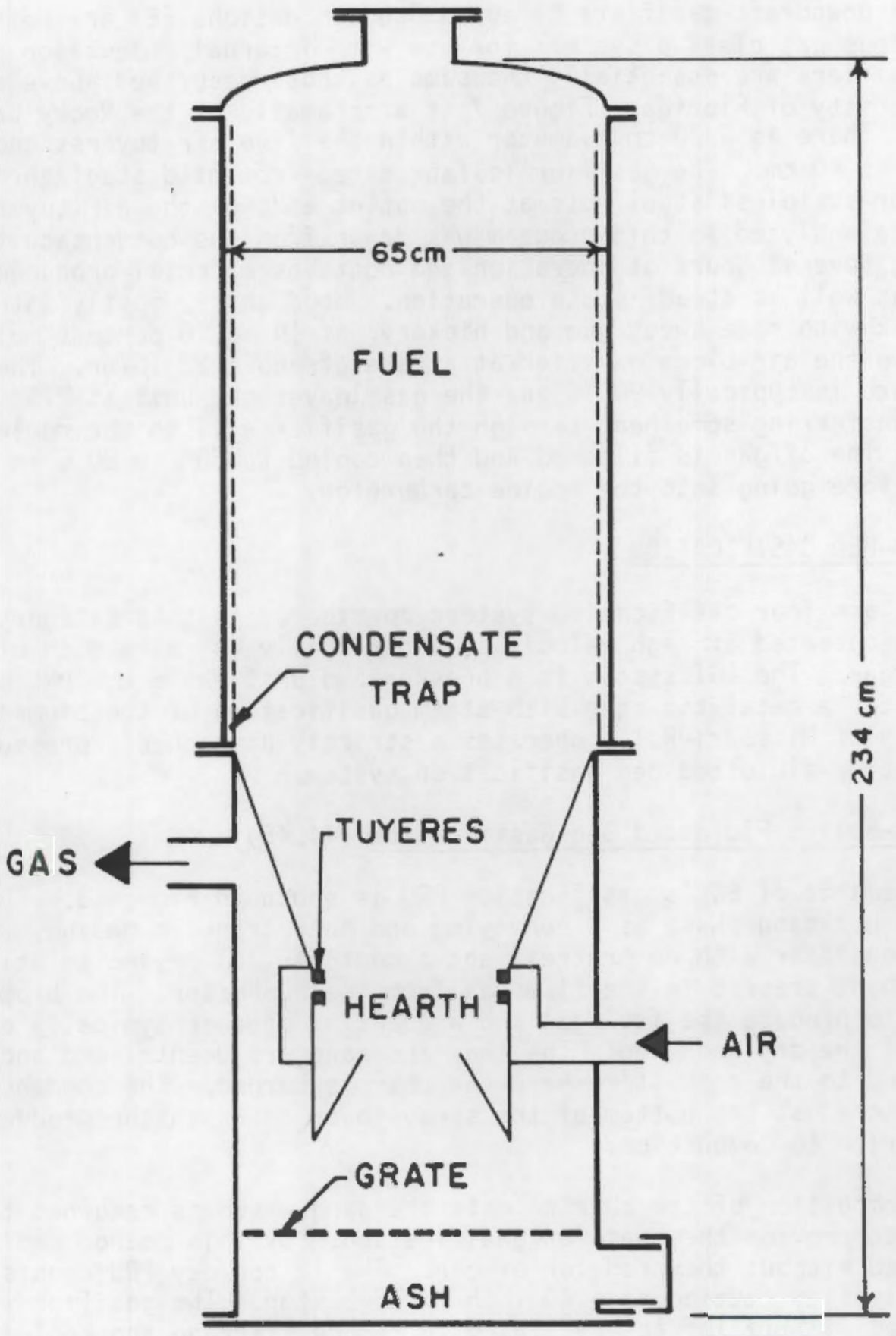

Figure 6. Cross-Sectional View of Downdraft Gasifier Used by the University of Florida. 


\section{Rocky Creek Farm Gasogens (1)}

Small downdraft gasifiers based on Swedish designs ( 8 ) are being tested with various gas cleanup systems for use with internal combustion engines. These gasifiers are essentially the same as those described above in use at the University of Florida. Figure 7 is a schematic of the Rocky Creek Gasogen. There is a $20 \mathrm{~cm}$ diameter within the five air tuyeres and the bed diameter is $40 \mathrm{~cm}$. The gasifier is fabricated from mild steel throughout except for stainless steel nuts at the outlet ends of the air tuyeres. The condensate analyzed in this program was drawn from the condensate trap following several hours of operation and contains material produced during startup as well as steady state operation. Wood chips, mostly water oak and laurel oak with some sweet gum and hickory, at 14 to 16 percent moisture, are charged to the air-blown gasifier at a rate of about $32 \mathrm{lb} / \mathrm{hr}$. The hearth temperature is typica 11 y $900^{\circ} \mathrm{C}$ and the gas leaves the unit at $275^{\circ}$ to $325^{\circ} \mathrm{C}$ after transferring some heat through the gasifier wall to the cooler bed of biomass. The offgas is filtered and then cooled to $60^{\circ}$ to $80^{\circ} \mathrm{C}$ in the filter system before going into the engine carburetor.

\section{$\underline{\text { FLUIDIZED-BED GASIFICATION }}$}

There are four gasification systems considered in this category. The $\mathrm{BCL}$ system is operated at high velocities and actually entrains much of the bed with the gas. The IGT system is a pressurized unit while the PNL system incorporates a catalytic step with steam gasification of the biomass. The University of Missouri-Rolla operates a strictly atmospheric pressure, noncatalytic, fluidized bed gasification system.

\section{BCL Multi-Solids Fluidized Bed Gasification $(44,45)$}

A schenatic of BCL's gasification PRU is shown in Figure 8. The process employs a hot sand phase as a conveying and heat transfer medium. Wood is fed into the gasifier with no pretreatment except partial drying to utilize sensible heat present in the flue gas from the combustor. The biomass is gasified to produce the fuel gas and a quantity of char typically equal to 20 percent of the dry wood fed. The char and sand are deentrained and transferred to the combustor where the char is burned. The condensate samples were collected at the bottom of the spray tower in which the product gas is cleaned prior to combustion.

The combustion of the char reheats the sand which is returned to the gasifier to provide the heat for gasification. By this method medium BTU gas is produced without the need for oxygen. The 12 ton/day PRU consists of a 10 inch ID gasifier coupled to a 40 inch ID combustor. The gasifier was constructed without refractory lining to reduce start-up and cool-down time as well as the time required to reach steady-state conditions. The gasifier was designed to operate at up to $870^{\circ} \mathrm{C}$ and $5 \mathrm{psig.} \mathrm{The} \mathrm{nominal} \mathrm{gas} \mathrm{velocity} \mathrm{is} 20$ $\mathrm{ft} / \mathrm{sec}$, which gives a gas residence time of about one second in the $20 \mathrm{ft}$, long reactor. The combustor operates at temperatures around $1040^{\circ} \mathrm{C}$.

The samples analyzed in this program are from three separate tests. The two tar samples were produced at $900^{\circ} \mathrm{C}$ and $880^{\circ} \mathrm{C}$ with oak and pine respectively (each feed was $5 \%$ moisture). The wood feed rates were $339 \mathrm{lb} / \mathrm{hr}$ and $469 \mathrm{lb} / \mathrm{hr}$ for the two feedstock respectively; in both-tests the steam feed 


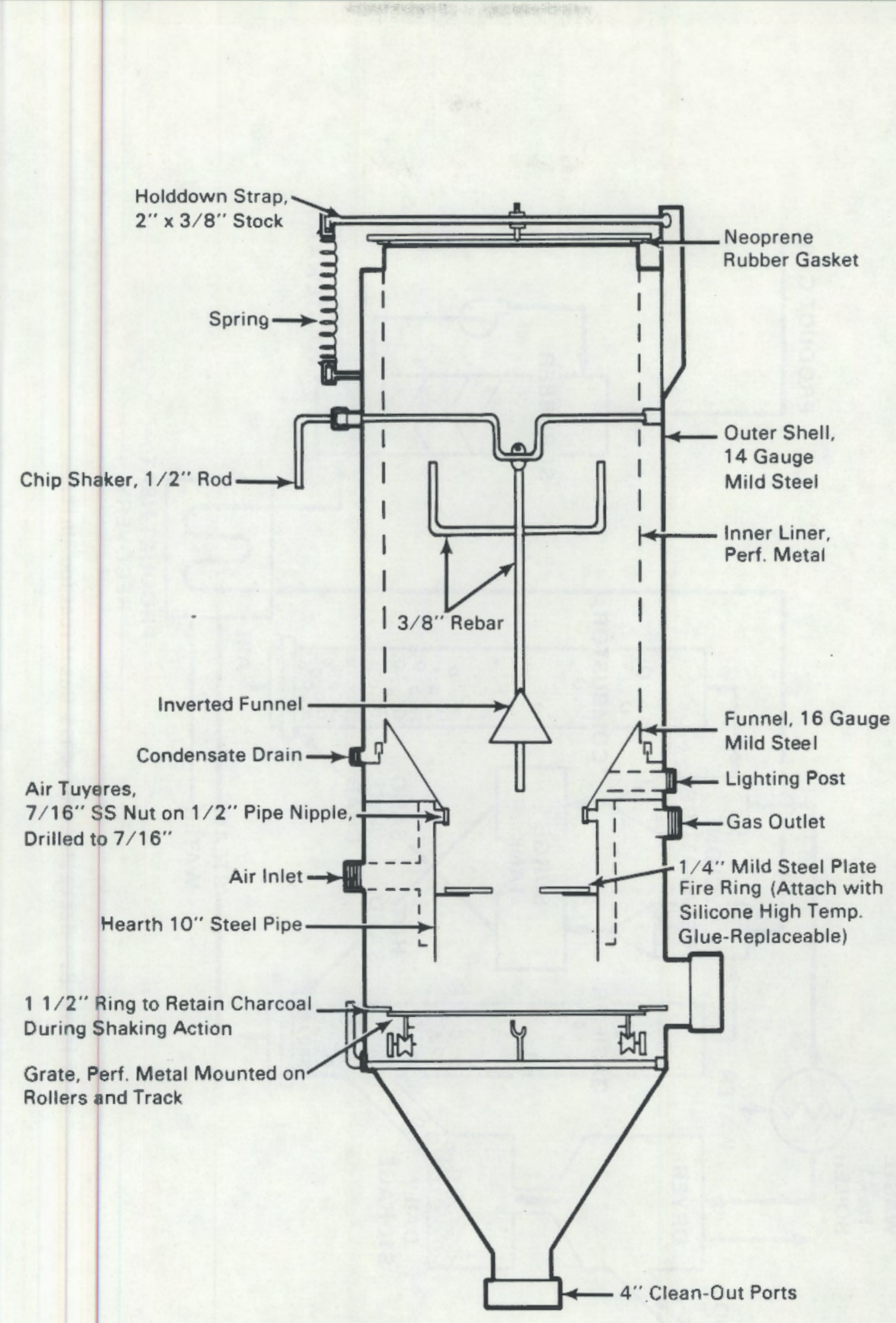

Figure 7. Rocky Creek Gasogens Gasifier. 


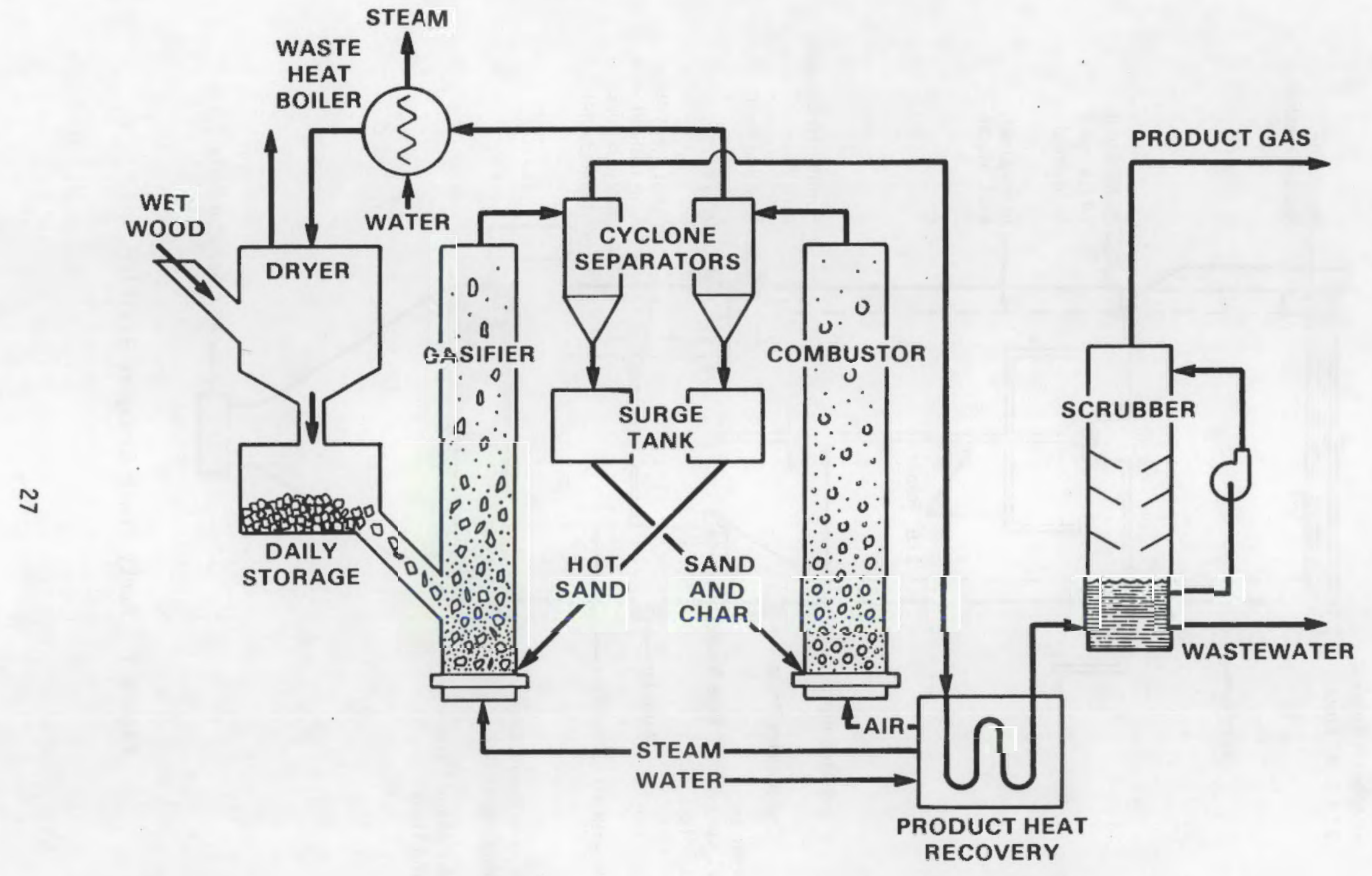

Figure 8. Battelle's Biomass Gasification Unit. 
was $440 \mathrm{lb} / \mathrm{hr}$. Nitrogen feed was $92.8 \mathrm{lb} / \mathrm{hr}$ and $78.0 \mathrm{lb} / \mathrm{hr}$ resulting in a gas velocity of $16.4 \mathrm{ft} / \mathrm{sec}$ and $15.5 \mathrm{ft} / \mathrm{sec}$ for the two feed stocks

respectively. The aqueous condensate was produced in a test at $930^{\circ} \mathrm{C}$ with no stear feed. The pine feedstock (5\% moisture) was fed at $380 \mathrm{lb} / \mathrm{hr}$ with nitrogen at $89.8 \mathrm{lb} / \mathrm{hr}$ without the steam feed, the superficial gas velocity was only $1.53 \mathrm{ft} / \mathrm{sec}$ based on the nitrogen. This test was also performed at 10 psig instead of the nominal 5 psig. The difference in operation with and without steam is unclear at this time.

IGT Pressurized Biomass Gasification

In the IGT PRU system, as shown in Figure 9, the feed hopper and the associated solids handling equipment are designed for continuous feeding to the fluidized-bed gasifier. At the top of the continuously pressurized feed hopper is a two foot ID by six foot high lockhopper, equipped with quickopening and closing gate valves and the provision for cyclic pressurization and depressurization with nitrogen. The feed hopper is 4 feet in diameter, 9 feet high, and equipped with a multiple-screw, live bottom, which meters and discharges the biomass material into the gasifier injector screw feeder. The lockhopper, valves, and feed hopper are designed for an operating pressure up to 500 psig and are capable of continuously feeding pulpwood-chip-size biomass up to $1500 \mathrm{lb} / \mathrm{h}$.

The single-stage, fluidized-bed gasifier is a three foot 00,22 foot high pressure vessel enclosing a 11.5 inch ID internal metal sleeve. It is well insulated for adiabatic operation at temperatures and pressures up to $980^{\circ} \mathrm{C}$ and 500 psig. The gasification zone is confined within a 11.5 inch ID, Incoloy $800 \mathrm{H}$, balanced-pressure reactor liner, which is surrounded by one foot of low-thermal-conductivity fiber insulation. The enclosing three foot $O D$ carbon steel pressure vessel is equipped with two horizontal six inch pipe nozzle positions about two feet apart for introducing the feed biomass materials. The total internal height of the gasifier is about 21 feet, with ten feet for the reaction zone at the bottom and eleven feet for an enlarged 1.5 foot diameter solids disengaging zone. The gasifier bottom closure flange has provisions for introducing the fluidization and gasification medium (steam and oxygen), a support lance for thermocouples and fluidized-bed differential pressure probes and a solids drain. Two fluidizing gas distributors are provided. One distributor is exclusively for steam and is positioned under the other to maintain fluidization around the steam-oxygen distributor. This eliminates the formation of a zone of stationary solids near the steam-oxygen distributor, reducing the exposure of the solids to possible sintering conditions.

The solids receiver vessel is a three foot ID, six foot high, carbon-steel pressure vessel. It is refractory lined to withstand hot raw gases. It functions as a hot, pressurized filter and contains three removable trays filled with a filter mediun of pebbles or layers of stainless steel wool to trap the particles entrained with the raw gas stream. The filter media and baskets are weighed before and after each run to estimate solids carryover and the collected solids samples are analyzed chemically.

The piping between the gasifier and the solids receiver and between the solids receiver and the water spray quench line is also refractory-lined carbon-steel pipe. Partial quenching with water is done in the solids 


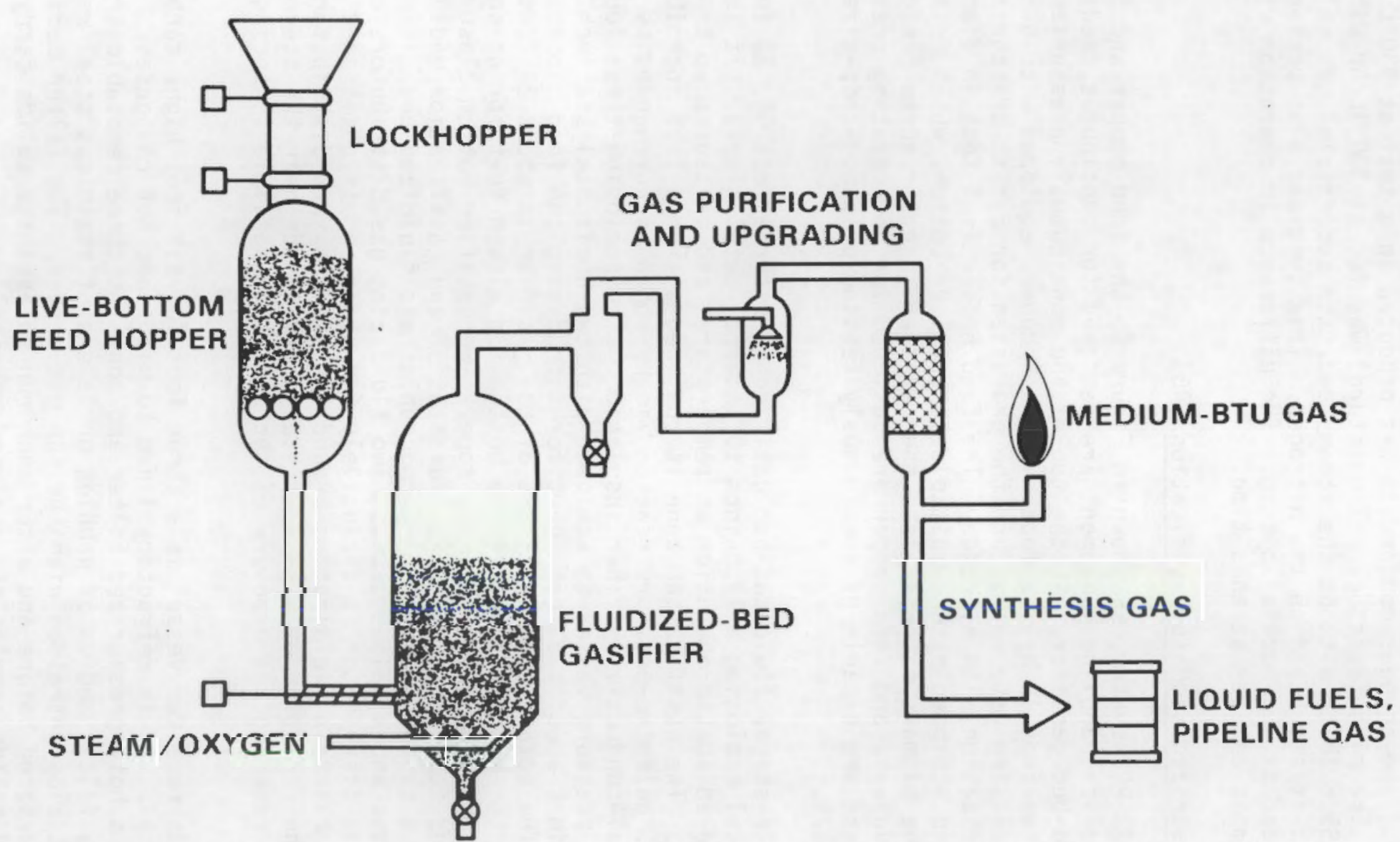

Figure 9. IGT Process Research Gasifier. 
receiver and the quench tower just to cool the gases, avoiding liquid condensation, so that carbon steel pipe can be used to pipe the product gases to a flare for disposa1. In order to analyze condensate from the product gas, an isokinetic probe recovers a slip stream of approximately $1 \%$ of the product gas from the top of the reactor.

The sample analyzed in this program was produced at a gasifier bed temperature of $816^{\circ} \mathrm{C}$ while operating at 300 psig. The maple wood feedstock was fed at $693.5 \mathrm{lb} / \mathrm{hr}$ with $0.86 \mathrm{lb}$ steam/1b feed and $0.25 \mathrm{lb}$ oxygen/lb feed. The dry raw gas flow rate was 132.6 SCFH with the nitrogen purge amounting to about $20 \%$ by volume of the raw gas. Inert solids (alumina) were present in the bed.

\section{PNL Catalytic Steam Gasification ${ }^{*}$}

The system which was sampled for this program is a bench-scale unit designed to identify catalysts, conditions and equipment arrangements for catalytic steam gasification. The reactor is made with a three inch, schedule 40, stainless steel pipe fluidized-bed section and a five inch schedule 40 , stainless steel pipe disengaging section. Overall length of the reactor is six feet with a one foot fluidized-bed section. A schematic of the reactor and wood-feed section is shown in Figure 10 . Wood is metered into the inlet line ( $1 / 2$ inch tubing) where it is entrained by steam and nitrogen and carried into the fluidized bed of char and sand or bauxite. No distributor plate is needed. The wood feed column is made from 8 inch I.D. plexiglass pipe and contains a wood supply adequate for an entire test. The auger feed system has been calibrated and delivers wood at rates from $1 / 2$ to $10 \mathrm{~kg} / \mathrm{hr}$. Furnaces for the reactor and second catalyst vessel can be operated at temperatures up to $1200^{\circ} \mathrm{C}$. The condensate sample is taken from the knockout pot following the main condenser.

For the particular test sampled, the gasifier temperature was $780^{\circ} \mathrm{C}$ and the secondary catalyst bed was at $750^{\circ} \mathrm{C}$. Sand was used as the inert bed material and the secondary bed catalyst was nickel metal on an alumina support. The densified pine flake feedstock was fed in a 1 to 1 mass ratio with steam. The sample is representative of condensate produced with an active catalyst.

* This information is courtesy of E. G. Baker, L. K. Mudge and M. D. Brown of Pacific Northwest Laboratory.

University of Missouri-Rolla Fire Tube Gasification System

The entire gasifier system is shown in Figure 11. The steam is supplied by a 45 horsepower low pressure boiler. The output steam is superheated up to $650^{\circ} \mathrm{C}$ using the $178-\mathrm{Kw}$ electrical preheater. The wood is stored in a large bin which supplies a weigh barrel. The weighed feed is dumped into the feed hopper which augers the dry wood into the bed of the reactor. The resulting gas passes through the cyclone for char removal and is piped to the flare.

The reactor is a 20 inch I.D. and 17 feet high stainless steel cylinder with several access ports. The feed ports were constructed to provide tangential feed entry. A special design was required at the top of the reactor to permit fastening of the wires used for supporting the fire tubes. 


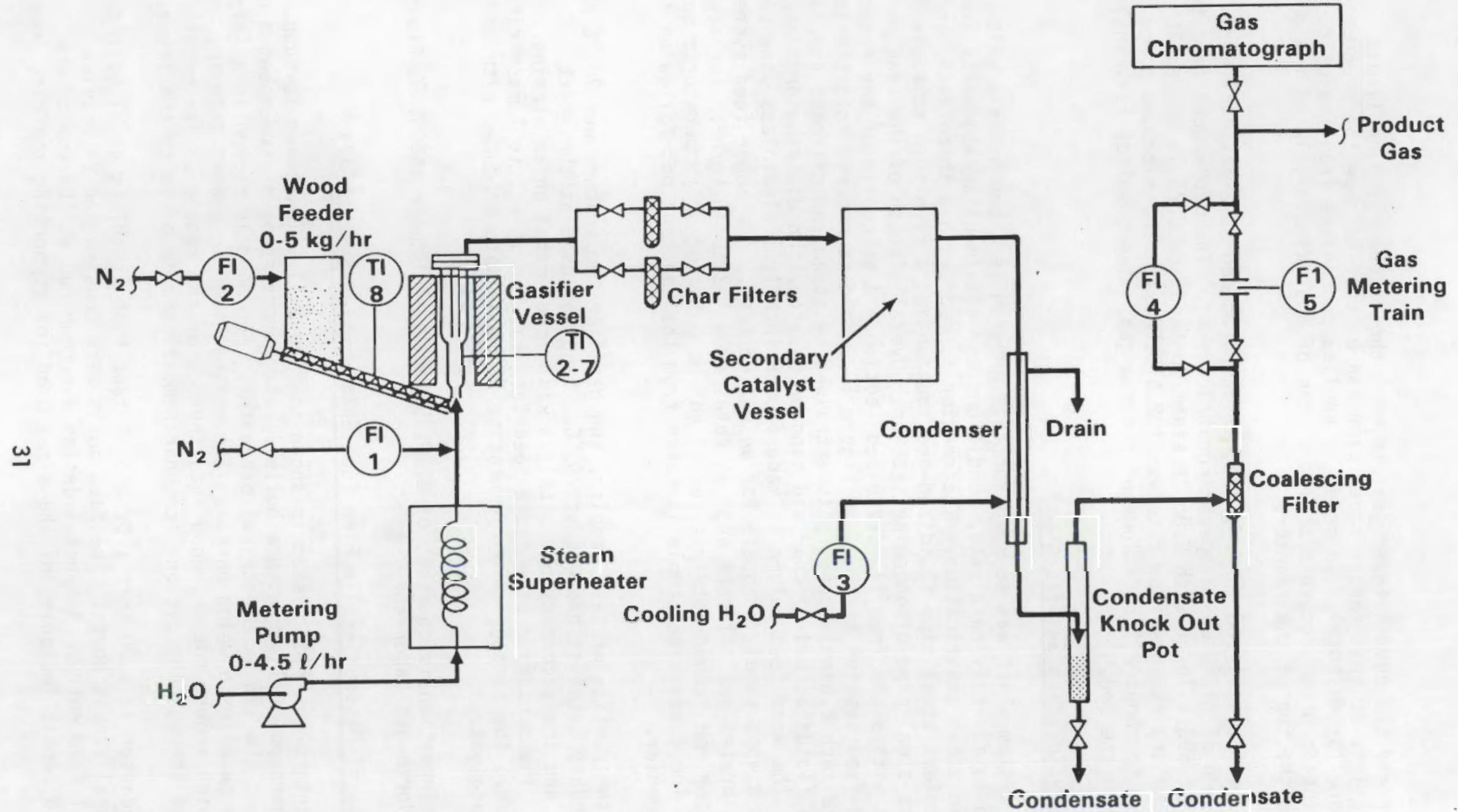

Figure 10. PNL Bench-Scale Gasification Equipment. 


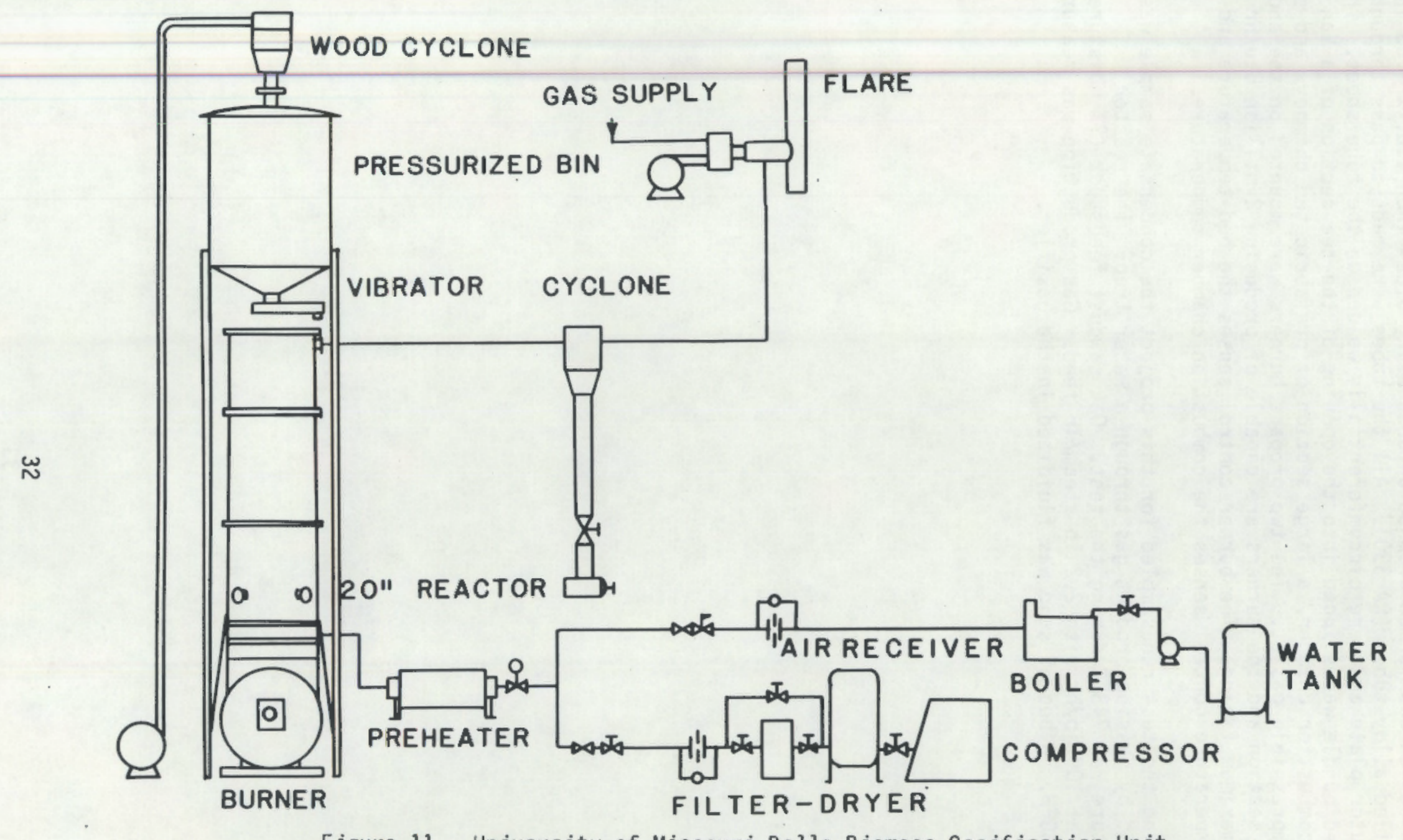

Figure 11. University of Missouri-Rolla Biomass Gasification Unit. 
The tube design was formed from 30 u-tubes using 0.824 inch I.D. $\times 1.05$ inch $0 . D$. rolled alloy tubes (RA 330 ). All the tubes were made to pass through the distributor plate and were circumferentially welded on the tube sheet. The assembled bundle was slipped into the opening of the tee section of a Van Packer combustion chamber, a large section of prefabricated chimney, and set on a compressible gasket. The two propane burners were mounted on the ends of the tee section and the burners are capable of producing $2 \mathrm{million} \mathrm{Btu} / \mathrm{hr}$ (586 $\mathrm{Kw}$ ) at maximum firing. The burner control senses the bed temperature and the over temperature control senses the combustion chamber temperature.

During the test run sampled for this project the condensate sample was collected by passing product gas through a water trap. The reactor temperature was $743^{\circ} \mathrm{C}$ during the test. Oak sawdust feedstock ( $7 \%$ moisture) was fed at $100 \mathrm{lb} / \mathrm{hr}$ with $2.2 \mathrm{lb}$ steam/1b feed. Gas production was measured at 624 SCFH. A bed of sand was fluidized in the gasifier. 


\section{ANALYTICAL RESULTS}

As a means of simplifying the presentation of these results, they are here categorized as gross compositional analysis, physical properties, specific chemical analysis and biological activity measurements. Further, within each group of analyses will be presentations of the results for the tar phases and results for the aqueous phases.

\section{GROSS COMPOSITIONAL AND PHYSICAL ANALYSIS}

Tar Phase Anatysis

The composition of the various tars analyzed in this project varies over a wide range. No average composition for gasification tars appears appropriate. Table 3 presents the compositions for the tars as measured in this project. The large amount of dissolved water found in the tars makes a second comparison of the tars on a dry basis (see Table 4) more useful when considering the composition of the organic components.

The nitrogen and sulfur contents of the tars are uniformly low. Trace contamination of iron, zinc or lead is believed to be derived from materials of construction of the PRUs or sample containers i.e. soldered, galvanized steel. The high ash content in the BCL hardwood tar is derived primarily from sand carried over due to high gas velocities. Calcium, potassium and phosporus are the primary, biomass-derived inorganic contaminants.

Table 3. Gross Compositional Analysis of Tars

\begin{tabular}{|c|c|c|c|c|c|c|c|}
\hline & $\begin{array}{l}\text { Georgia } \\
\text { Tech }\end{array}$ & $\begin{array}{l}\text { SERI } \\
\text { entrained }\end{array}$ & $\begin{array}{l}\text { Rome, } \\
\text { Georgia }\end{array}$ & $\begin{array}{l}\text { Rocky } \\
\text { Creek } \\
\end{array}$ & $\begin{array}{l}\text { BCL } \\
\text { Pine }\end{array}$ & $\begin{array}{l}\mathrm{BCL} \\
\text { Hardwood }\end{array}$ & $\begin{array}{l}\text { SERI } \\
\text { Cracked }\end{array}$ \\
\hline carbon, \% & 45.2 & 46.4 & 66.1 & 59.2 & 57.3 & 70.3 & 76.4 \\
\hline hydrogen. \% & 7.2 & 7.2 & 7.6 & 6.4 & 7.0 & 6.0 & 5.7 \\
\hline oxygen, \% & 50.7 & 48.8 & 27.3 & 32.6 & 30.7 & 21.0 & 14.9 \\
\hline nitrogen, \% & $<0.7$ & $<0.1$ & $<0.1$ & $<0.1$ & $<0.1$ & $<0.1$ & $<0.7$ \\
\hline sulfur, ppm & $<59$ & 99 & 139 & 503 & 114 & 174 & 717 \\
\hline ash, \% & 0.2 & 0.8 & 0.2 & 1.8 & T. 1 & 5.0 & 0.6 \\
\hline moisture, \% & 16.6 & 16.1 & 8.0 & 11.9 & 27.9 & 20.4 & 13.0 \\
\hline $\begin{array}{l}\text { trace } \\
\text { element, ppr }\end{array}$ & $\begin{array}{r}1030 \mathrm{Fe} \\
30 \mathrm{~K} \\
20 \mathrm{Ca}\end{array}$ & $\begin{array}{c}2270 \mathrm{Fe} \\
1950 \mathrm{Zn} \\
<250 \mathrm{Si} \\
<110 \mathrm{P} \\
80 \mathrm{~Pb}\end{array}$ & $640 \mathrm{Si}$ & $\begin{array}{r}7850 \mathrm{Fe} \\
480 \mathrm{Si} \\
<120 \mathrm{P} \\
\uparrow 10 \mathrm{Zn}\end{array}$ & $\begin{array}{l}2920 \mathrm{Si} \\
1340 \mathrm{Ca} \\
1140 \mathrm{Fe} \\
360 \mathrm{~K} \\
<190 \mathrm{P} \\
100 \mathrm{Cr}\end{array}$ & $\begin{array}{l}4670 \mathrm{Si} \\
3110 \mathrm{Ca} \\
1370 \mathrm{Fe} \\
1060 \mathrm{~K} \\
500 \mathrm{P} \\
130 \mathrm{Cr} \\
140 \mathrm{Mn} \\
110 \mathrm{Cl}\end{array}$ & $\begin{array}{r}1720 \mathrm{Ca} \\
470 \mathrm{~K} \\
269 \mathrm{Fe} \\
120 \mathrm{Mn}\end{array}$ \\
\hline
\end{tabular}


Table 4. Composition of Tars on a Ory Basis.

$\begin{array}{lccccccc} & \begin{array}{l}\text { Georgia } \\ \text { Tech }\end{array} & \begin{array}{l}\text { SERI } \\ \text { entrained }\end{array} & \begin{array}{l}\text { Rome, } \\ \text { Georgia }\end{array} & \begin{array}{l}\text { Rocky } \\ \text { Creek }\end{array} & \begin{array}{l}\text { BCL } \\ \text { Pine }\end{array} & \begin{array}{l}\text { BCL } \\ \text { Hardwood }\end{array} & \begin{array}{l}\text { SERI } \\ \text { Cracked }\end{array} \\ \text { carbon, \% } & 52.1 & 53.3 & 70.9 & 67.2 & 84.0 & 85.8 & 90.3 \\ \text { hydrogen, \% } & 6.2 & 6.2 & 7.2 & 5.8 & 5.7 & 4.5 & 5.1 \\ \text { oxygen, \% } & 41.4 & 39.6 & 21.7 & 25.0 & 8.7 & 3.5 & 3.9 \\ \begin{array}{l}\text { ash, \% } \\ \text { H/C, }\end{array} & 0.2 & 0.9 & 0.2 & 2.0 & 1.6 & 6.1 & 0.7 \\ \begin{array}{l}\text { atonic } \\ \text { ratio }\end{array} & 1.42 & 1.38 & 1.21 & 1.03 & 0.81 & 0.62 & 0.67\end{array}$

The tars show a strong variation of organic composition as a function of processing severity. The hydrogen to carbon ratio drops dramatically from the low temperature, entrained pyrolysis tars from SERI and Georgia Tech to the high temperature, entrained (cracked) tars from SERI and BCL. A curious piece of data is the high level of water found in the BCL tars. These tars which are relatively low in oxygen content and therefore polar character must contain the water as an emulsion rather than a solution.

No tar analysis is given for the PNL, IGT, or University of Missouri-Rolla gasifiers. The tar is produced in such small quantities from these gasifiers that it was not possible to determine the gross composition or physical characteristics of the tars. Chemical characterization of the organics was possible, however, as is shown in a later section of this report.

When considering the physical characteristics of the tars (see Table 5), the incorporated (dissolved/enulsified) water can significantly reduce the viscosity of the tar. The updraft tar from Rome, Georgia, is remarkable in that it displays good fluid properties with only a small amount of dissolved water. The entrained tars (Georgia Tech and SERI) appear to be in a class by themselves. Their high density contrasts with their good fluidity. Their low heating values correlate with their high oxygen contents (see Table 4). Apparently the highly oxidized organics are thermally unstable because they degrade to a solid coke at relatively low temperature. The amount of distillable tar can vary over a wide range. Several of the distillations were terminated due to 1 imitations of the heater not due to thermal degradation of tar. The thermal degradation was noted in two forms. The entrained tars actually were changed to a solid, nonmelting coke in the distillation flask. The Rocky Creek tar continued to be fluid and boil but water formation was noted at the higher temperature range, long after all the water was distilled from the tar. The distillation residues reported in Table 5 are calculated for water-free oil charged to the distillation flask.

\section{Aqueous Phase Analysis}

As with the tar phases the properties of the aqueous phases from the different gasifiers vary over a wide range (see Table 6). The variations 
Table 5. Physical Characterization of Tars.

\begin{tabular}{|c|c|c|c|c|c|c|c|}
\hline & $\begin{array}{l}\text { Georgia } \\
\text { Tech }\end{array}$ & $\begin{array}{l}\text { SERI } \\
\text { entrained }\end{array}$ & $\begin{array}{l}\text { Rome } \\
\text { Georgia }\end{array}$ & $\begin{array}{l}\text { Rocky } \\
\text { Creek } \\
\end{array}$ & $\begin{array}{l}\mathrm{BCL} \\
\text { Pine } \\
\end{array}$ & $\begin{array}{l}\mathrm{BCL} \\
\text { Hardwood }\end{array}$ & $\begin{array}{l}\text { SERI } \\
\text { Cracked }\end{array}$ \\
\hline moisture, \% & 16.6 & $16 . ?$ & 8.0 & 11.9 & 27.9 & 20.4 & 13.0 \\
\hline $\begin{array}{l}\text { pour } \\
\text { point, }{ }^{\circ} \mathrm{C}\end{array}$ & -23 & -12 & -- & -- & 13 & 13 & 53 \\
\hline $\begin{array}{l}\text { viscosity, } \\
\text { CPS }\end{array}$ & $\begin{array}{l}220 \\
@ 40^{\circ} \mathrm{C}\end{array}$ & $\begin{array}{l}1300 \\
@ 30^{\circ} \mathrm{C}\end{array}$ & $\begin{array}{l}410 \\
@ 40^{\circ} \mathrm{C}\end{array}$ & $\begin{array}{l}7500 \\
@ 78^{\circ} \mathrm{C}\end{array}$ & $\begin{array}{l}9800 \\
@ 51^{\circ} \mathrm{C}\end{array}$ & $\begin{array}{l}26800 \\
951^{\circ} \mathrm{C}\end{array}$ & $\begin{array}{l}41000 \\
@ 65^{\circ} \mathrm{C}\end{array}$ \\
\hline $\begin{array}{c}\text { density, } \\
g / m ?\end{array}$ & $\begin{array}{l}1.265 \\
@ 23^{\circ} \mathrm{C}\end{array}$ & $\begin{array}{l}1.28 \\
@ 24^{\circ} \mathrm{C}\end{array}$ & $\begin{array}{l}1.13 \\
\$ 24^{\circ} \mathrm{C}\end{array}$ & $\begin{array}{l}1.16 \\
@ 22^{\circ} \mathrm{C}\end{array}$ & $\begin{array}{l}1.138 \\
@ 22^{\circ} \mathrm{C}\end{array}$ & $\begin{array}{l}1.15 \\
@ 35^{\circ} \mathrm{C}\end{array}$ & $\begin{array}{l}1.76 \\
@ 24^{\circ} \mathrm{C}\end{array}$ \\
\hline $\mathrm{HHV}, \mathrm{Btu} / 1 \mathrm{~b}$ & 7900 & 8100 & 12600 & 10800 & 10000 & 12200 & 13650 \\
\hline $\begin{array}{c}\text { dry HHV, } \\
\mathrm{Btu} / 1 \mathrm{~b}\end{array}$ & 9500 & 9600 & 13700 & 12300 & 13900 & 15300 & 15700 \\
\hline $\begin{array}{l}\text { Distillatio } \\
\text { residue, } \%\end{array}$ & $\begin{array}{l}(a) \\
60\end{array}$ & 69 & 47 & 72 & 46 & 62 & 78 \\
\hline $\begin{array}{l}\text { final } \\
\text { temp., }{ }^{\circ} \mathrm{C}\end{array}$ & $100^{b}$ & $99^{b}$ & 259 & $204^{C}$ & 257 & 217 & 228 \\
\hline $\begin{array}{l}\text { final } \\
\text { presslre, } \\
\mathrm{mmHg}\end{array}$ & 13 & 10 & 24 & 23 & 9 & 10 & 28 \\
\hline $\begin{array}{l}\text { fina] } \\
\text { temp. }{ }^{\circ} \mathrm{C} \\
\text { Corrected } \\
\text { To Atrios- } \\
\text { pheric } \\
\text { Pressure }\end{array}$ & 221 & 227 & 392 & 331 & 423 & 370 & 354 \\
\hline $\begin{array}{l}\text { final pot } \\
\text { temp. }{ }^{\circ} \mathrm{C}\end{array}$ & $209^{b}$ & $205^{b}$ & 307 & $279^{\mathrm{C}}$ & 338 & 347 & 305 \\
\hline
\end{tabular}

\footnotetext{
a Distillation curves are in Appendix $\mathrm{A}$

b Coked

c Decomposition is evidenced by water in the condensate.

appear to be due to both the type and amount of dissolved organic material. The amount of organic contamination is dependent upon the process means of collection of the aqueous stream. The various gas quenchers, condensers and spray towers used in the PRUs may not be representative of commercial systems.
} 
The type of organic byproduct has a major impact on the amount of water contamination. In the case of entrained flow at low temperatures (Georgia Tech and SERI) the aqueous phase is entirely soluble in the tar so that no separate aqueous is recovered. The updraft gasifier (Rome. Georgia) produces a two phase condensate including a highly contaminated aqueous phase. The highly oxygenated (and therefore highly water soluble) organic components produced in the updraft system results in the high level of contamination. The condensation trap on the University of Florida downdraft gasifier also produces an aqueous stream with a relatively high organic loading. The similar condensate from the Rocky Creek downdraft gasifier is also highly contaminated with organics. The downdraft gasifiers typically produce an aqueous stream with less than one percent carbon contamination while the fluidized bed units produce an aqueous stream with less than one tenth percent carbon loading (<1000 ppm TOC). The more contaminated aqueous streams have a lower (more acidic) $\mathrm{pH}$ which indicates the presence of water-soluble organic acids. Although the more contaminated streams show increases in viscosity and density as well as being highly colored they can easily be handled in systems designed for water if proper consideration is given for the streams with corrosive potential.

\section{SPECIFIC CHEMICAL ANALYSIS}

Tar Phase Analysis

Although these tars were collected as vapor condensates they contain on Ty a fraction of truly volatile organic material. Other than light oxygenated organics (which wil] be discussed later in this report) only a minor portion of the organic components could be gas chromatographed. This lack of mobility indicates a high molecular weight and/or high polarity derived from the high oxygen content. In addition, the carbon-13 NMR spectra are of poor quality due to the low signal-to-noise ratio and baseline roll. These results have been attributed to the high molecular weight of the liquid products which would not allow true solutions to be formed. The IR and NMR spectra can be found in Appendices $B$ and $C$ while Appendix D contains the GC/MS results in tabular form. Analysis of the data in these appendices is discussed below.

The four oxygenated tars (Georgia Tech, SERI, Rome, Georgia, Rocky Creek) exhibit a great deal of similarity in chemical composition. The two entrained tars appear to be nearly identical when analyzed by IR or proton NMR. The IR spectra show strong carbonyl, hydroxyl, and ether bands and the NMR gives evidence of methyl-aryl ethers and aromatic aldehydes. The GC/MS suggests that the single major difference between the two tars is that the SERI tar, produced from softwood, contains almost no dimethoxyphenolic material whereas the Georgia Tech tar, produced from hardwood, contains noticeably more dimethoxyphenolics than the singlely substituted type. This difference is suggestive of the difference between the lignin structure of the softwoods and the hardwoods. Both tars contain small amounts of the lower molecular weight PAH. The actual split of aromatic versus aliphatic carbon structures is hard to determine for these samples due to the poor quality NMR and Targe hydroxyl bands in the IR.

On the other hand, significant differences can be noted between the gasifier tars and the entrained pyrolysis tars. Of the gasification tars, the updraft tar from Rome, Georgia, appears to be less severely treated based on 


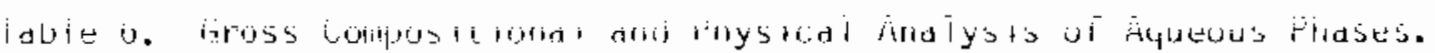

\begin{tabular}{|c|c|c|c|c|c|c|c|c|c|c|}
\hline & $\begin{array}{l}\text { Rome } \\
\text { Georgia }\end{array}$ & $\begin{array}{l}\text { Rocky } \\
\text { Creek }\end{array}$ & $\begin{array}{l}\text { Univ. } \\
\text { Florida }\end{array}$ & $\frac{\mathrm{Cal} \text { Recovery }}{\text { Halnuts }}$ & $\frac{\text { Systems }}{\text { RDF }}$ & $\begin{array}{l}\text { SERI } \\
\text { Downdraft }\end{array}$ & $\begin{array}{l}\text { Univ. } \\
\text { Missouri }\end{array}$ & $\begin{array}{l}\text { PNL } \\
\text { Fluid }\end{array}$ & $\begin{array}{l}\text { IGT } \\
\text { Fluid }\end{array}$ & $\begin{array}{l}\mathrm{BCL} \\
\text { Pine }\end{array}$ \\
\hline Carbon, \% & 11.3 & 7.0 & 3.3 & 0.8 & 0.3 & 0.5 & 0.2 & $<0.1$ & $<0.1$ & $<0.1$ \\
\hline TOC, ppm & 170,100 & 70.980 & 29,860 & 11,220 & -- & 4990 & -- & 110 & 387 & - \\
\hline Sulfur, ppri & 12 & 26 & 38 & 3.7 & 32 & -- & -- & 1.8 & 1.5 & 31 \\
\hline Ash, \% & 0.1 & 1.4 & 1.7 & 0.04 & 0.03 & 0.02 & -- & 0.1 & 0.06 & 0.06 \\
\hline $\begin{array}{l}\text { Trace } \\
\text { Element, } \\
\text { ppm }\end{array}$ & $\begin{array}{c}472 \mathrm{~K} \\
55 \mathrm{Fe} \\
44 \mathrm{Ca} \\
14 \mathrm{Zn}\end{array}$ & $\begin{array}{c}9300 \mathrm{Fe} \\
304 \mathrm{Ca} \\
35 \mathrm{~K} \\
33 \mathrm{Zn} \\
208 \mathrm{Al} \\
29 \mathrm{Mn}\end{array}$ & $\begin{array}{c}9820 \mathrm{Fe} \\
75 / 4 \mathrm{n} \\
70 \mathrm{~K} \\
43 \mathrm{Ca} \\
16 \mathrm{Zn} \\
15 \mathrm{C} 1\end{array}$ & $\begin{array}{r}28 \mathrm{Zn} \\
13 \mathrm{Si} \\
12 \mathrm{Fe} \\
9 \mathrm{Ca} \\
8 \mathrm{Cl}\end{array}$ & $\begin{array}{c}44 \mathrm{Cl} \\
22 \mathrm{Fe} \\
22 \mathrm{Zn} \\
9 \mathrm{Ca} \\
6 \mathrm{~K}\end{array}$ & -- & -- & $13 \mathrm{Cl}$ & $45 \mathrm{Si}$ & $\begin{array}{c}15 \mathrm{Cl} \\
7 \mathrm{Ca} \\
3 \mathrm{Fe} \\
2 \mathrm{~K}\end{array}$ \\
\hline $\mathrm{pH}$ & 2.1 & 4.0 & 4.8 & 3.1 & 3.0 & 5.3 & 5.9 & 8.7 & 7.6 & 6.0 \\
\hline $\begin{array}{l}\text { Density, } \mathrm{g} / \mathrm{m} 7 \\
\text { @2 } 4^{\circ} \mathrm{C}\end{array}$ & 1.059 & 1.04 & 1.031 & 1.000 & 0.995 & 0.99 & -- & 0.998 & $\cdots$ & 0.990 \\
\hline $\begin{array}{l}\text { Viscosity, } \\
\text { (a) } 31^{\circ} \mathrm{C}\end{array}$ & 1.8 & 1.6 & 1.4 & 1.3 & 1.1 & 1.2 & 1.2 & 1.1 & -- & 1.1 \\
\hline
\end{tabular}


examination of the GC/MS results. For example furan containing components have survived as have the levoglucosan and abietic acids. The low-molecular weight, polar organics are undoubtedly present in larger quantities then indicated by the data tabies; however the specific chromatography used in this particular analysis tends to lose these components in the background. Additional alternate chromatography techniques need to be applied for analysis of these components such as was done in our study of liquefaction products (29). The PAH appear in only minor amounts with no indication of higher molecular weight PAH. The relatively larger amounts of monomethoxyphenols indicates that pine made up a substantial portion of the feedstock which produced this tar. The Rocky Creek downdraft tar, on the other hand, contains none of the early cellulose pyrolysis products but is primarily phenolic (dimethoxyphenolic, suggesting the hardwood feedstock). There is a significant portion of PAH in the Rocky Creek tar which indicates a more severe processing environment.

The other end of the spectrum of tar composition is represented by the $\mathrm{BCL}$ tars. The IR, NMR and GC/MS all show that the BCL tars are primarily aromatic with very little substitution of any kind. The similar IR spectrum from the oil skim on the IGT condensate suggests that the high temperature, fluidized bed units will all produce a similar tar product. The GC/MS anaiysis of the $\mathrm{BCL}$ tars identified nothing but PAH and the NMR indicates that the tars are nearly pure aromatic. These same analyses show only slightly reduced levels of aromatization in the SERI cracked tar. The SERI cracked tar was determined to be about $82 \%$ aromatic by Carbon-13 NMR including some phenolic material. Phenol was identified in the SERI cracked tar by GC/MS as well as PAH compounds.

Aqueous Phase Analysis

The IR and NMR techniques are not particularly useful with dilute aqueous solutions. The GC/MS technique including methylenechloride extraction prior to sample injection to the GC can also leave significant portions of the aqueous phases unanalyzed since the extraction technique is of limited use to recover the highly polar components. The GC/MS analyses performed here provide much information about the organic components dissolved in the byproduct water streams; but the highly polar. low molecular weight components would not be seen by this technique due to the poor resolution of these components with the chosen chromatography analysis. As a result, these analyses may provide a depiction of the dissolved organics which is biased toward the Jower polarity components. Since the polar. low molecular weight components such as acetic acid or methanol are likely to be major components in some of the aqueous streams, additional analyses should be done in order to quantify the organic contaminants in the aqueous phases.

As with the tars, the aqueous phase organic components cover a broad range of chemical functionalities. The updraft and downdraft condensates still exhibit a great deal of biomass-derived chemical structure including the furans and methoxyphenols. Much of this character is missing in the SERI downdraft condensate while the first nitrogen containing components are identified. The fluidized-bed gasifier condensates contain only traces of low molecular weight furan structure and none of the methoxy phenols. Instead the oxygen is found as methylated phenols or higher molecular weight structures, such as cyclic ethers. The nitrogen-containing heterocyclics are generally 
present. A large portion of the organic is found as benzenes and PAH compounds. In considering Table D-4 (in Appendix D) the general trend of decreasing phenolics and increasing PAH across the table of the four fluidized-bed units is obvious. The four samples are presented in order of increasing gasifier operating temperature.

\section{BIOLOGICAL ACTIVITY MEASUREMENTS}

All of the samples included in this analytical program have been subjected to the Ames assay to determine a preliminary estimate of the potential mutagenic activity of these materials. Tables of numerical results can be found in Appendix E. Higher concentration studies $(100-2500 \mu \mathrm{g} / \mathrm{plate})$ were performed on the aqueous phases in order to increase the effect of the dilute organic materials. No activity was found in any of the aqueous phases, even those from the fluidized-bed gasifiers which contained PAH. Of all the samples only the BCL tars (both pine and hardwood) exhibited with certainty activity above background leveis. The IGT condensate also exhibited very weak activity that is inconclusive. These determinations with tars were made at concentrations of 2-500 $\mathrm{ug}$ per plate. One tar, the SERI cracked tar, was tested over a concentration range from 100-2500 g per plate. Although at the low end of the concentration range no activity was evident, at the higher concentrations (1000-2500 $\mathrm{\mu g} / \mathrm{plate}) \mathrm{killing}$ of the cultures by the test material interfered with the measurement of the cultures by the analytical instrumentation and made hand-counting of the cultures necessary. Although the instrumental results suggested activity for this sample, hand counting of the cultures indicated only background activity was present. 


\section{DISCUSSION OF RESULTS}

These analytical results conclusively show that a 11 biomass gasification/pyrolysis tars are not the same. There is no typical tar composition that can be adequately used. The tar composition (as well as amount, which has already been adequately demonstrated by others) is dependent on the operating conditions, principally a time/temperature thermal severitytype function. The properties of the tar therefore appear to vary on a continuum including the "primary" oxygenated pyrolysis tar collected after a short residence time at low temperatures of around $500^{\circ} \mathrm{C}$ and the highly aromatic, deoxygenated tar which is produced at short residence time at high temperatures of around $900^{\circ} \mathrm{C}$. This continuum of tar cracking/condensation appears to argue against any purely pyrolytic mechanisms for complete conversion of biomass to tar-free gas without char The intermediate products of suct a progression would be some grade of tar and char with the end product being a finite amount of graphite.

That the tar formed by thermal decomposition of biomass is not thermally stable and tends to further degrade to gas and char is well-known. However, changes in the tar composition by further treatment is not as widely recognized. An eariy suggestion of the transformation of "primary tar" to "secondary tar" is made by Haegglund (49) who also states that the composition of the tar is temperature dependent although no data is given. Transformation of coal tar as a function of temperature is well-known and similar chemistry appears to occur in the case of wood tar also.

\section{THE EFFECT OF PROCESSING CONDITIONS}

It is now apparent based on the analyses reported here that a spectrum of tar condensates can be recoverd from entrained-flow or fluidized-bed reactors processing wood over a temperature range from $450^{\circ}-950^{\circ} \mathrm{C}$. In these shortresidence time reactors the extent of progression along a path of thermal decomposition is dependent on the upper temperature achieved in the reactor. Unfortunately, the work reported to date has been performed on ly in the temperature ranges from $450^{\circ}$ to $550^{\circ} \mathrm{C}$ and $750^{\circ}$ to $900^{\circ} \mathrm{C}$. Therefore, a significant portion of the intermediate range products have not been recovered and analyzed. However, the transformation of the SERI entrained-flow primary tar into the SERI cracked tar clearly demonstrates the thesis. The primary oxygenated tar produced from wood pyrolysis at $450^{\circ} \mathrm{C}$ can be changed into the highty aromatic, deoxygenated tar by additional thermal treatment at $750^{\circ} \mathrm{C}$. These reactions are very fast and require only short residence times on the order of fractions of seconds. Whether there is a smooth continuum or a sharp demarcation between the oxygenated and deoxygenated products at some intermediate temperature around $650^{\circ} \mathrm{C}$ is, as yet, unknown, and further study is required.

The placement of the organic condensates from fixed bed gasifiers within this tar property continuum is more subject to specific process

configurations. The range of properties of the condensates from the downdraft gasifiers within this program adequately demonstrates this difficulty. In theory the organic vapors from the properly designed downdraft gasifier should be completely combusted in the combustion zone at the bottom of the reactor before they can escape with the gaseous product. Practically speaking, such complete combustion is not obtained and the extent of organic contamination in 
the downdraft condensate is mainly a measurement of the efficiency of the combustion zone. The potential for channeling in the bed such that pyrolysis vapors bypass the combustion zone is a primary concern of the gasifier designer/operator. The efficiently operating downdraft gasifiers apparently do not allow enough organic vapor bypass that a separate organic phase is produced in the condensate. The types of organic components which do escape the gasifier can vary over the entire range of tar chemical composition.

The analysis of these organic components which escape a downdraft gasifier may provide significant information in diagnosing the reason for tar carryover into the product gas. With a proper understanding of the tar formation reactions as a function of time and temperature a judgement can be made as to the environment to which the tar components have been exposed. For example, a partial bypass of the high-temperature zone by channeling should produce a mix of low-temperature, oxygenated tar and high-temperature cracked tar while a low bed temperature due to too low air/fuel ratios should produce only low temperature tar. Tar analysis as a diagnostic tool for gasifier operation needs further investigation to determine its validity.

Equally of concern with some downdraft gasifiers is the collection of an organic containing condensate from the top of the bed. This procedure, which is found on the Florida gasifiers of Swedish design, serves to maintain product gas quality but also produces a byproduct stream which must be considered. Analysis of the condensate may also serve as a diagnostic tool for gasifier operation. Handing and disposal of the condensate will be dependent on composition which can vary significantly based on the two samples included in this project.

In the case of updraft operation we have only one sample to consider. It appears to be very similar to the well-known pyrolys is condensate which is recovered from batch carbonization of wood. The condensate is two phase with a heavy organic phase containing the typical components found in "settled tar" from charcoal manufacture. The lighter aqueous phase is highly acidic and carries a large amount (20 to 25 percent by weight) of dissolved organic material much like "pyroligneous acid." The facts that the two phases separate and that the tar contains less oxygen and less dissolved water and is less dense indicate that the updraft tar is slightly more thermally processed than the primary tars from the entrained-flow pyrolyzers.

The updraft tar appears to be a lower molecular weight product than the entrained-flow tars based on at least three observations. First, it is more volatile in that a larger percentage can be vacuum distilled (over $50 \%$ of the organic portion compared to less than $1 / 3$ for the entrained tars). The distillation curve indicates that the more volatile nature may be more accurately attributed to the greater thermal stability of the tar. The updraft tar also gave a much better performance in the chromatography analyses, although only $20 \%$ could actually pass through in the chromatograph. Finally, the MMR analyses were greatly facilitated by the good solubility and solution properties of the updraft tar in deuterated chloroform.

The NMR spectra provide quantitative data about the makeup of the tar that suggests that $2 / 3$ of the carbon is found in aromatic structures while $1 / 3$ is aliphatic (including 2 percent carbonyl and 3 percent methoxyl groups on 
aromatic systems). However, 80 percent of the hydrogen is associated with the nonaromatic structures in the tar components. There was no difficulty with the limited solubility attributed to high molecular weight which stymied the NMR attempts with the entrained flow tars.

\section{CHEMICAL COMPOSITIONAL CHANGES}

A general process of deoxygenation and dehydrogenation can be seen by the comparison of the elemental analysis of the tars recovered from processes of increasing thermal severity (see Table 4 ). This process is reflected in identification of volatile components recovered from the various processes. For example, the low-temperature, entrained-flow pyrolyzates contain significant amounts of highly oxygenated compounds including a plethora of alkylated phenolic ethers. This material is nonexistant in the hightemperature entrained-flow tars which contain a collection of PAH with almost no substituted alkyl groups. Further evidence for this process can be found in comparing the aqueous phase organics recovered from the four fluidized bed units. The concurrent decrease in phenols and increase in PAH as a function of temperature is demonstrated in. Figure 12. This same effect is well-known for coal tars (10). A graph from Lowry (10), shown as Figure 13, clearly shows the same effect of decreasing phenol and increasing naphthalene concentration in coal tar as the temperature of the coke oven is increased.

A general pathway of tar chemical functional degradation is suggested below. This hypothetical pathway is meant to represent the nature of the tar composition as a function of thermal processing with the full realization that specific mechanisms can bypass steps in the pathway or alternatively

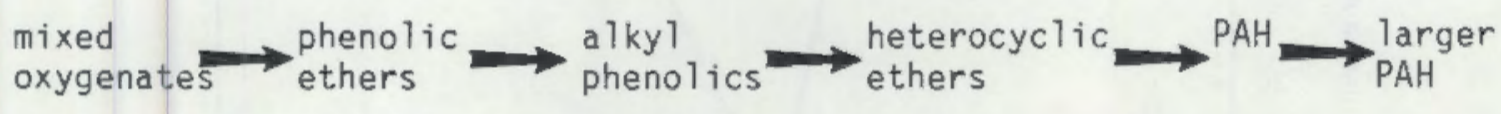

result in gas or char formation. The initial steps of breakdown of high molecular weight biomass polymers into low molecular weight oxygenates is outside the scope of this study.

The analysis and quantitation of low molecular weight oxygenates, like acetic acid, methanol, etc., has received limited effort in this study. The presence of substantial amounts of these compounds in the entrained-flow pyrolysis tars has been reported (50). The use of alternate GC conditions would allow the analysis of these materials, however, the use of solvents to facilitate injection of the tars into the $\mathrm{GC}$ also interferes with the analysis by obliterating a portion of the chromatograph. The light oxygenates should be present in decreasing amounts as the thermal severity of the process increases as evidenced by elemental analysis of the tar composition.

\section{CONDENSATE PROCESSING AS GASIFICATION BYPRODUCTS}

Although we have analyzed all of these condensates due to their potentia? as byproducts, in fact, many of the processes handle the condensate by consuming it in some manner. For example, the condensate (both tar and aqueous) from the updraft gasifier is fired along with the gas in a boiler, and the tar condensate from the BCL gasifier is also projected as fuel for the combustion step. But in many cases, the condensates, primarily the aqueous streams, will require treatment and disposal. Alternately, in the entrained- 


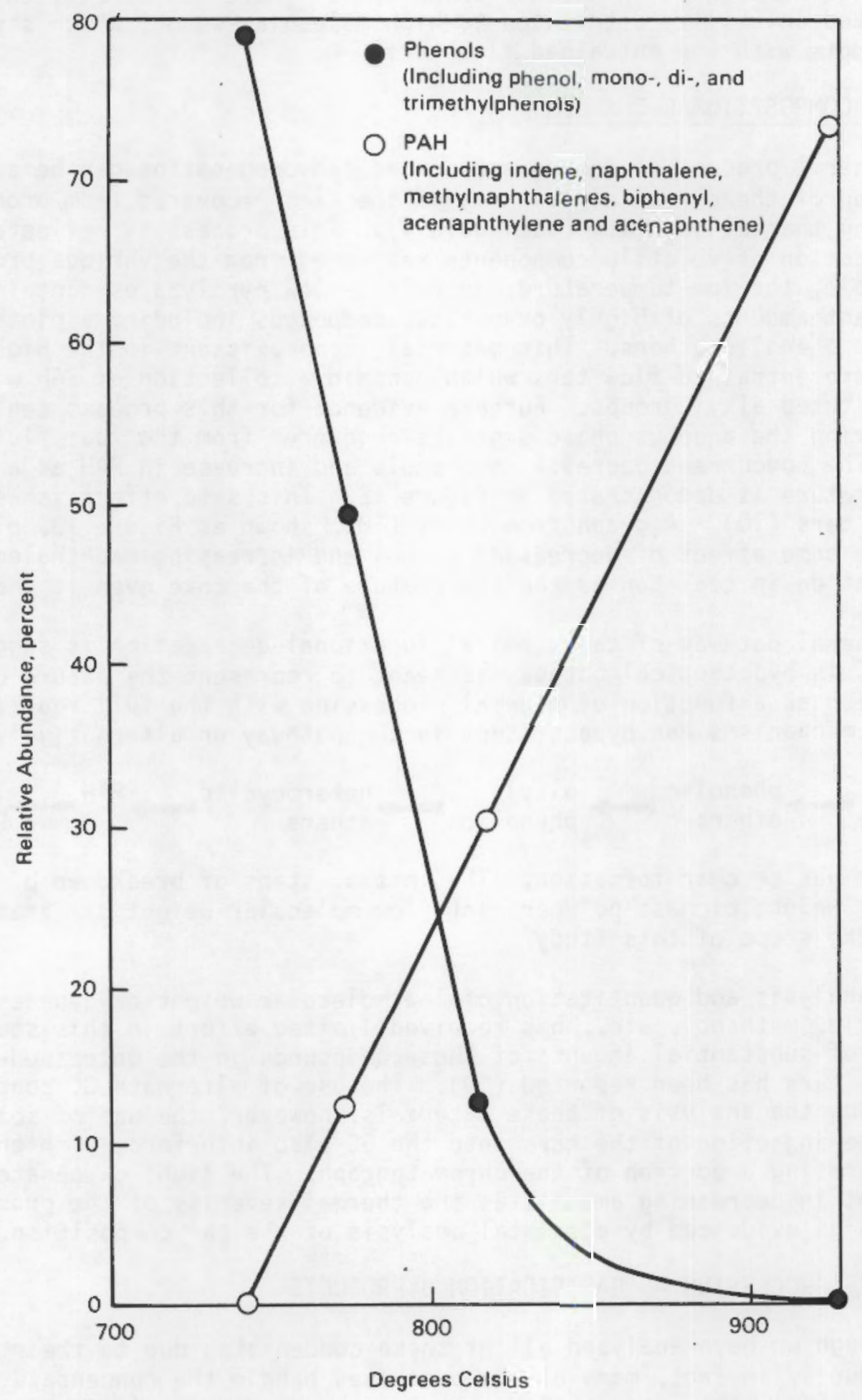

Figure 12. Shift in Chemical Composition of Aqueous Phase from Fluidized Bed Gasifiers. 


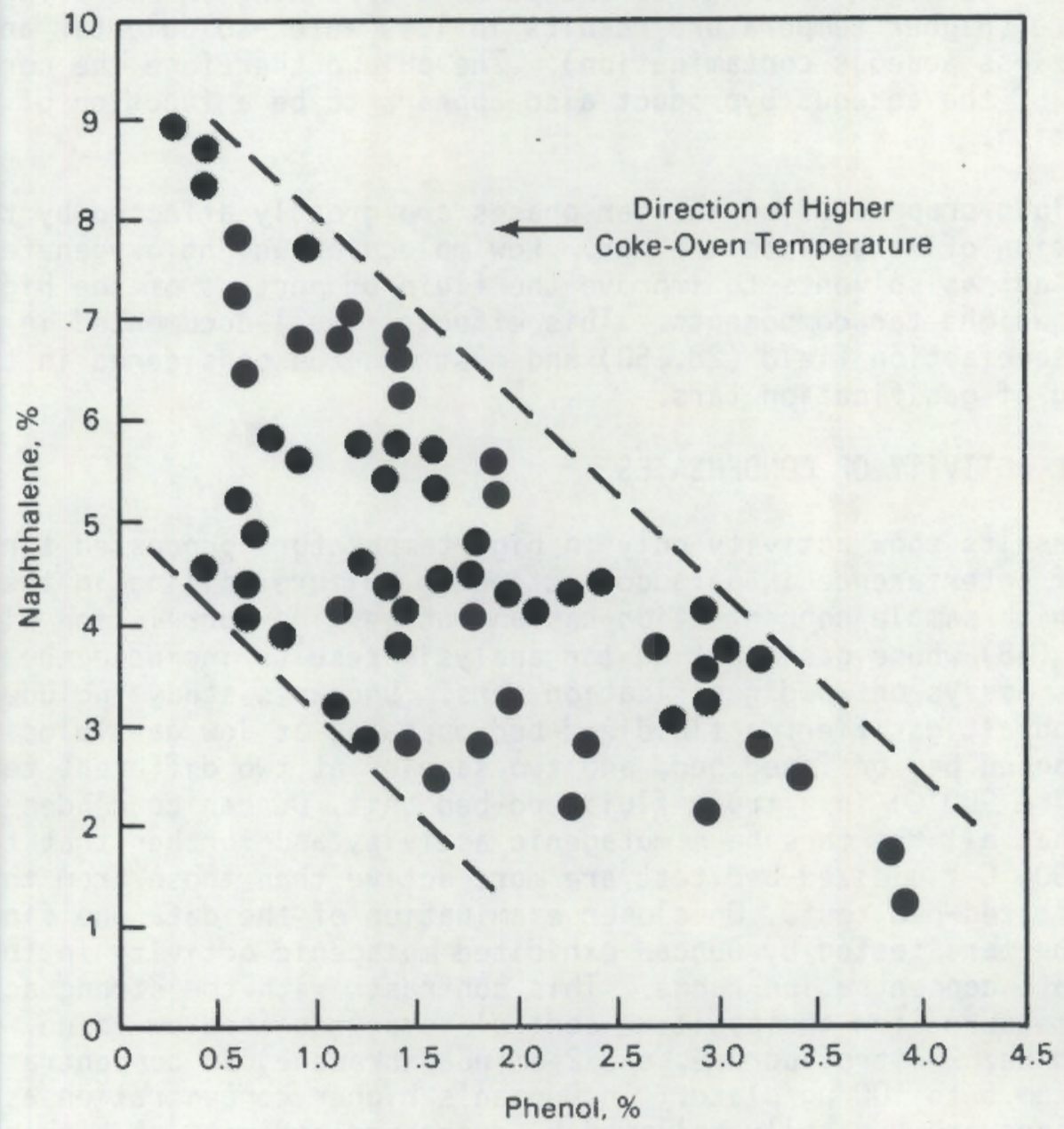

Figure 13. Phenol Content vs. Naphthalene Content of Coke-Oven Tars. 
flow pyrolyzers the tar is the main product and will be used as fuel, either directly or following upgrading of some kind.

The aqueous condensates have a wide range of concentration of organic contaminants. Although the limited amount of previous research included organic carbon concentrations of 1 to 2 percent $(26,27)$ our study shows that some aqueous byproducts will range up to 3 to 7 percent, as in the case of the Florida gasifiers (Rocky Creek and University of Florida). Typical downdraft condensates will be in the range of one percent with the fluidized-bed condensates less than or equal to one percent depending on operating temperature (higher temperature results in less water-soluble tar and therefore less aqueous contamination). The $\mathrm{pH}$ and therefore the corrosive potential of the aqueous byproduct also appears to be a function of organic contamination.

The fluid properties of the tar phases are greatly affected by the incorporation of water into the tar. Low molecular weight oxygenates also appear to act as solvents to improve the fluid properties of the higher molecular weight tar components. This effect is well-documented in the biomass liquefaction field $(28,50)$ and must also be considered in the processing of gasification tars.

\section{BIOLOGICAL ACTIVITY OF CONDENSATES}

Our results show activity only in high-temperature processed tars. Our finding of interference in data collection by culture killing in the Ames assay at high sample concentration has an interesting correlation with those of Duncan (48) whose gasification tar analysis results included the only other known Ames assays on wood gasification tars. Duncan's study included tars from an updraft gasifier, a fluidized-bed operated at low gas velocity, i.e. as an expanded bed or fixed bed, and two samples at two different temperatures $\left(750^{\circ}-800^{\circ} \& 900^{\circ} \mathrm{C}\right)$ in a truly fluidized-bed unit. Duncan concludes from his results that all the tars have mutagenic activity and further that the tars from the $900^{\circ} \mathrm{C}$ fluidized-bed test are more active than those from the $750^{\circ}-$ $800^{\circ} \mathrm{C}$ fluidized-bed test. On closer examination of the data one finds that none of the tars tested by Duncan exhibited mutagenic activity in the 50 to $500 \mu \mathrm{g} / \mathrm{plate}$ concentration range. This contrasts with the strong activity that was measured for the positive control compounds (sodium azide, 9aminoacridine, 2-nitrofluorene, and 2-aminoanthracene) at concentrations ranging from 5 to $100 \mu \mathrm{g} / \mathrm{plate.} \mathrm{In} \mathrm{Duncan's} \mathrm{higher} \mathrm{concentration} \mathrm{assays} \mathrm{the}$ active assays are typically followed by decreased activity at higher concentration or a complete killing of the culture in many cases (indicated by zero activity). The interference in colony counting by the killing of the cultures at higher sample concentrations is not discussed by Duncan and based on our results we conclude that the activity he reports is actually a result of partial killing of the cultures. Whether the killing of the cultures masks actual mutagenic activity can not be determined at this time.

Mutagenic activity in gasification/pyrolys is condensates varies greatly depending on the processing conditions. It is apparent that the activity correlates strongly with the concentration of high molecular weight PAH in the sample. This result is not surprising. Duncan (48) refers to a Japanese paper in which the carcinogenicity of skin creams derived from biomass tars could be correlated with the content of PAH. Other studies at PNL $(51,52)$ 
with fractionated coal liquids have demonstrated that the mutagenic activity is concentrated in the organic base fraction (nitrogen-containing PAH) and the higher boiling, neutral PAH. The hydroxy-PAH fraction exhibited nearly no activity. similar to the aliphatic fraction. Mutagenic activity has also been correlazed with the amount of aromatic material in a hydrocarbon mixture;

again siggesting that the higher molecular weight PAH are more active mutagens (53).

Based on the above information, a potential processing dilemma has now been identified. Higher temperatures are generally perceived to improve the efficiency and rate of gasification. In addition, our data also suggests that less contamination will remain in the aqueous byproduct stream when the gasification is performed at higher temperature. On the other hand, the tar components that do remain following higher temperature processing are more highly condensed PAH which result in a higher level of mutagenic activity. The transformation from phenolic to PAH is strongly a function of temperature in the range of $700^{\circ}$ to $950^{\circ} \mathrm{C}$. Therefore consideration of the processing requirements for the aqueous condensate stream versus the organic condensate stream may become critical with operating temperature being the major independent variable. 


\section{SUGGESTIONS FOR FUTURE RESEARCH}

This project has served to initiate research in the area of tar analysis as related to gasification byproducts. This analytical research is intended to prov de a basis of understanding so that process engineering can proceed to minimize problems and maximize advantages. As a result of the wide scope of this project a broad field of data has been collected from which we can develop some understanding of tar-forming reactions within the gasification/ pyrolys:s reactors. However, this project has also clearly pointed in several directions in which additional research is necessary to complete our understanding.

The suggestions for future research fall into four main categories:

- Additional analysis of condensates from operating PRUs,

- Detailed Study of Tar Conversion Chemistry from $450^{\circ}$ to $950^{\circ} \mathrm{C}$,

- Aqueous Byproduct Treatment Studies.

- Tar Byproduct Treatment Studies.

Details are given below.

ADOITIONAL ANALYSIS OF CONDENSATES FROM OPERATING PRUS

In several of the cases the samples received for this project were insufficient for a complete analysis. A larger condensate sample is required from both IGT and the University of Missouri-Rolla in order to adequately identify the organic constituents in the tar phase and document their properties. In both of these cases a tar product is produced but in such small quantities that the quantities of condensate provided did not include adequate amounts of the tar phase for analysis. A representative sample is aTSo refuired for the SERI downdraft system in order to determine condensate properties for optimum operating conditions. Such a sample may be very much like the sample analyzed in this project; however, the operating conditions for the present sample included a broad range of conditions. As such, it is an average condensate for a broad range of operations and not necessarily representative of good operating conditions. These limitations on our earlier analytical program point out the importance of a carefully controlled sampling program in which the reactor operation is well-documented and appropriate sampling techniques are used.

An area of analysis which will require additional attention is the determination of low-molecular weight oxygenates in the tars and in the aqueous byproducts. The presence and quantification of these types of compounds will require the application of alternate chromatography techniques. In the case of the low-temperature oxygenated tars they are likely to represent a significant portion of the tar. There is less likelyhood that they would be present in the high temperature tars but further clarification is needed.

Our work with the Ames Assay and the biomass tars has shown that a major shortcoming exists in that the toxicity of the tars interferes with the measurement of mutagenicity at high concentrations. Further study of this problem is required so that alternate techniques can be identified which 
circumvent the difficulty. Clarification of the concentration effect as it relates to the different tars and strains of bacteria would be useful.

A unique opportunity exists relative to the Georgia Tech entrained-flow pyrolysis unit. This PRU is equipped with a muTti-stage cooldown condenser system. Essentially eight condensate fractions are acquired during the operation of the Georgia Tech PRU. Preliminary examination and analysis has shown that these condensates have widely varying composition. Detailed analys is of these fractions could provide useful information to the Georgia Tech program but might also result in a basic understanding of the principles of condensation of the tar vapors. The anaiysis of the fractions would allow the development of the hierarchy of condensation and may provide useful information on fractionation of useful or deliterious components from the tar product.

The PNL catalytic system appears to have a dramatic effect on the amount of tar recovered from a fluidized-bed gasifier. Additional analysis of the organic components recovered from the PNL PRU with or without the secondary catalyst system would help determine the chemical mechanism involved in the catalytic system. Although a separate tar phase is not recovered in the PNL system, a gas scrubbing system consisting of a slip stream of product gas passed through a methylene chloride bubbier has been demonstrated as a viable means to recover organic vapors from the product gas. Comparison of the organics captured in the scrubbers for tests with and without a secondary catalyst could provide useful information on the catalytic system. This catalytic system would have potential application for cleanup of product gas from any biomass gasification system.

\section{OETAILED STUDY OF TAR CONVERSION CHEMISTRY FROM $450^{\circ}$ TO $950^{\circ} \mathrm{C}$}

During the processing of the results of this project it became apparent that the lack of data for thermal processing in the temperature range from $500^{\circ} \mathrm{C}$ to $740^{\circ} \mathrm{C}$ was a major omission. However, since none of the PRUs typically operate in this temperature region, no such samples are available. The second major recommendation for future research is to fill this gap in our knowledge by performing a controlled series of fluidized-bed or entrained flow tests to pyrolyze biomass at temperatures from $450^{\circ} \mathrm{C}$ to $950^{\circ} \mathrm{C}$. The major goal of these tests $w i l l$ be to recover sufficient quantities of tar representative of each operating temperature so that analytical data can be gathered and compared. This series of tests will clearly delineate the changes in tar composition as thermal degradation proceeds through careful control of the time/temperature reaction function. The results of these experiments could play a major role in the determination of the chemical mechanisms involved.

This program of experimentation could be expanded to include not only inert atmosphere pyrolysis but also steam-blown pyrolysis and air-blown gasification. Comparison of the results from these three systems could be extremely valuable in further elucidation of gasification mechanisms. These mechanisms of tar vapor conversion to gas play a major role in a biomass-fed gasification system. The interplay of catalytic systems with these mechanisms could provide decisive new pathways for gas production from biomass.

A significant part of this analytical program should be the quantitation of the low molecular weight oxygenates. The disappearance of these compounds 
following higher temperature processing requires elucidation. A significant determination would be the relative amount of decomposition to gas versus condensation to higher molecular compounds which these compounds undergo.

\section{AQUEOUS BYPRODUCT TREATMENT STUDIES}

The results of this project have shown that gasifier byproduct aqueous streams can range from 100 to 100,000 ppm total organic carbon. Oniy a limited amount of water treatment studies have been reported on biomass gasification-generated wastewater. Now that a better understanding of the range $o^{*}$ contamination in these streams has been determined, additiona? researc' should be performed to determine the appropriate types of wastewater cleanup for different biomass gasification systems. Based on the findings that there is a broad range of amount and kind of organic contamination, it is apparen: that a single waste treatment process will not be appropriate for all gasification systens.

Earlier researchers $(26,27)$ have concluded that neither coagulationflocculation treatment nor solvent extraction is possible with these aqueous streams and neither aerobic digestion nor activated carbon treatment is practical. Only anaerobic digestion or wet air oxidation were determined to be applicable. Further testing of these techniques should be undertaken in order to adequately determine if the byproduct treatment is feasible. Alternate techniques may also be identified based on our findings, such as the utilization of low grade heat to fractionate the aqueous byproducts by distillation to a low concentration aqueous stream which can be sewered and a concentrated organic stream which can be combusted.

\section{TAR BYPIRODUCT TREATMENT STUDIES}

The collection and treatment of byproduct tars will be necessary for most of the jasification systems. Simple combustion of the tars is probably the most straight forward disposal route. Tar separation will be more or less cumbersime depending on the type of tar produced (as determined by the operating temperature). Certain upgrading techniques could be applied to the tars to produce higher value liquid fuels. The techniques would vary depending on the tar composition. Such upgrading studies are already underway in the case of the low-temperature, entrained-flow tars. Application of such techniques to the higher temperature tars may prove more useful. For example the catalytic hydrotreating for phenolic oils (54) may be better applied to a tar produced at higher temperature than the $450^{\circ}-500^{\circ} \mathrm{C}$ currently used to maximize primary tar formation. Such a tar produced at say $600^{\circ} \mathrm{C}$ should be more phenolic and contain less highly oxygenated components and therefore be more amenable to hydrotreatment. Investigation of such a process in conjunction with ongoing hydrotreating research and the tar conversion chemistry research suggested above appears to be a reasonable way to address the question. This modification of current pyrolysis-1iquefaction processes currently under development in both the U.S.A. and Canada could conceivably lead to a more feasible, cost effective route to hydrocarbon liquid fuels from biomass. 


\section{CONCLUSIONS}

A broad range of analytical techniques has been applied to a representative collection of biomass gasification/pyrolysis condensates. The chemical and physical properties of the condensates were demonstrated to vary widely depending on processing conditions. Specific conclusions are as follows:

1. Variations in the chemical composition of the organic components in the tars are reflected in the physical properties of tars and phase stability in relation to the ever present water;

2. The chemical composition of the tar is a reflection of the reactor environment and major changes between low temperature (around $500^{\circ} \mathrm{C}$ ) and high temperature tar (around $800^{\circ} \mathrm{C}$ ) were noted as were the similarities between coal tar and wood tar reactions;

3. The biological activity (as measured by Ames Assay for mutagenicity) appears to be limited to the tars produced at high temperatures as a result the formation of polycyclic aromatic hydrocarbons in high concentrations; however, further development of the Ames Assay as it applies to biomass tars is required;

4. The development of a series of chemical mechanisms to explain the changes in tar composition as a function of processing conditions should be pursued as well as the potential to use the tar analysis as a diagnostic tool to determine gasifier bed conditions;

5. The effect of gasifier/pyrolyzer atmosphere such as steam, nitrogen, air, oxygen, carbon dioxide or methane, on the tar composition is not clear at this time and requires further study; and

6. Further processing of condensates from biomass gasification/pyrolysis has received only limited attention. wastewater treatment and low and hightemperature tar upgrading both need to be studied further. 


\section{ACKNOWLEDGEMENT}

The author wishes to acknowledge the participation of the following coworkers at PNL who performed much of the analytical work:

T. R. Pah 1 - GC/MS,

D. L. Stewart - Ames Assay,

R. W. Sanders - XRF,

W. F. Riemath - Ultimate Analysis, Pour Point, HHV

K. M. McFadden - TOC,

J. A. Franz - NMR. 


\section{REFERENCES}

1. Proceedings of the 16 th Biomass Thermochemical Conversion Contractors' Weeting August 1984, NTIS \#CONF-8405157. Pacific Northwest Laboratory; Proceedings of the 15th Biomass Thermochemical Conversion Contractors: Meeting June 1983, NTIS \#CONF-830323, Pacific Northwest Laboratory.

2. Austin, George, T. Shreve's Chemical Process Industries, 5th Edition, McGraw-Hi11 Book Co., 1984, p. 603.

3. Soltes, E. J. and T. J. Elder, "Pyrolysis" in Organic Chericals from Biomass, I. S. Goldstein, ed. CRC Press Inc., T981.

4. Kaupp, A. and J. R. Goss, "State of the Art for Small Scale (to $50 \mathrm{~kW}$ ) Gas Producer-Engine Systems" Final report to U.S.D.A. Forest Service. Contract \#53-319R-0-141, March 1981.

5. Egloff, G. and P. Van Arsde11, The Petroleum Engineer (15), \#4, pp. 144, $46,48,50,1944$.

6. Nordstrom, 01\}e, "Redogorelse for Riksnamnduens for Ekonomisk Forsvarsberedskap Forsknings-Och Forsoksverksamhet pa Gengasomradetvid Statans Makinprovningar 1457-1963" in Overstyrelsen for Ekonomisk forsvarsberedskap. Sweden 1962.

7. Brink, D. L., "Gasification" in Organic Chemicals from Biomass, I. S. Goldstein, ed. CRC Press Inc., 1981.

8. Generator Gas - The Swedish Experience from 1939-1945 translated by the Solar Energy Research Institute from Gengas. Swedish Academy of Engineering, 1950, avajlable from NTIS \#SERI/SP-33-140.

9. Goldmarı, B. and N. C. Jones, "The Modern Portable Gas-Producer", J. of the Institute of Fuel, (XII), No. 63, 103-140, 1939.

10. Karr. C., Jr. "Low-Temperature Tar" in Chemistry of Coal Utilization, Sufplementary Volume, H. H. Lowry, ed., John Wiley \&ै Sons, New York, 1963.

11. Heiler, J. F., "High-Temperature Tar" in Chemistry of Coal Utilization, Supplementary Volume, H. H. Lowry, ed. John Wiley \& Sons, New York, 1963.

12. McNeil, D. "High-Temperature Coal Tar" in Chemistry of Coal Utilization, Second Supplementary Volume, M. A. Elliott, ed., John Wiley \& Sons, New York, 1981.

13. Diebold, J., "Workshop Summary" in Proceedings: Specialists' Workshop on Fast Pyrolys is of Biomass, October 19-22, 1980, NTIS \#SERI/CP-622-1096.

14. Diebold, J. P. and J. W. Scahill, "Entrained-Flow, Fast Ablative Pyrolysis of Biomass" Annual Report, 1 October 1983 - 30 November 1984, NTIS \#SERI/PR-234-2665.

15. Scott, D. S. and J. Piskorz, Can. J. Chem. Eng. (1984) 62, 404-412. 
16. Rensfelt, E., G. Blomkvist, C. Ekstrom, S. Engstrom, B.-G. Espenas, L. Liinanki, "Basic Gasification Studies for Development of Biomass MediumBTU Gasification Processes" in Energy from Biomass and Wastes III, D. L. Klass, ed., IGT, Chicago (1978), pp. 465-494.

17. Flanigan, V. J., A. Punyakumleard and 0. C. Sitton, Biotech. and Bioeng., Symp. 14, (1985) pp. 3-14.

18. Nunn, T. R., J. B. Howard, J. P. Longwell and W. A. Peters, "Studies of the Rapid Pyrolysis of Sweet Gum Hardwood" in Fundamentals of

Thermochemical Biomass Conversion, R. P. Overend, T. A. Milne and L. K. Mudge, eds., Elsevier Applied Science Publ., London (1985), pp. 293-314.

19. Epstein, E., H. Kosstrin and J. Alpert, "Potential Energy Production in Rura? Communities from Biomass and Wastes Using a Fluidized-Bed Pyrolysis System" in Energy from Biomass and Wastes III, D. L. Klass, ed., IGT, Chicago (1978), pp. 769-780.

20. Desrosiers, R., "Gasification Engineering" in 12th Biomass Thermochemical Conversion Contractors Meeting. Washington, DC, March 18-19, 1989.

21. Rose, G. R., S. P. Singh, M. Onischak, and S. P. Babu, "The Development of Biomass Hydroconversion to Synthetic Fuels - The Effect of Operating Conditions on Devolatilization Product Yields" in Energy From Biomass and Wastes V. D. L. Klass, ed., IGT, Chicago (1981), pp. 613-622.

22. Beck, S. R., U. Mann, R. A. Bartsch, J. Yu, R.-C. Wang, and R. Ruggieri, "Application of SGFM Technology to Alternate Feeedstocks - Phase III" in 12th Biomass Thermochemical Conversion Contractors Meeting, Washington, DC, March 18-19, 1981.

23. Evans, R. J., T. A. Milne, M. N. Soltys, "Fundamental Pyrolysis Studies" in Proceedings of the 16 th Biomass Thermochemical Conversion Contractors' Heeting (1984), pp. 349-373, NTIS HCONF-8405157.

24. Hodam, R. H. and R. 0. Williams, "Small Scale Gasification of Biomass to Produce a Low BTU Gas" in Energy from Biomass and Wastes III. D. L. Klass, ed., IGT, Chicago (1978), PP. 729-748.

25. Montgomery, R. B., "Case Histories of the Commercialization of Combined Fixed- and Entrained-Bed Bionass Gasifiers for Brick KiTns" in Energy from Biomass and Wastes VIII, D. L. Klass ed., IGT, Chicago (1984), PP. 777787.

26. Wakamiya, W., J. V. Maxham, and S. E. Petty, "Biomass Gasification Wastewater Treatment - Interim Report" prepared for DOE by Pacific Northwest Laboratory, (1979) NTIS HPNL-SA-8165.

27. Petty, S. E., N. E. Bell and C. J. English, Jr., "Treatrnent of Biomass Gasification Wastewaters using Wet Air Oxidation. Solvent Extraction, and Reverse Osmosis" in Proceedings of the 13th Biomass Thermochemical Conversion Contractor's Meeting (1981), PP. 718-747, NTIS NCONF-8110115. 
28. Elliott, D. C., "Analysis and Comparison of Products from Wood Licuefaction" in Fundamentals of Thermochemical Biomass Conversion. R. P. Overend, T. A. Mi Tne, and L. K. Mudge, eds., Elsevier Applied Science Put 1 ishers, London (1985), pp. 1003-1018.

29. Elitiott, D. C., "Analysis and Upgrading of Biomass Liquefaction Products" Firal Report, Volume 4 of IEA Co-Operative Project 0-1, Biomass Licuefaction Test Facility (1983).

30. "Model 240 Elemental Analyzer," The Perkin-Elmer Corporation, Norwalk, CT, 1973, revised 1978 .

31. Sanders, R. W., K. B., 01sen, W. C., Weimer and K. K. Nielson, "MultiElement Analys is of Unweighed $0 i l$ Samples by X-Ray Fluorescence Spectrometry with Two Excitation Sources," Anal. Chem., 55 (1983) 1911.

32. Annual Book of ASTM Standards, 1981. Part 23, American Society for Testing and Materials, Philadelphia, PA, 7981.

33. Brookfield Synchro-Lectric Viscometer Instruction Manual, Brookfield Engineering Laboratories, Inc., Stoughton, MA, 1980.

34. Instructions and Methods for Parr Oxygen Bombs, Manual No. 148, Parr Instrument Company, Moline, IL, 1978.

35. Ames, B. N., J. McCann and E. Yamasaki, "Methods for Detecting Carcinogens anc Mutagens with the Salmonella/mammalianmicrosome Mutagenicity Test," Mutation Res. 31 (1975) 347-364.

36. Schirmer, R. E., T. R. Pahl and D. C. Elliott, "Analysis of a Thermochemically Derived Wood 0i1," FUEL, 63 (1984) 368-372.

37. "Instructions Model 281 and 283 Infrared Spectrophotometers" The PerkinElmer Corporation, Norwalk, CT, Apri 1977.

38. Knight, J. A., C. W. Gorton, and R. J. Kovac, "Entrained Flow Pyrolysis of Biomass" in Proceedings of the 16th Biomass Thermochemical Conversion Contractors heeting (1984), NTIS \#CONF-8405157, pp. 287-297.

39. Diebold, J. P. and J. Scahill, "Progress in the Entrained Flow, Fast Ablative Pyrolysis of Biomass" presented at the 12 th Biomass Thermochemical Conversion Contractors Meeting, Washington, DC, March 1981 , NTIS \#SERI/PR-622-1151.

40. Georgia Forestry Commission "Wood Gasification, A Unique llethod of Extracting Energy from the Forests of Georgia, The Rome, Georgia Demonstration."

41a Reed, T. B., 8. Levie and M. Markson, "The SERI Oxygen Gasifjer Phase II" prepared for U.S. DOE by SERI, (1984) NTIS \# SERI/PR-234-2571.

$41 \mathrm{~b}$ Reed, T. B. and M. Markson, "A Predictive Model for Stratified Downdraft Gasification of Biomass" in Proceedings of the 15th Biomass. Thermochemical Conversion Contractor's Meeting (1983), NTIS fCONF-830323, Pp. 139-180. 
42. Savage, G. M., "Research and Development of Biomass Gasifier/Engine Systems" in Proceedings of the 16th Biomass Thermochemical Conversion Contractors 'Meeting (1984) NTIS \#CONF-8405157, PP. 231-244.

43. Shaw, L. W. and D. M. Post, "Performance Enhancement of Engines FueTed with Producer Gas" in Proceedings of the 16th Biomass Thermochemical Conversion Contractors Meeting (1984) NTIS \#CONF-8405157, pp. 21T-222.

44. Feldman, H. F., M. A. Paisley and H. R. Appelbaum, "Conversion of Forest Residues to a Methane-Rich Gas in a High Throughput Gasifier" in Proceedings of the 16th Biomass Thermochemical Conversion Contractors' Meeting, (1984) NTIS \#CONF 8405157, PP. 13-38.

45. Chang, H., R. C. Niemann, K. E. Wilzbach and M. Paisley, "Environmental Characterization Studies of a High Throughput Hood Gasifier" in Energy from Biomass and Wastes VII. D. L. Klass, ed., (1983) IGT, Chicago, pp. 539-544.

46. Kosowski, G. M., M. Onischak, and S. P. Babu, "Development of Biomass Gasification to Produce Substitute Fuels" in Proceedings of the 16th Biomass Thermochemical Conversion Contractors Meeting (1984) NTIS \#CONF8405757 , pp. 39-60.

47. Flanigan, V. J., A. Punyakumleard, H. H. Sineath, 0. C. Sitton, "20" Fire Tube Gasification System" in Proceedings of the 16th Biomass

Thermochemical Conversion Contractors 'Meeting (1984) NTIS \#CONF-8405757, pp. 83-102.

48. Duncan, D. W., "Characterization of Tar Produced During the Gasification of Wood" Final Report from B. C. Research to Environment Canada for ENFOR Project C-53. Contract \#KL229-9-7046. February 1981.

49. HaeggTund, E, Chemistry of Wood, Acaderic Press Inc., New York, NY, 1951, Pp. 533-4.

50. Beckman, D. and D. C. E11 tott, Can. J. Chem. Eng. (1985) 63, 99-104.

51. Pelroy, R. A. and M. R. Petersen, Mutation Research (1981) 90, 309-320.

52. Mahlum, D. D., ir. E. Frazier, R. A. Pelroy, and R. A. Renne, "Comparison of In Vitro and In Vivo Studies with Coal Liquids from the SRC-II Process" September 1983, NTIS \#PNL-4836.

53. Calkins, W. H., J. F. Deye, R. W. Hartgrove, C. F. King, and D. F. Krahn, Fuel (7983) 62, 857-864.

54. Elliott, D. C. and E. G. Baker, "Upgrading Biomass Liquefaction Products through Hydrodeoxygenation" in Biotech and Bioeng. Symp No. 14 (1984) C. D. Scott, ed., John Wiley \& Sons, New York, PP. 159-174.

55. Shaw, L. N., D. M. Post, J. D. Whitney, S. L. Hedden, and D. B. Churchill, "Energizing an Irrigation Pump Engine with Citrus Wood," submitted to Amer. Soc. Agri. Eng. Proceedings (1985). 
APPENDIX A

DISTILLATION CURVES FOR BIOMASS PYROLYSIS/GASIFICATION TARS 
Still Head Temp.

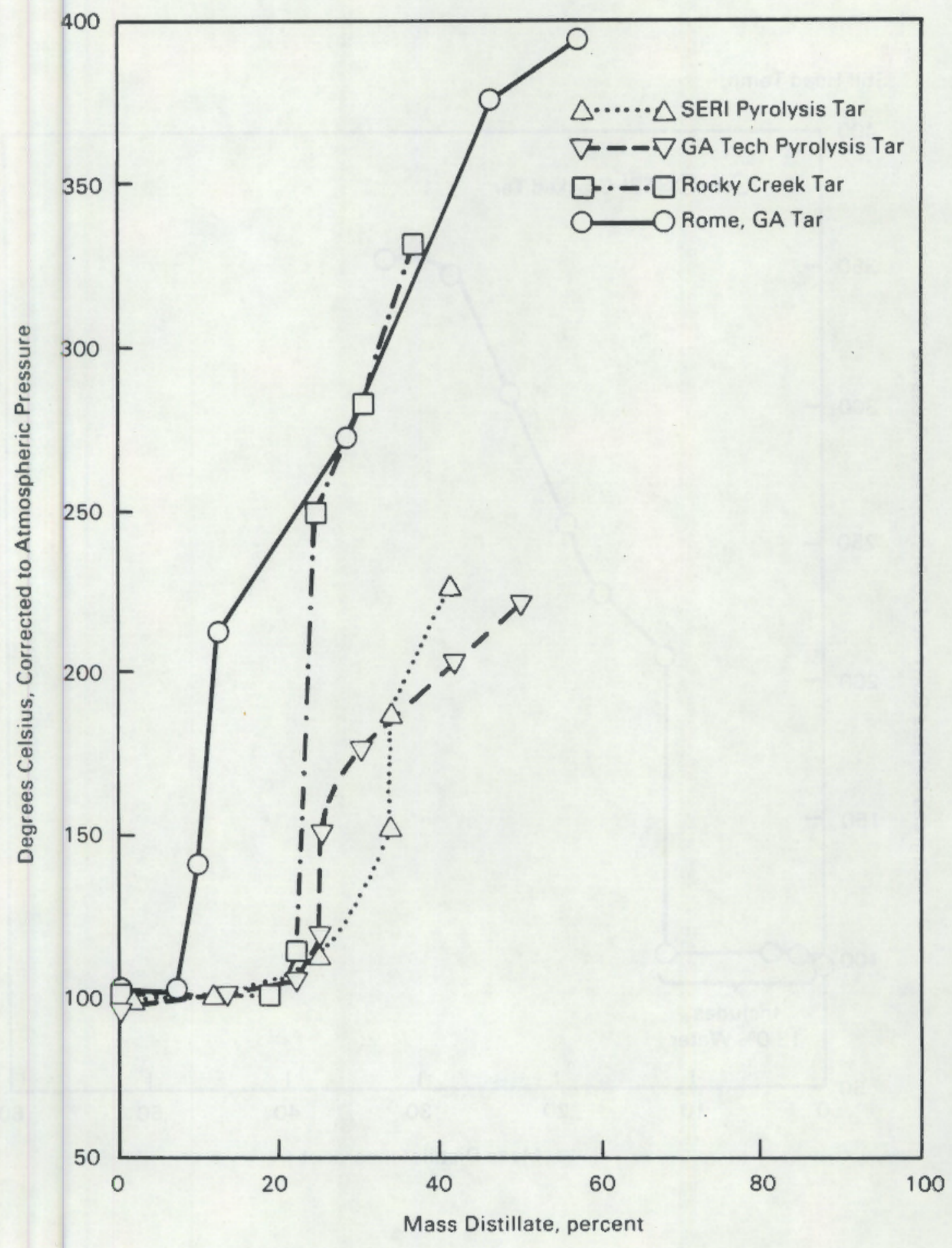

A. 1 
Still Head Temp.

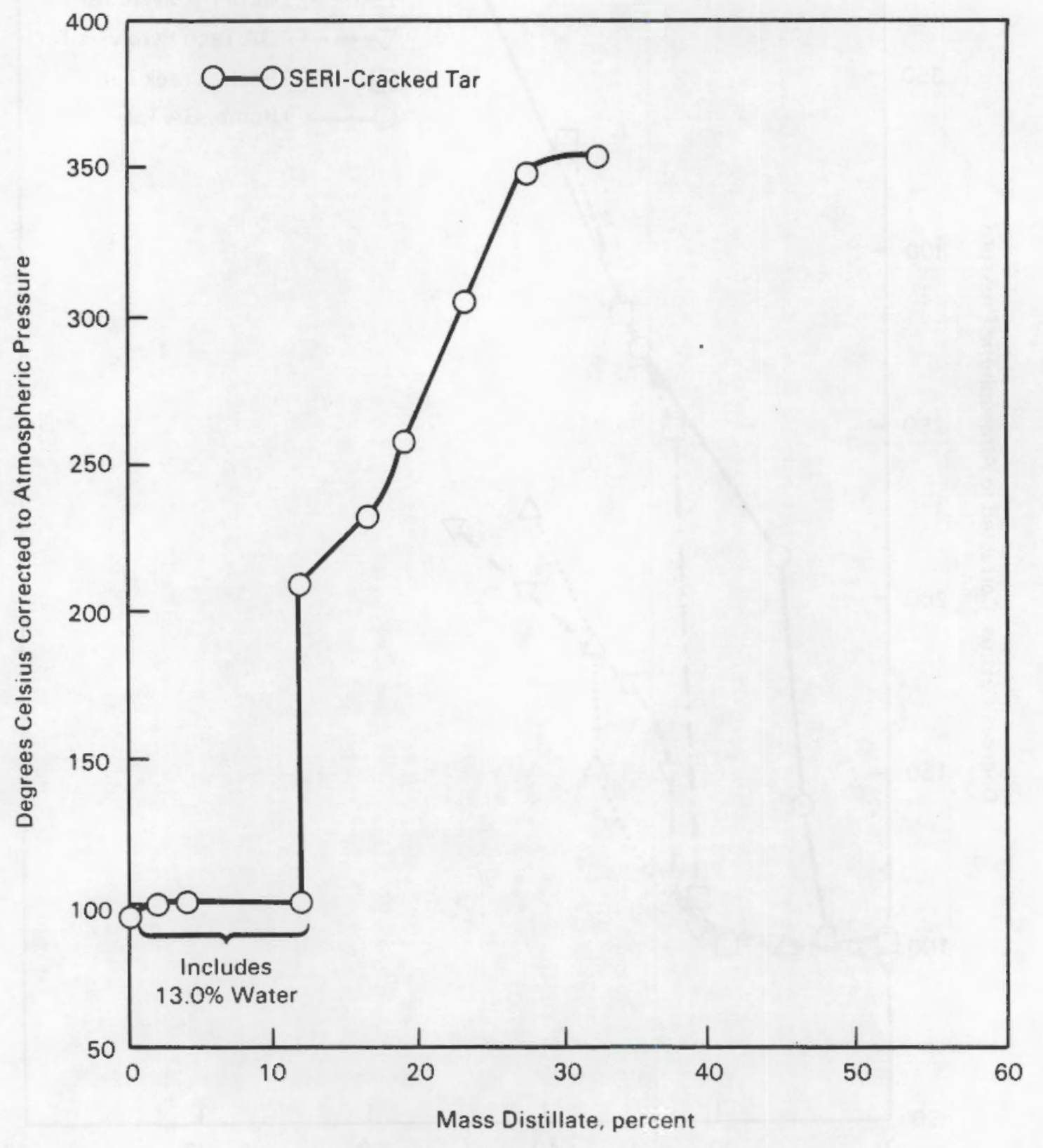

A. 2 
Still Head Temp.

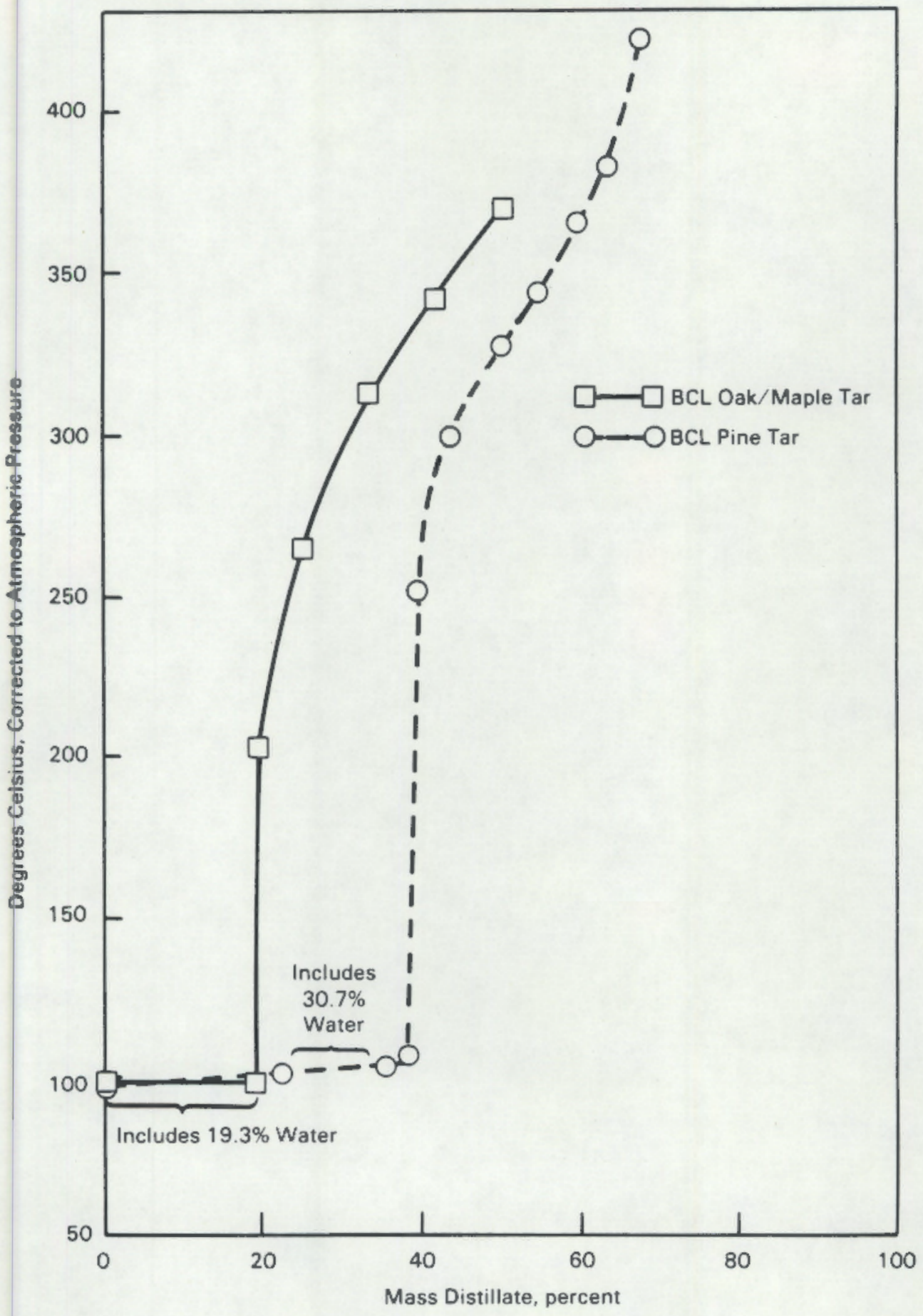

A. 3 

APPENDIX B

INFRARED SPECTRA OF BIOMASS PYROLYSIS/GASIFICATION TARS 

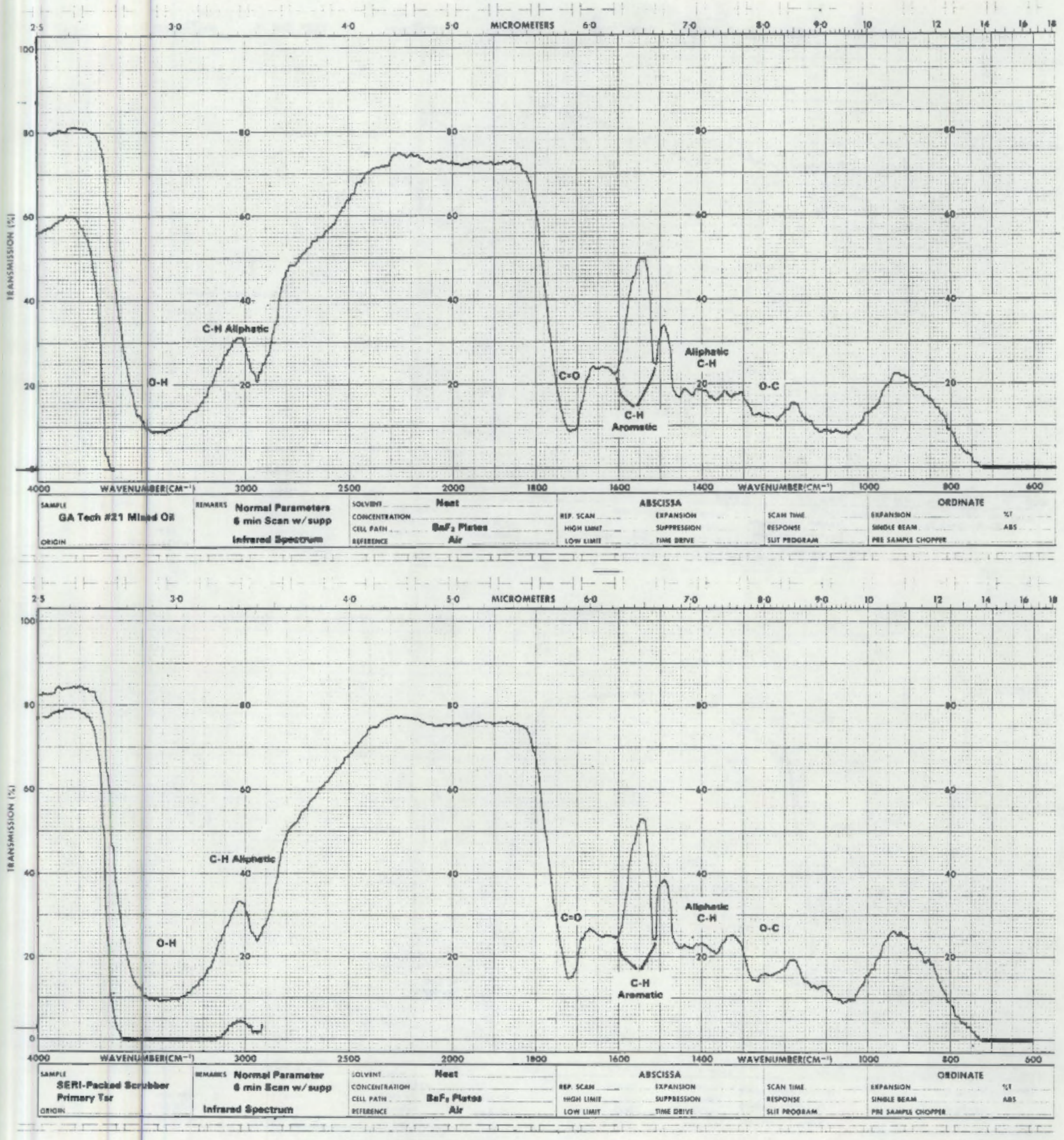

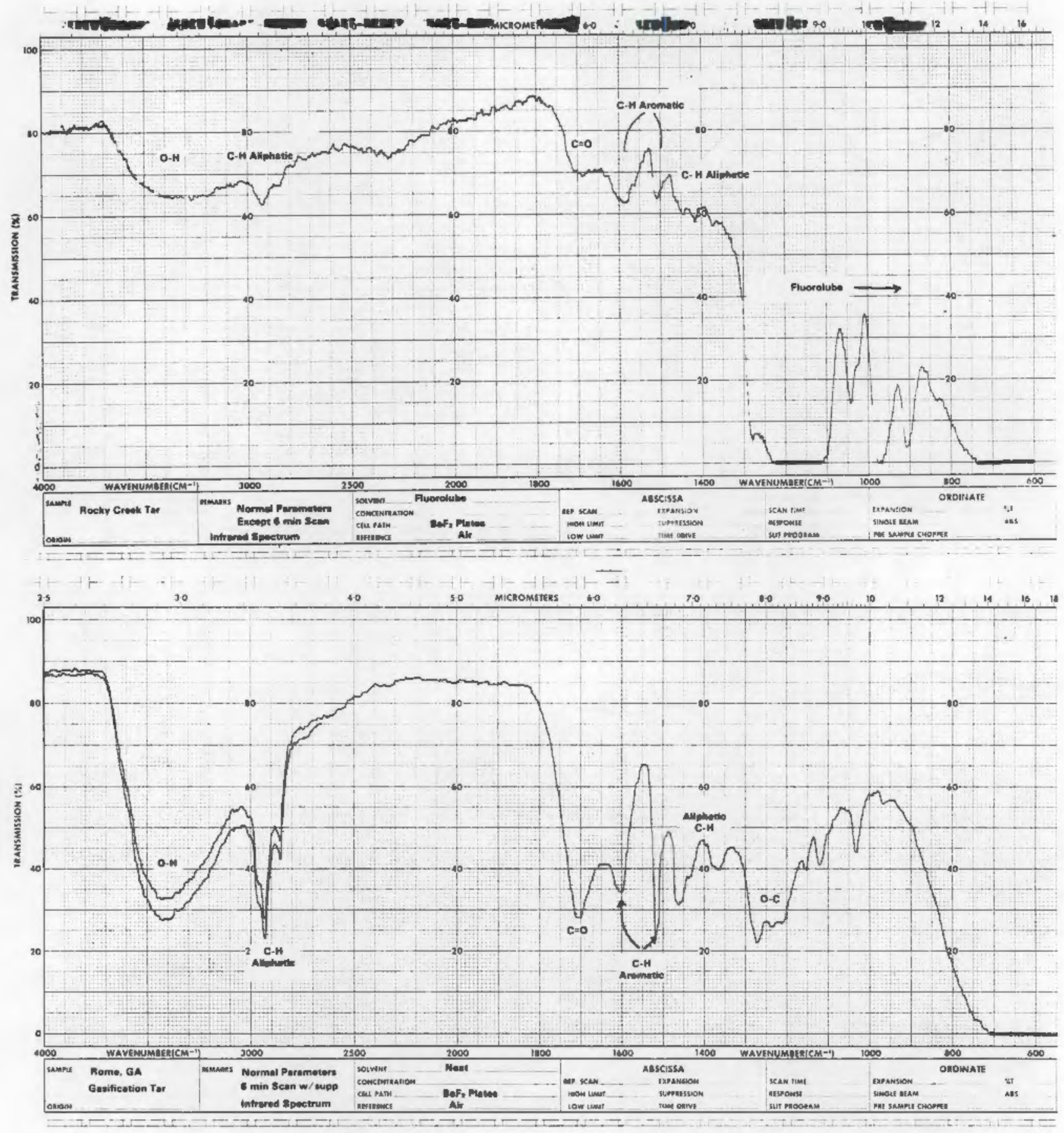

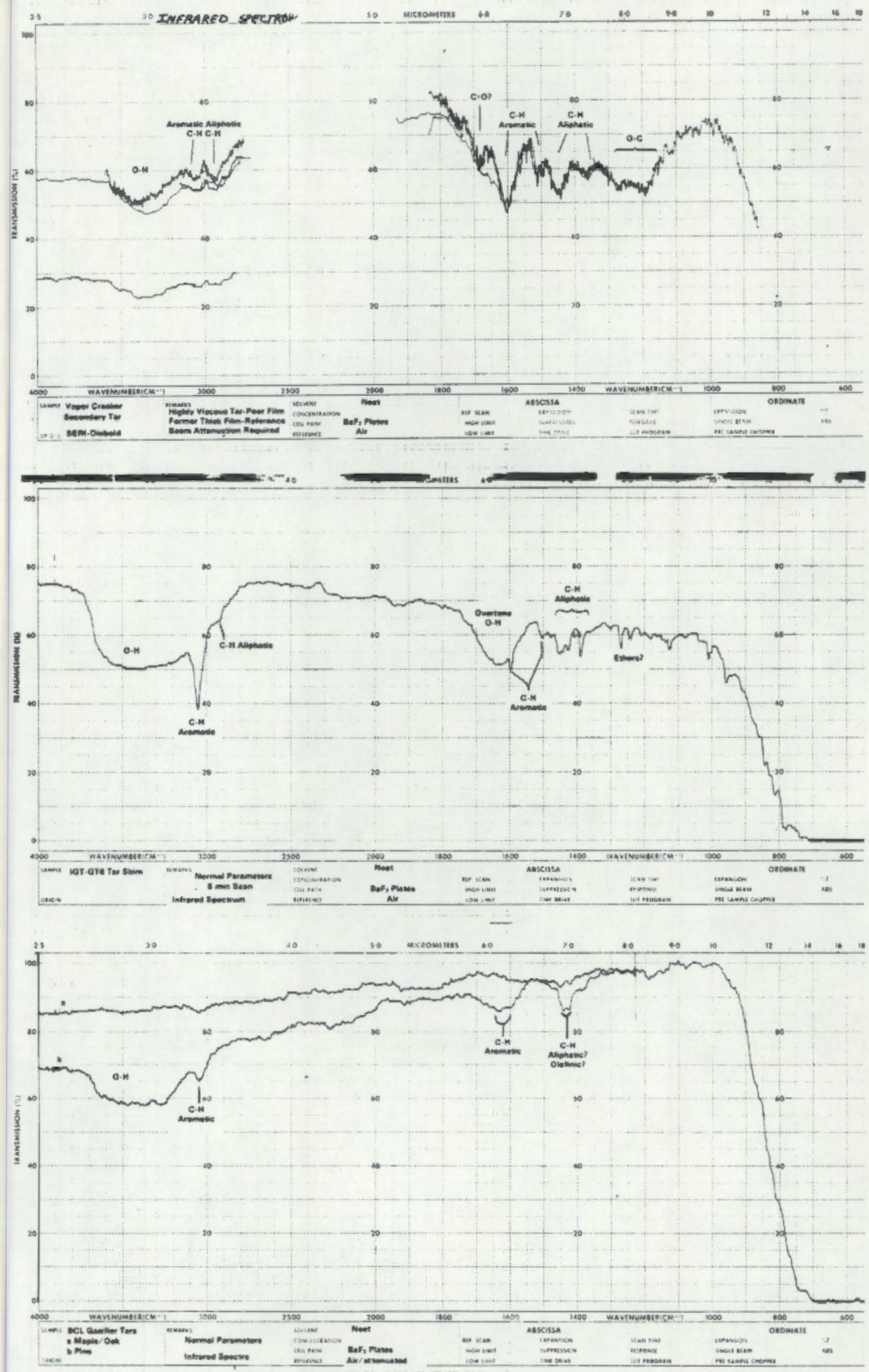



\section{APPENDIX C \\ PROTON AND CARBON-13 NUCLEAR MAGNETIC RESONANCE SPECTRA OF BIOMASS PYROLYSIS/GASIFICATION TARS}




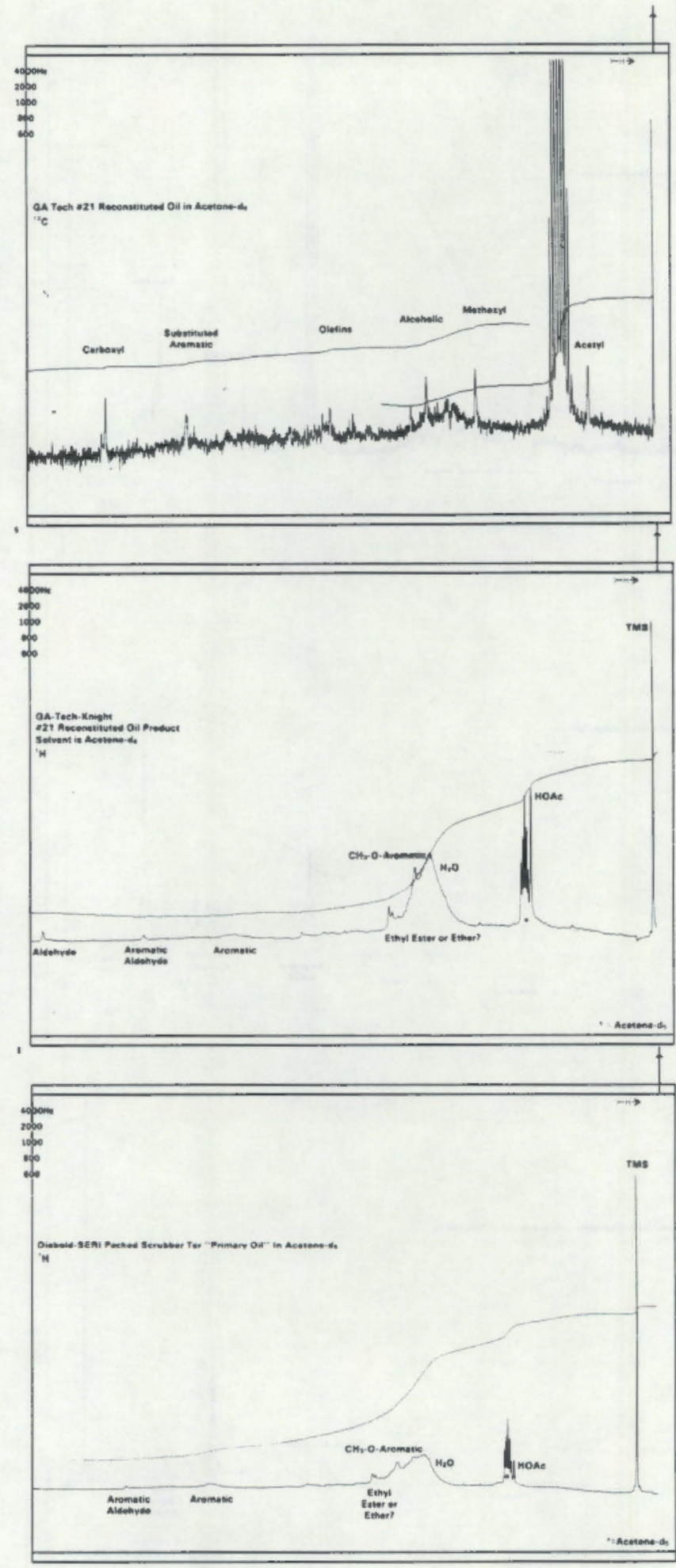

C.1 


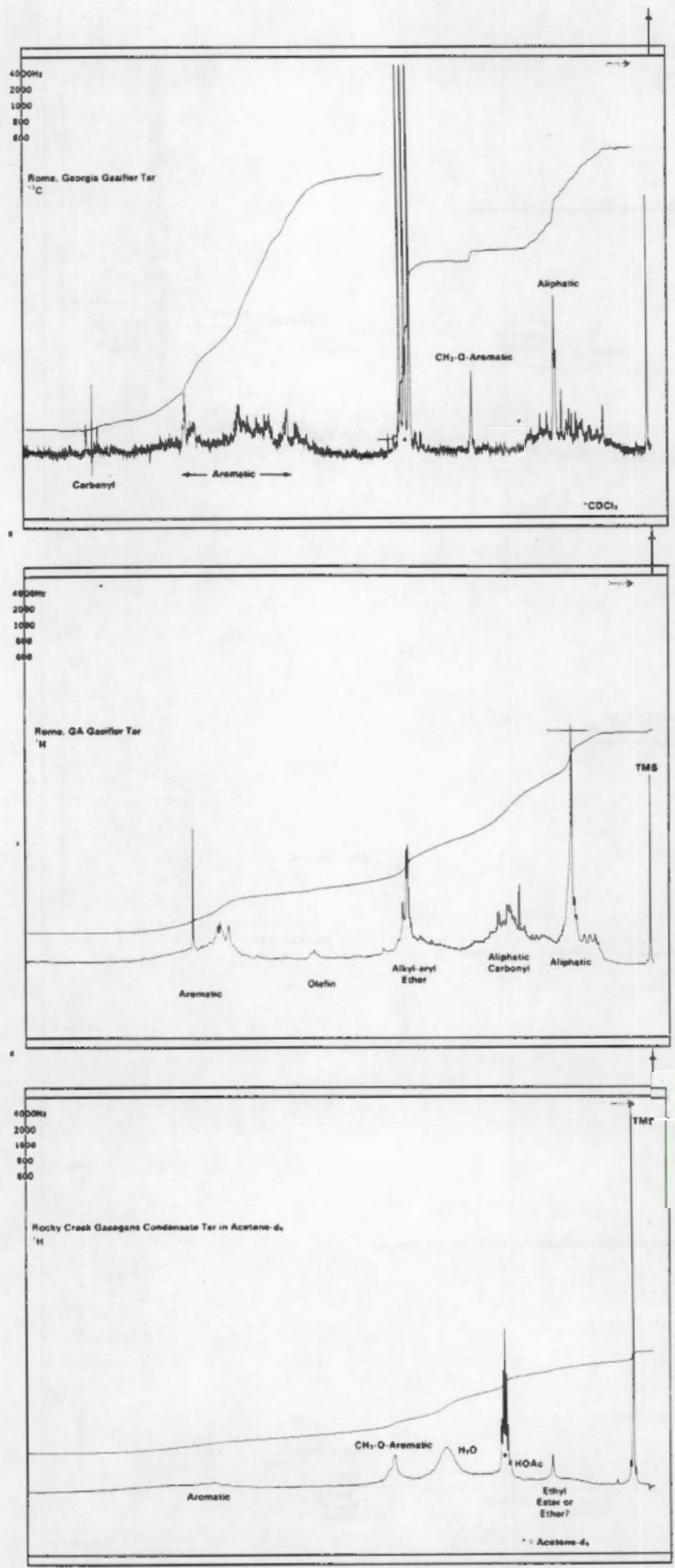

C. 2 


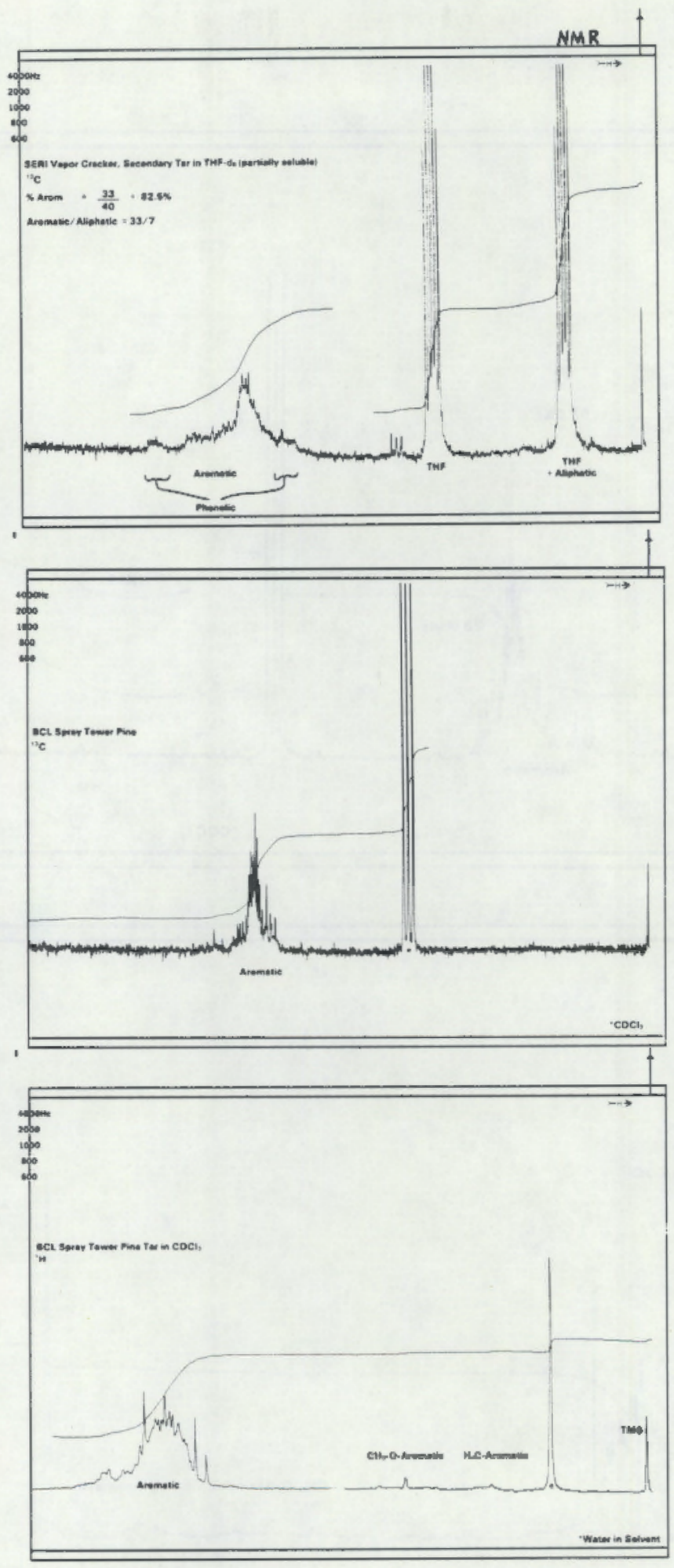

c. 3 


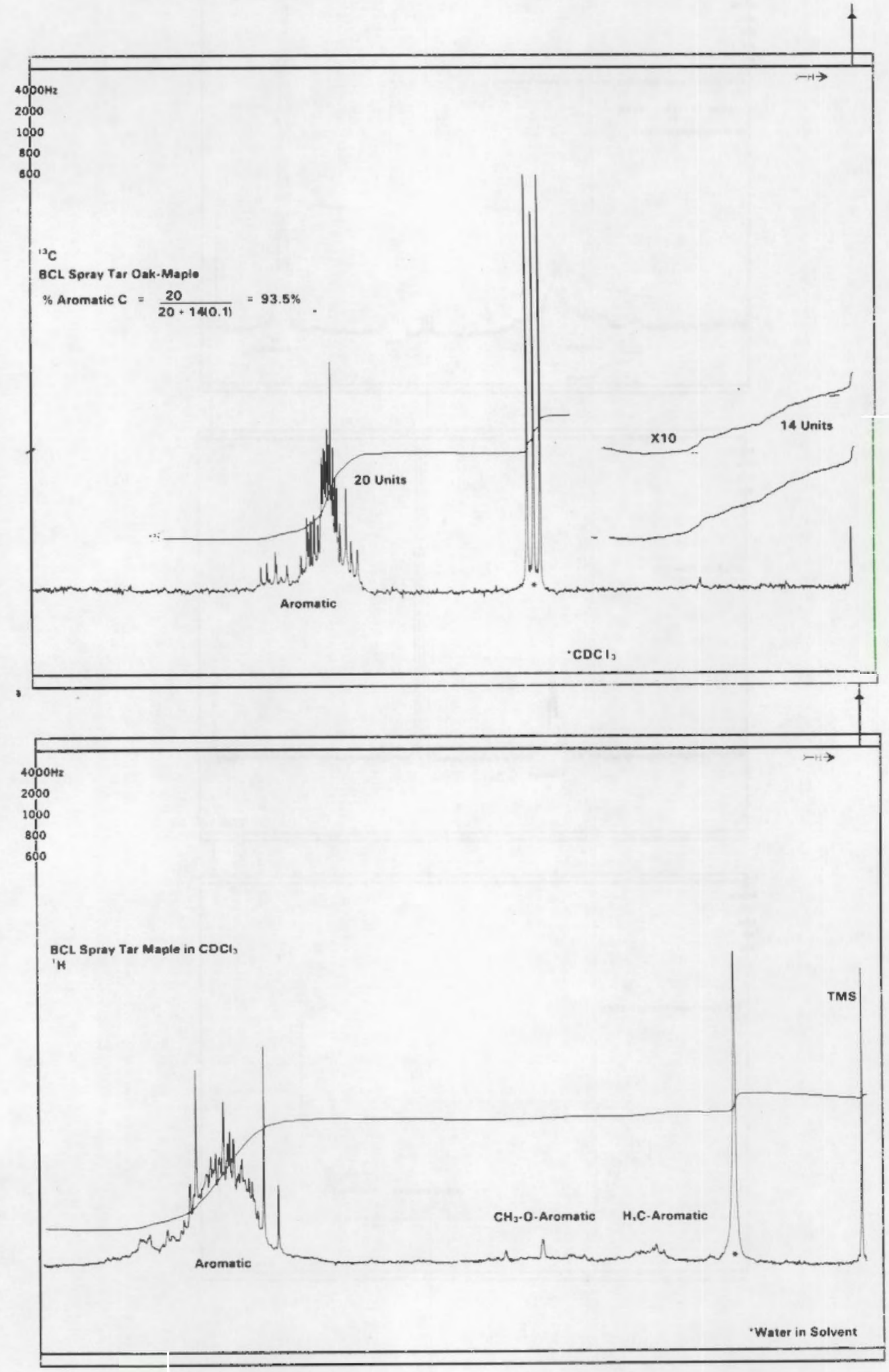

C. 4 
APPENDIX D

CHEMICAL COMPONENTS IDENTIFIED BY GAS CHROMATOGRAPHY / MASS SPECTROMETRY AND QUANTIFIED BY GAS CHROMATOGRAPHY (FID) IN BIOMASS PYROLYSIS/GASIFICATION CONDENSATES 
Table D-1. Chemical Components in Oxygenated Tars, by GC/MS.

\begin{tabular}{|c|c|c|c|c|}
\hline & $\begin{array}{l}\text { Georgia } \\
\text { Tech }\end{array}$ & $\begin{array}{l}\text { SERI } \\
\text { entrained }\end{array}$ & $\begin{array}{l}\text { Rome } \\
\text { Georgia }\end{array}$ & $\begin{array}{l}\text { Rocky } \\
\text { Creek }\end{array}$ \\
\hline 2-methyl-2-butenal & 0.44 & 0.25 & -- & $\overline{0}$ \\
\hline 3-methy $1-2-c y c l o p e n t e n-1-o n e$ & -- & -- & -- & 0.19 \\
\hline 2-hydroxy-3-methy 1-2-cyclopenten-1-one & 0.08 & -- & 0.25 & -- \\
\hline 2-furancarboxaldehyde & -- & -- & 0.10 & -- \\
\hline 2-furaninethanol & -- & -- & 0.89 & - \\
\hline phenol & 0.17 & 0.02 & 0.48 & 0.34 \\
\hline benzoic acid & -- & -- & -- & 0.08 \\
\hline 2-methylphenol & 0.13 & 0.02 & 0.23 & 0.12 \\
\hline 3-methyl and 4-methylphenol & 0.06 & 0.06 & 0.65 & 0.28 \\
\hline dimethylphenols & -- & -- & 0.48 & + \\
\hline methylbenzenediol & -- & -- & 0.47 & -- \\
\hline 2-methoxyphenol & 0.10 & 0.17 & 0.55 & 0.13 \\
\hline 4-methyl-2-methoxypheno? & 0.14 & 0.11 & 2.62 & 0.17 \\
\hline 4-ethy!-2-methoxyphenol & 0.01 & 0.04 & 0.62 & -- \\
\hline 4-propyl-2-me thoxyphenol & -- & -- & 0.22 & -- \\
\hline 4-propeny 1-2-methoxyphenol(3) & 0.07 & 0.21 & 1.78 & 0.09 \\
\hline 4-hydroxy-3-methoxybenzaldehyde & 0.25 & 0.32 & 0.33 & 0.22 \\
\hline 1-(4-hydroxy-3-me thoxypheny 1)-2-propanone & -- & -- & 0.35 & 0.07 \\
\hline 4-hydroxy-3-methoxybenzoic acid & -- & -- & 0.25 & -- \\
\hline 2,6-dimethoxyphenol & 0.24 & -- & 0.26 & 0.89 \\
\hline 4-methyl-2,6-dimethoxyphenol & 0.10 & -- & 0.22 & 0.96 \\
\hline 4-ethy $7-2,6$-dimethoxyphenol & 0.03 & -- & 0.18 & 0.55 \\
\hline 2,6-dinathoxy-4-propyiphenol & 0.04 & -- & -- & 0.15 \\
\hline 2,6-dimuthoxy-4-propenylphenols (3) & 0.08 & 0.09 & 0.18 & 1.19 \\
\hline 3,5-dimethoxy-4-hydroxybenzal dehyde & 0.21 & -- & -- & -- \\
\hline 4-acetyl-2,6-dime thoxyphenol & 0.11 & 0.06 & $-\infty$ & 0.27 \\
\hline $\begin{array}{l}\text { 1-(3,5-dimethoxy-4-hydroxypheny } 1) \text {, } \\
\text { 2-propanone }\end{array}$ & 0.04 & -+ & -- & 0.27 \\
\hline levoglucosan* & 0.58 & 0.68 & 0.20 & -- \\
\hline abietic acids & -- & -- & 0.51 & -- \\
\hline indene & -- & -- & -- & 0.03 \\
\hline naphthalene & 0.15 & 0.79 & 0.05 & -- \\
\hline 1-methylnaphtha?ene & - & -- & -- & 0.04 \\
\hline acenaphthylene & 0.10 & -- & 0.23 & 0.22 \\
\hline fluorene & -- & -- & -- & 0.09 \\
\hline phenanthrene & 0.03 & 0.27 & 0.10 & 0.30 \\
\hline anthracene & -- & -- & -- & 0.12 \\
\hline 1-phenylnaphthalene & - & -- & -- & 0.03 \\
\hline cyclopenta(d,e,f)phenanthrene & -- & -- & -- & 0.27 \\
\hline fluoran thene & 0.01 & -- & -- & 0.13 \\
\hline aceanthrylene & -- & -- & -- & 0.08 \\
\hline pyrene & -- & -- & -- & 0.08 \\
\hline acephenanthrylene & 0.01 & -- & -- & 0.18 \\
\hline benzo(a)pyrene & - & & -- 607 & $\frac{0.03}{7.659}$ \\
\hline TOTAL & $\frac{3}{1}: \frac{18 \%}{527}$ & $\frac{2.49 \%}{2.0 \%}$ & $\frac{11.60 \%}{0.00 \%}$ & $\frac{7.65 \%}{3}-\frac{35 \%}{50}$ \\
\hline Unidentified & & $2.0 \%$ & $8.00 \%$ & $3.35 \%$ \\
\hline
\end{tabular}

* the actual amount of levoglucosan is probably much higher as pure samples have given poor quantitative yields under these chromatography conditions. 
Table D-2. Chemical Components in Deoxygenated Tars, by GC/MS.

\begin{tabular}{|c|c|c|}
\hline & $\begin{array}{l}\mathrm{BCL}(\mathrm{a}) \\
\text { Hardwood }\end{array}$ & $\begin{array}{l}\text { SERI } \\
\text { Cracked } \\
\text { Crack }\end{array}$ \\
\hline phenol & -- & 0.50 \\
\hline dibenzofuran & 0.39 & -- \\
\hline naphthylcyanide & 0.02 & -- \\
\hline indene & 0.15 & 7.68 \\
\hline naphthalene & 1.76 & 14.12 \\
\hline 2-methylnaphthalene & 0.31 & 1.82 \\
\hline l-methylnaphthalene & 0.24 & 6.39 \\
\hline biphenyl & 0.36 & $-\infty$ \\
\hline acenaphthylene & 2.98 & 10.83 \\
\hline acenaphthene & 0.10 & 6.72 \\
\hline fluorene & 1.94 & 1.40 \\
\hline phenanthrene & 4.49 & 4.08 \\
\hline anthracene & 7.16 & - \\
\hline 1-phenylnaphthalene & 0.14 & - \\
\hline cyclopenta(def)phenanthrene & 0.98 & -- \\
\hline 2-phenylnaphthalene & 0.59 & - \\
\hline fluoranthene & 1.99 & 1.10 \\
\hline aceanthrylene & 0.79 & $\rightarrow$ \\
\hline pyrene & 0.14 & -- \\
\hline acephenanthrylene & 2.30 & 1.00 \\
\hline benz (a) anthracene & 0.88 & -- \\
\hline chrysene & 0.39 & - \\
\hline benzo(a)pyrene & 0.38 & -- \\
\hline TOTAL & $22.48 \%$ & $\overline{55.64}$ \\
\hline Unidentified & $6.92 \%$ & - \\
\hline
\end{tabular}

(a) a sample of BCL pine tar was also analyzed and gave nearly identical results; however, it was not strictly quantified.

(b) relative amounts only are given, not quantified as to actual amount in tar. 
T_ble D 3. Relative Amounts of Chemical Components

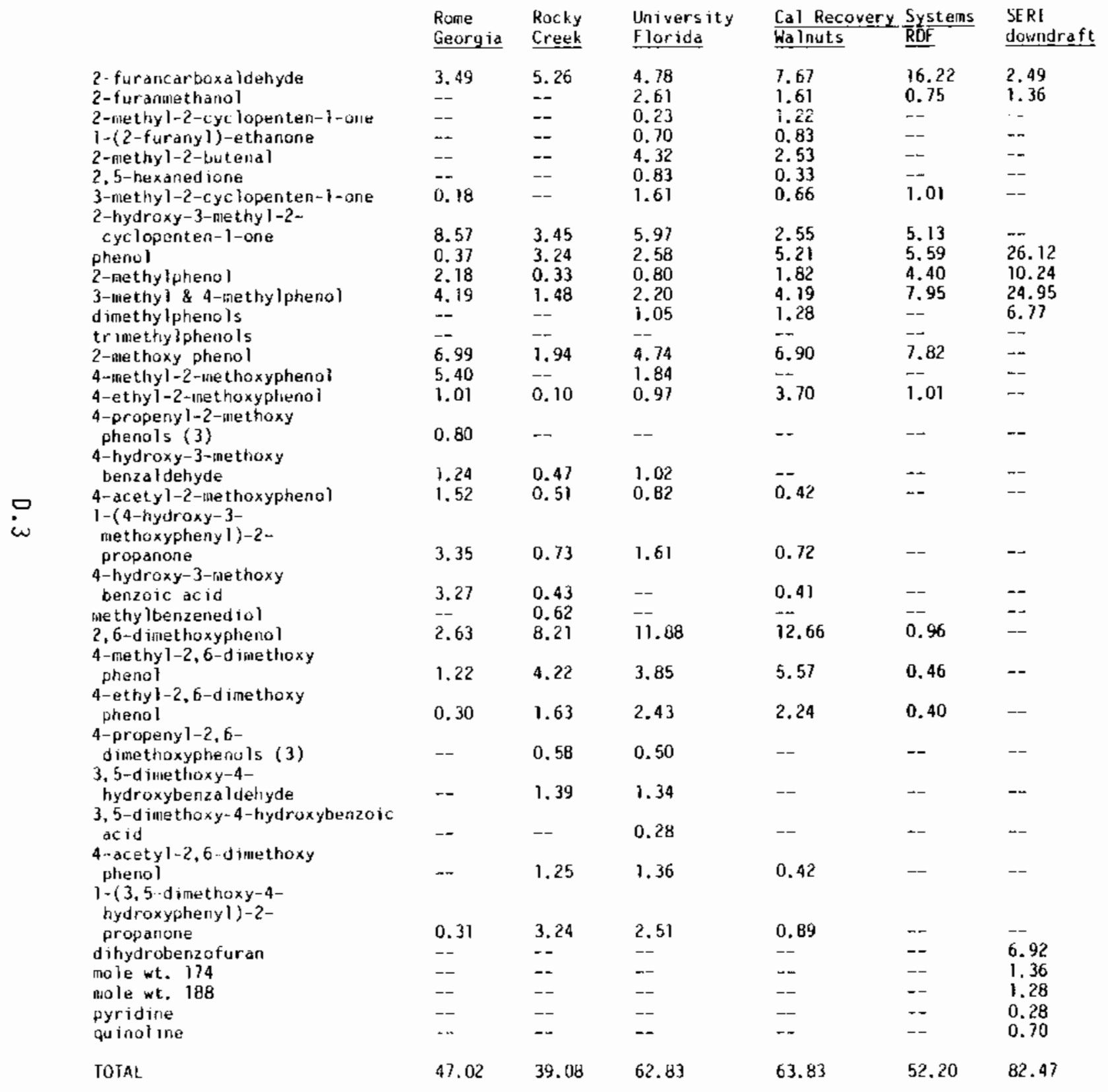


Table D-4. Relative Amounts of Chemical Comoonents in Fluidized-Bed Gasifier Aqueous Streams.

2-furancarboxaldehyde 2-furanmethanol

2-methy 1-2-cyclopenten-1-one

$T-(2-$ furany $T)$-ethanone

3-methy 1-2-cyc lopen ten-1 -one

2-nydroxy-3-methy i-2-

cycTopenten-T-one

cyclohexanone

phenol

2-methy 1 phenol

3-methyl \& 4-methylphenoi

dimethy phenois

trimethylphenols

benzaldehyde

benzenemethanol

2H-pyran-2-one

indanol

indanone

ace tophenone

dihydrobenzofuran

methy 1 dihydrobenzofuran

dimethyl-2H-oyran-2-one

benzopyran-?-one

biphenylol

methylbenzofuran

dibenzofuran

xanthene

dibenzodioxin

acetylnaphtha lenes (2)

mole t. 174

mole wt. 188

pyridine

Tethylpyridine( 3 )

benzonttrite

quinoline

indole

benzene

toluene

ethyibenzene

etheny lbenzene

indane

indene

naphthalene

me thy lnaph tha lenes (2)

biphenyl

acenaphthy lene

acenaph thene

fluorene

phenanthrene

anthracene

cyclopenta(def)phenanthrene

pheny l naph tha lenes ( 2 )

fluoranthene

acephenanthrylene

benzo (a) fluorene

benz (a)anthracene

chrysene

benzo(a)pyrene

Total

\begin{tabular}{|c|c|c|c|}
\hline $\begin{array}{l}\text { University } \\
\text { Missouri }\end{array}$ & PPAL & $\underline{\text { IGT }}$ & $\begin{array}{l}\mathrm{BCL} \\
\text { Pine }\end{array}$ \\
\hline$\rightarrow$ & 0.23 & -- & - \\
\hline-- & -- & -- & -- \\
\hline 0.57 & 0.15 & - & $=$ \\
\hline 0.25 & $\cdots$ & -- & -- \\
\hline T. 04 & -- & -- & $=$ \\
\hline- & -- & -- & -- \\
\hline 0.17 & -- & - & -- \\
\hline 25.38 & 12.02 & 12.69 & 0.20 \\
\hline 19.59 & 9.24 & trace & -- \\
\hline 24.04 & 27.30 & 0.42 & -- \\
\hline 9.48 & 1.17 & -- & -- \\
\hline 0.50 & -- & -- & $\rightarrow$ \\
\hline 0.09 & 3.28 & -- & - \\
\hline 0.50 & -- & -- & -- \\
\hline 0.15 & - & $=$ & -- \\
\hline 0.29 & 0.29 & -- & -- \\
\hline 0.53 & 2.29 & -- & -- \\
\hline 0.14 & -- & - & - \\
\hline 5.89 & 2.14 & - & -- \\
\hline- & 0.38 & $-i$ & -- \\
\hline 0.10 & -- & -- & -- \\
\hline- & 0.28 & - & -- \\
\hline$\ldots$ & 8.19 & -- & -- \\
\hline 1.21 & 2.57 & - & -- \\
\hline$\cdots$ & -- & 0.63 & 0.50 \\
\hline- & 0.47 & - & $=$ \\
\hline- & 1.27 & -- & - \\
\hline - & 0.40 & - & $=$ \\
\hline 0.17 & - & -- & -- \\
\hline 0.52 & -- & -- & -- \\
\hline 0.67 & 0.38 & 5.71 & -- \\
\hline 0.07 & 0.27 & 0.35 & -- \\
\hline 0.08 & 0.41 & 0.14 & -- \\
\hline- & 1.57 & 0.63 & - \\
\hline-- & 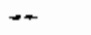 & 0.59 & -- \\
\hline- & -- & 15.63 & -- \\
\hline- & -- & 2.50 & $=-$ \\
\hline- & - & 0.11 & -- \\
\hline- & 0.17 & 0.39 & - \\
\hline- & -- & 0.25 & $\rightarrow$ \\
\hline -- & $\cdots$ & 2.57 & 5.99 \\
\hline- & 10.73 & 19.01 & 56.67 \\
\hline- & 0.17 & 1.20 & 0.20 \\
\hline- & - & 1.12 & 0.35 \\
\hline- & 1.22 & 3.38 & 10.14 \\
\hline$\rightarrow$ & -- & 2.71 & -- \\
\hline-- & -- & 3.16 & 1.17 \\
\hline-- & -- & 6.04 & 3.93 \\
\hline -- & -- & 1.28 & -- \\
\hline-- & $-m$ & 0.68 & -- \\
\hline- & -- & 0.26 & 0.20 \\
\hline$\rightarrow$ & -- & 3.34 & 1.50 \\
\hline-- & - & 2.95 & 1.61 \\
\hline$\rightarrow$ & - & 0.18 & - \\
\hline- & - & 0.47 & - \\
\hline+ & -- & 0.79 & -- \\
\hline$=$ & 二 & 0.49 & 0.11 \\
\hline 4.45 & 84.53 & 90.38 & 82.56 \\
\hline
\end{tabular}


APPENDIX E

NUMERICAL RESULTS OF AMES ASSAYS 
1A98 wis $\left(2 \mathrm{O}_{\mathrm{H}} \mathrm{i}\right)$

\begin{tabular}{|c|c|c|c|c|c|c|c|c|}
\hline$\mu g / p l a t e$ & $\begin{array}{l}\text { GA Tech } \\
\text { Tar }\end{array}$ & $\begin{array}{l}\text { SERI } \\
\text { Primary }\end{array}$ & $\begin{array}{l}\text { Rocky Creek } \\
\text { Tar }\end{array}$ & $\begin{array}{l}\text { Cal Recovery } \\
\text { Walnuts }\end{array}$ & $\begin{array}{l}\text { U MO } \\
\text { Solution }\end{array}$ & $\begin{array}{l}\text { PNL } \\
\text { Condensate }\end{array}$ & $\begin{array}{l}\text { IGT } \\
\text { Condensate }\end{array}$ & $\begin{array}{l}\mathrm{BCL} \\
\text { Maple/0ak }\end{array}$ \\
\hline $\begin{array}{r}2 \\
4 \\
8 \\
10 \\
20 \\
50\end{array}$ & $\begin{array}{l}56+3 \\
73 \pm 15 \\
45 \pm 8 \\
43+2 \\
39 \pm 8 \\
66 \pm 7\end{array}$ & $\begin{array}{l}64 \pm 9 \\
59+4 \\
50 \pm 11 \\
50 \pm 11 \\
58 \pm 4 \\
50 \pm 7\end{array}$ & $\begin{array}{l}58 \pm 2 \\
60 \pm 7 \\
57 \pm 3 \\
54 \pm 7 \\
55 \pm 9 \\
56 \pm 2\end{array}$ & $\begin{array}{l}67+6 \\
50+8 \\
50 \pm 1 \\
50+6 \\
56 \pm 2 \\
72 \pm 1\end{array}$ & $\begin{array}{l}69 \pm 8 \\
67 \pm 12 \\
52 \pm 1 \\
48 \pm 2 \\
62 \pm 0 \\
64 \pm 15\end{array}$ & $\begin{array}{l}68 \pm 0 \\
67 \pm 8 \\
66 \pm 0 \\
61 \pm 7 \\
59 \pm 3 \\
67 \pm 12\end{array}$ & $\begin{array}{l}58 \pm 7 \\
58 \pm 2 \\
55 \pm 4 \\
52 \pm 1 \\
60 \pm 6 \\
76 \pm 1\end{array}$ & $\begin{array}{l}79 \pm 8 \\
76 \pm 9 \\
68 \pm 2 \\
10 \overline{1} \pm 11 \\
126 \pm 24 \\
171 \pm 21\end{array}$ \\
\hline $\begin{array}{r}20 \\
40 \\
80 \\
100 \\
200 \\
500\end{array}$ & $\begin{array}{l}68+2 \\
55 \pm 9 \\
67 \pm 3 \\
57 \pm 1 \\
59 \pm 3 \\
58 \pm 8\end{array}$ & $\begin{array}{l}64 \pm 6 \\
58+4 \\
61 \pm 3 \\
64 \pm 1 \\
58 \pm 1 \\
56 \pm 5\end{array}$ & $\begin{array}{l}65+2 \\
54 \pm 2 \\
58 \pm 7 \\
70 \pm 4 \\
56 \pm 3 \\
62 \pm 3\end{array}$ & $\begin{array}{l}46 \pm 1 \\
52 \pm 1 \\
53 \pm 1 \\
57 \pm 3 \\
59 \pm 15 \\
61 \pm 1\end{array}$ & $\begin{array}{l}54+1 \\
51 \pm 3 \\
66 \pm 5 \\
65 \pm 4 \\
68+4 \\
59 \pm 5\end{array}$ & $\begin{array}{l}60 \pm 7 \\
54 \pm 5 \\
61 \pm 3 \\
75 \pm 7 \\
63 \pm 3 \\
70 \pm 5\end{array}$ & $\begin{array}{l}68 \pm 1 \\
73 \pm 2 \\
80 \pm 10 \\
76 \pm 1 \\
79 \pm 24 \\
107 \pm 4\end{array}$ & $\begin{array}{l}346 \pm 28 \\
140 \pm 75 \\
206 \pm 5 \\
203 \pm 2 \\
251 \pm 1 \\
251 \pm 10\end{array}$ \\
\hline $\begin{array}{l}\text { Correlation } \\
\text { Coefficient }\end{array}$ & $.03 / .01$ & $.18 / .10$ & $.03 / .03$ & $.40 / .57$ & $.03 / .08$ & $.06 / .33$ & $.83 / .85$ & $.91 / .52$ \\
\hline STope & $.12 / 0$ & $-.14 /-.01$ & $-.02 / .01$ & $.33 / .02$ & $.09 / .01$ & $.07 / .03$ & $.42 / .08$ & $2.21 / .29$ \\
\hline Y Intercept & $52.06 / 60.24$ & $56.81 / 60.4$ & $56.57 / 59.09$ & $52.61 / 51.66$ & $58.28 / 58.10$ & $62.14 / 59.00$ & $53.38 / 65.31$ & $66.78 / 139$ \\
\hline
\end{tabular}

[Data $A / B$ ( $A=$ value for lower concentration series, $B=$ value for higher concentration series)]

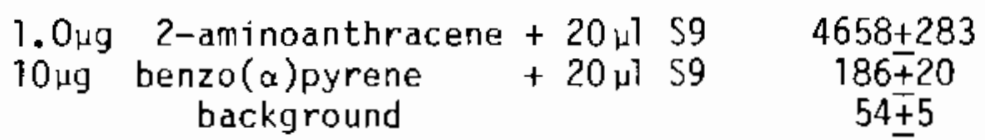


TA100w/S9 $(20 \mu 1)$

\begin{tabular}{|c|c|c|c|c|c|c|c|c|}
\hline$\mu g / p l a t e$ & $\begin{array}{l}\text { GA Tech } \\
\text { Tar }\end{array}$ & $\begin{array}{l}\text { SERI } \\
\text { Primary }\end{array}$ & $\begin{array}{l}\text { Rocky Creek } \\
\text { Tar }\end{array}$ & $\begin{array}{l}\text { Cal Recovery } \\
\text { Walnuts }\end{array}$ & $\begin{array}{l}\text { U MO } \\
\text { Solution }\end{array}$ & $\begin{array}{l}\text { PNL } \\
\text { Condensate }\end{array}$ & $\begin{array}{l}\text { IGT } \\
\text { Condensate }\end{array}$ & $\begin{array}{l}\text { BCL } \\
\text { Maple/0ak }\end{array}$ \\
\hline $\begin{array}{r}2 \\
4 \\
8 \\
10 \\
20 \\
50\end{array}$ & $\begin{array}{l}225+6 \\
212 \pm 9 \\
183 \pm 6 \\
209 \pm 2 \\
206 \pm 10 \\
221+20\end{array}$ & $\begin{array}{l}250+4 \\
234 \pm 6 \\
219+0 \\
208+5 \\
232 \pm 1 \\
244+16\end{array}$ & $\begin{array}{l}211 \pm 4 \\
226 \pm 17 \\
177 \pm 3 \\
210 \pm 10 \\
221 \pm 9 \\
280 \pm 6\end{array}$ & $\begin{array}{l}185 \pm 0 \\
220+0 \\
153 \pm 2 \\
182 \pm 11 \\
227 \pm 5 \\
245 \pm 13\end{array}$ & $\begin{array}{l}276 \pm 16 \\
242 \pm 2 \\
194 \pm 4 \\
178 \pm 4 \\
227 \pm 17 \\
236 \pm 2\end{array}$ & $\begin{array}{l}246+14 \\
232+1 \\
200+27 \\
218+1 \\
223+11 \\
230+11\end{array}$ & $\begin{array}{l}228+12 \\
240+2 \\
201 \pm 9 \\
272 \pm 6 \\
267 \pm 2 \\
321 \pm 18\end{array}$ & $\begin{array}{l}302+12 \\
316 \pm 25 \\
268+3 \\
327 \pm 25 \\
474 \pm 36 \\
561 \pm 3\end{array}$ \\
\hline $\begin{array}{r}20 \\
40 \\
80 \\
100 \\
200 \\
500\end{array}$ & $\begin{array}{l}219+2 \\
207+21 \\
258 \pm 6 \\
255 \pm 28 \\
287 \pm 8 \\
277 \pm 9\end{array}$ & $\begin{array}{l}240+23 \\
201+15 \\
246 \pm 14 \\
221 \pm 28 \\
294 \pm 7 \\
275+41\end{array}$ & $\begin{array}{l}244+9 \\
206 \pm 30 \\
249 \pm 9 \\
231 \pm 38 \\
279+21 \\
274+6\end{array}$ & $\begin{array}{l}251+12 \\
193+34 \\
215 \pm 5 \\
198+45 \\
242+2 \\
200+23\end{array}$ & $\begin{array}{l}250+2 \\
176+30 \\
236+12 \\
208+29 \\
256+9 \\
257+8\end{array}$ & $\begin{array}{l}236+3 \\
203+28 \\
224+5 \\
207+8 \\
222 \pm 2 \\
239+5\end{array}$ & $\begin{array}{l}300+27 \\
314+1 \\
346+43 \\
344+11 \\
388+20 \\
357+2\end{array}$ & $\begin{array}{l}442+42 \\
377 \pm 120 \\
384 \pm 13 \\
345 \pm 55 \\
420 \pm 67 \\
284 \pm 15\end{array}$ \\
\hline
\end{tabular}

Correlation

$\begin{array}{lllllllll}\text { Coefficient } .03 / .52 & .13 / .46 & .64 / .52 & .33 / .05 & 0.0 / .028 & .01 / .29 & .76 / .28 & .85 / .04\end{array}$

Slope $\quad .14 / .13 \quad .32 / .13 \quad 1.41 / .11 \quad 1.05 /-.03 \quad .07 / .09 \quad .10 / .04 \quad 6.44 /-.09$

Y Intercept 208.4/227.98 224.7/224.5 201.2/227.4 189.9/220.3 223.2/216.1 223.0/215.4 222.0/300.3 265.6/364.6

[Data $A / B$ ( $A=$ value for lover concentration series, $B=$ value for higher concentration series)]

\begin{tabular}{|c|c|c|c|}
\hline و و & $\begin{array}{l}2 \text {-aminoanthracene } \\
\text { benzo }(\alpha) \text { pyrene } \\
\text { background }\end{array}$ & $\begin{array}{l}+20 \leftarrow 759 \\
+20 \mu 159\end{array}$ & $\begin{array}{l}4755 \pm 183 \\
480 \pm 10 \\
216 \pm 7\end{array}$ \\
\hline
\end{tabular}


i

\begin{tabular}{|c|c|c|c|c|c|c|c|c|}
\hline$\mu g / p l a t e$ & $\begin{array}{l}\text { GA Tech } \\
\text { Tar }\end{array}$ & $\begin{array}{l}\text { SERI } \\
\text { Primary }\end{array}$ & $\begin{array}{l}\text { Rocky Creek } \\
\text { Tar }\end{array}$ & $\begin{array}{l}\text { Cal Recovery } \\
\text { Walnuts }\end{array}$ & $\begin{array}{l}\text { U MO } \\
\text { Solution }\end{array}$ & $\begin{array}{l}\text { PNL } \\
\text { Condensate }\end{array}$ & $\begin{array}{l}\text { IGT } \\
\text { Condensate }\end{array}$ & $\begin{array}{l}\mathrm{BCL} \\
\text { Maple/0ak }\end{array}$ \\
\hline $\begin{array}{r}20 \\
40 \\
80 \\
100 \\
200 \\
500\end{array}$ & $\begin{array}{l}32 \pm 3 \\
30 \pm 2 \\
21 \pm 2 \\
19 \pm 2 \\
31 \pm 3 \\
31 \pm 3\end{array}$ & $\begin{array}{l}18+1 \\
21 \pm 0 \\
28 \pm 5 \\
23 \pm 1 \\
22+1 \\
29+2\end{array}$ & $\begin{array}{l}29 \pm 4 \\
17 \pm 0 \\
28 \pm 6 \\
28 \pm 8 \\
28 \pm 5 \\
31 \pm 5\end{array}$ & $\begin{array}{l}27 \pm 4 \\
21 \pm 1 \\
25+3 \\
23+2 \\
25 \pm 4 \\
26 \pm 0\end{array}$ & $\begin{array}{l}25 \pm 0 \\
27 \pm 3 \\
22 \pm 3 \\
29 \pm 0 \\
29 \pm 2 \\
26 \pm 2\end{array}$ & $\begin{array}{l}28+5 \\
25 \pm 3 \\
29 \pm 2 \\
28 \pm 1 \\
25 \pm 6 \\
31 \pm 2\end{array}$ & $\begin{array}{l}34 \pm 3 \\
30 \pm 1 \\
33 \pm 2 \\
35 \pm 2 \\
33 \pm 2 \\
38 \pm 3\end{array}$ & $\begin{array}{l}62 \pm 17 \\
54 \pm 16 \\
61 \pm 2 \\
111 \pm 12 \\
78 \pm 10 \\
62 \pm 17\end{array}$ \\
\hline
\end{tabular}

\section{Correlation}

Coefficient .08

.28

.23

.04

.02

31

$62 \pm 17$

Slope $\quad .01$

.01

.01

0.0

0.0

01

.52

.03

$Y$ Intercept 25.96

22.22

25.03

24.38

26.04

26.4

.02

.03

Background $\quad 26 \pm 2$

TA $100 \mathrm{w} / 0 \mathrm{~S} 9$

\begin{tabular}{|c|c|c|c|c|c|c|c|c|}
\hline $\begin{array}{r}20 \\
40 \\
80 \\
100 \\
200 \\
500\end{array}$ & $\begin{array}{l}182 \pm 22 \\
204 \pm 15 \\
163 \pm 15 \\
181 \pm 8 \\
208 \pm 10 \\
256 \pm 2\end{array}$ & $\begin{array}{l}215 \pm 5 \\
233 \pm 16 \\
249 \pm 10 \\
239 \pm 7 \\
272 \pm 28 \\
373 \pm 5\end{array}$ & $\begin{array}{l}209+14 \\
170 \pm 15 \\
206 \pm 2 \\
218+3 \\
240+5 \\
230 \pm 17\end{array}$ & $\begin{array}{l}240+6 \\
237 \pm 29 \\
215 \pm 2 \\
199 \pm 11 \\
203 \pm 7 \\
235 \pm 20\end{array}$ & $\begin{array}{l}224 \pm 18 \\
195 \pm 36 \\
243 \pm 12 \\
225 \pm 3 \\
217 \pm 3 \\
223 \pm 9\end{array}$ & $\begin{array}{l}251+1 \\
224+28 \\
221 \pm 5 \\
219 \pm 16 \\
240+22 \\
239 \pm 3\end{array}$ & $\begin{array}{l}239 \pm 28 \\
266 \pm 20 \\
231 \pm 8 \\
261 \pm 2 \\
220 \pm 21 \\
252 \pm 14\end{array}$ & $\begin{array}{l}252 \pm 46 \\
261 \pm 3 \\
198 \pm 7 \\
214 \pm 4 \\
231 \pm 22 \\
232 \pm 14\end{array}$ \\
\hline $\begin{array}{l}\text { Correlation } \\
\text { Coefficient }\end{array}$ & .50 & .99 & .25 & .01 & .01 & .11 & .03 & 0.0 \\
\hline Slope & .12 & .31 & .06 & .01 & .01 & .02 & .02 & -.01 \\
\hline Y Intercept & 185.3 & 215.6 & 204.6 & 220.2 & 220.0 & 227.4 & 238.9 & 230.5 \\
\hline
\end{tabular}

Background $\quad 220 \pm 17$ 


\begin{tabular}{|c|c|c|c|c|c|}
\hline$\mu g / p l a t e$ & $\begin{array}{l}\text { Rome GA } \\
\text { Tar }\end{array}$ & $\begin{array}{l}\text { U FL } \\
\text { Condensate }\end{array}$ & $\begin{array}{l}\text { SERI } \\
\text { Condensate }\end{array}$ & $\begin{array}{l}\mathrm{BCL} \\
\text { Pine }\end{array}$ & \\
\hline $\begin{array}{r}2 \\
4 \\
8 \\
10 \\
20 \\
50\end{array}$ & $\begin{array}{l}56+3 \\
40 \pm 4 \\
33 \pm 3 \\
42+2 \\
40+6 \\
39+4\end{array}$ & $\begin{array}{l}47 \pm 4 \\
67 \pm 10 \\
46 \pm 9 \\
46 \pm 5 \\
57 \pm 0 \\
53 \pm 2\end{array}$ & $\begin{array}{l}41+4 \\
47 \pm 18 \\
46 \pm 2 \\
55 \pm 3 \\
48 \pm 9 \\
45 \pm 10\end{array}$ & $\begin{array}{l}94 \pm 5 \\
70 \pm 14 \\
115 \pm 38 \\
149 \pm 16 \\
185 \pm 3 \\
242 \pm 31\end{array}$ & \\
\hline $\begin{array}{r}20 \\
40 \\
80 \\
100 \\
200 \\
500\end{array}$ & $\begin{array}{l}36 \pm 6 \\
38 \pm 11 \\
47 \pm 4 \\
40 \pm 6 \\
49 \pm 3 \\
46 \pm 4\end{array}$ & $\begin{array}{l}59 \pm 5 \\
49 \pm 1 \\
68 \pm 20 \\
51 \pm 3 \\
47 \pm 4 \\
47 \pm 5\end{array}$ & $\begin{array}{l}57 \pm 13 \\
58 \pm 4 \\
46 \pm 2 \\
41 \pm 9 \\
57 \pm 7 \\
62 \pm 1\end{array}$ & $\begin{array}{l}254 \pm 11 \\
309 \pm 19 \\
210 \pm 26 \\
329 \pm 5 \\
374 \pm 30 \\
393 \pm 29\end{array}$ & $\begin{array}{l}82+9 \\
100 \pm 19 \\
144 \pm 22 \\
113 \pm 3 \\
162 \pm 21 \\
226 \pm 24\end{array}$ \\
\hline $\begin{array}{l}\text { Correlation } \\
\text { Coefficient }\end{array}$ & $0.0 / .35$ & $.09 / 0.0$ & $.08 / .28$ & $.81 / .41$ & .87 \\
\hline Slope & $0 / .03$ & $.27 / 0.0$ & $.14 / .04$ & $3.76 / .46$ & .30 \\
\hline Y Intercept & $39.4 / 36.7$ & $46.0 / 49.6$ & $42.7 / 44.4$ & $75.4 / 208.3$ & 85.4 \\
\hline Background & $26 \pm 5$ & & & & $(56 \pm 5)$ \\
\hline $\begin{array}{l}.02 \\
.04 \\
.08 \\
.10 \\
.20 \\
.50\end{array}$ & $\begin{array}{l}57 \pm 7 \\
69 \pm 0 \\
62 \pm 5 \\
70 \pm 11 \\
66 \pm 4 \\
73 \pm 0\end{array}$ & $\begin{array}{l}85 \pm 21 \\
74 \pm 2 \\
49 \pm 1 \\
51 \pm 0 \\
68+10 \\
78 \pm 6\end{array}$ & $\begin{array}{l}68 \pm 2 \\
69 \pm 4 \\
47 \pm 1 \\
55 \pm 3 \\
64 \pm 2 \\
70 \pm 3\end{array}$ & $\begin{array}{l}52+2 \\
70 \pm 4 \\
47 \pm 4 \\
55 \pm 6 \\
76 \pm 3 \\
64 \pm 2\end{array}$ & \\
\hline $\begin{array}{l}.20 \\
.40 \\
.80 \\
1.0 \\
2.0 \\
5.0\end{array}$ & $\begin{array}{l}75 \pm 2 \\
65 \pm 0 \\
61 \pm 0 \\
63 \pm 15 \\
68 \pm 1 \\
41 \pm 2\end{array}$ & $\begin{array}{l}67 \pm 3 \\
45 \pm 10 \\
71 \pm 12 \\
62 \pm 10 \\
73 \pm 5 \\
79 \pm 9\end{array}$ & $\begin{array}{l}70 \pm 6 \\
48 \pm 14 \\
68 \pm 7 \\
52 \pm 16 \\
62 \pm 15 \\
67 \pm 8\end{array}$ & $\begin{array}{l}74 \pm 1 \\
52 \pm 22 \\
71 \pm 2 \\
64 \pm 14 \\
71 \pm 3 \\
95 \pm 1\end{array}$ & \\
\hline $\begin{array}{l}\text { Correlation } \\
\text { Coefficient }\end{array}$ & $.09 / .80$ & $.01 / .22$ & $.01 / 0.0$ & $.01 / .52$ & \\
\hline Slope & $11.2 /-6.0$ & $9.27 / 3.08$ & $4.86 / 0.2$ & $6.67 / 5.38$ & \\
\hline Y Intercept & $66.1 / 72.2$ & $67.5 / 63.4$ & $63.5 / 63.0$ & $62.0 / 64.6$ & \\
\hline Background & $76+10$ & & & & \\
\hline
\end{tabular}




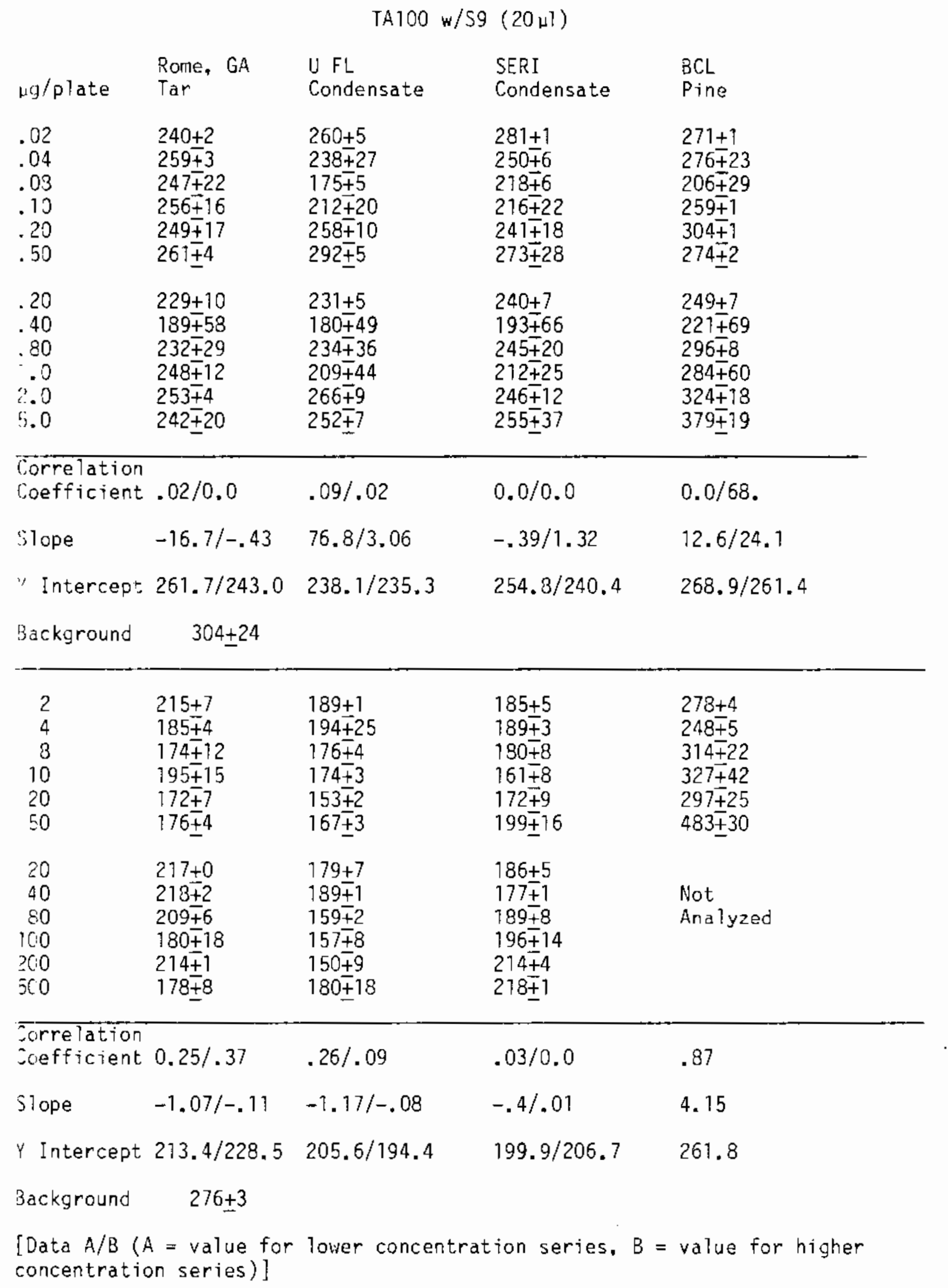


TA98 w/o S9

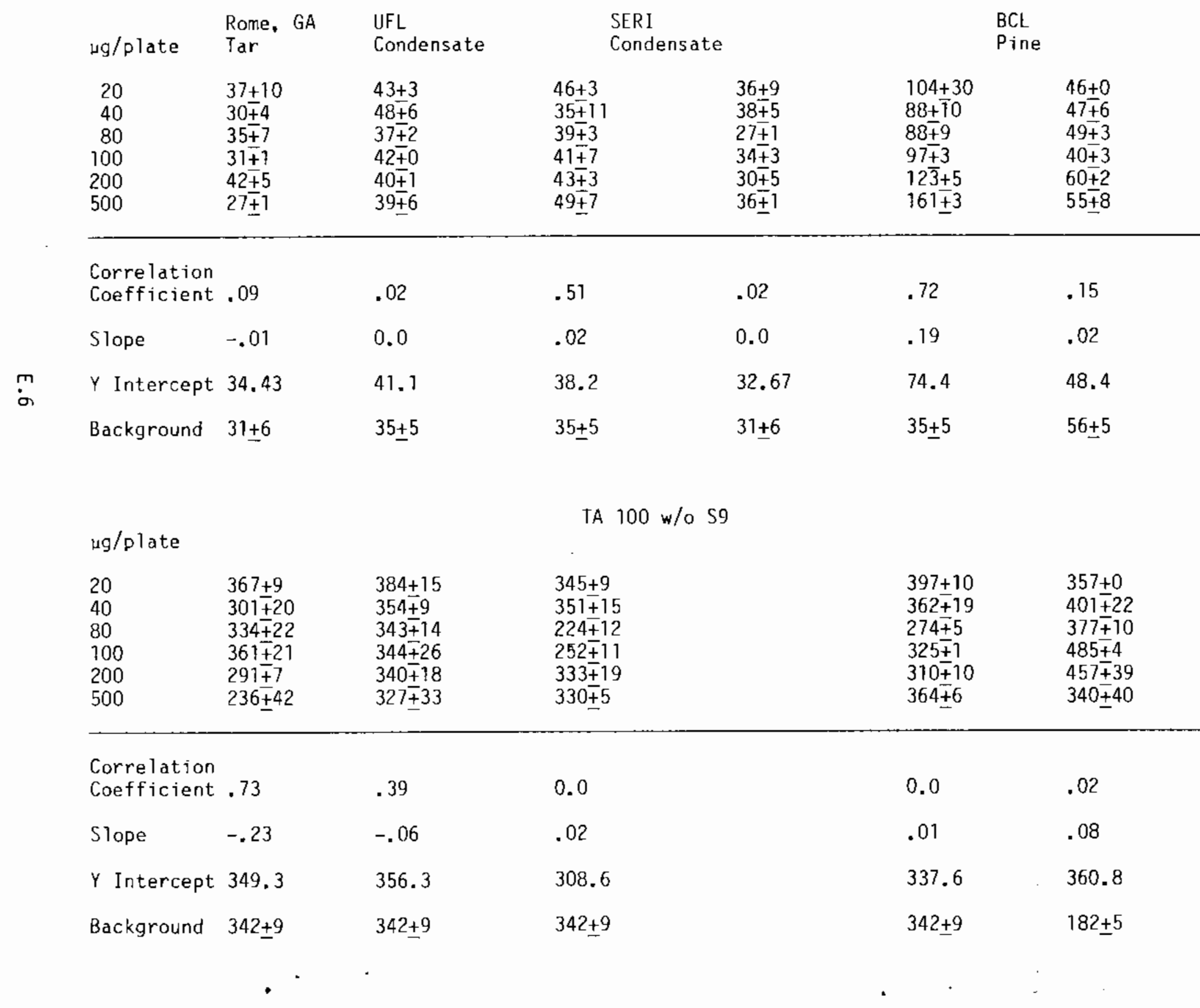


TAT00 w/S9 $(20 \mu 1)$

$\begin{array}{rlllll}\text { wg/plate } & \begin{array}{l}\text { Rome, GA } \\ \text { Aqueous }\end{array} & \begin{array}{l}\text { Rocky Creek } \\ \text { Aqueous }\end{array} & \begin{array}{l}\text { Cal Recovery } \\ \text { RDF }\end{array} & \begin{array}{l}\text { BCL Pine } \\ \text { Aqueous }\end{array} & \begin{array}{l}\text { SERI* } \\ \text { Cracked }\end{array} \\ 100 & 302 \pm 4 & 364 \pm 32 & 364 \pm 1 & 360 \pm 8 & 357 \pm 23 \\ 200 & 331 \pm 21 & 377 \pm 3 & 324 \pm 15 & 368 \pm 10 & 345 \pm 23 \\ 400 & 358 \pm 5 & 355 \pm 25 & 348 \pm 37 & 371 \pm 9 & 328 \pm 25 \\ 500 & 354 \pm 14 & 358 \pm 0 & 370 \pm 8 & 338 \pm 3 & 330 \pm 28 \\ 1000 & 322 \pm 28 & 387 \pm 5 & 367 \pm 11 & 339 \pm 28 & 115 \pm 8 \\ 2500 & 334 \pm 16 & 361 \pm 19 & 358 \pm 10 & 345 \pm 14 & \mathrm{~K}\end{array}$

Correlaticn

Slope $\quad-.01 \quad-.01 \quad$.

Y Intercept $349.2 \quad 375.8$

364.1

.30

.90

Background $402 \pm 40, K=$ culture killed

TA $w / 0$ S9

$\begin{array}{rlllll}100 & 332 \pm 12 & 327 \pm 36 & 351 \pm 12 & 309+27 & 325 \pm 7 \\ 200 & 330 \pm 47 & 324 \pm 34 & 337 \pm 12 & 336 \pm 6 & 375 \pm 18 \\ 400 & 354 \pm 15 & 356 \pm 12 & 317 \pm 7 & 305 \pm 26 & 394 \pm 25 \\ 500 & 341 \pm 14 & 357 \pm 18 & 336 \pm 16 & 317 \pm 16 & 326 \pm 20 \\ 1000 & 364 \pm 9 & 372 \pm 15 & 316 \pm 5 & 324 \pm 25 & 181 \pm 27 \\ 2500 & 366 \pm 1 & 366 \pm 22 & 321 \pm 19 & 330 \pm 21 & k\end{array}$

Correlation

Coefficient. 39

.30

.37

0.0

.63

Slope $\quad .01$

.01

$-.01$

0.0

$-.17$

Y Intercept 342.1

343.5

341.5

326.0

387.8

Background $358 \pm 24$

$k=$ Culture Killed

* Hand-Counted Results Only 


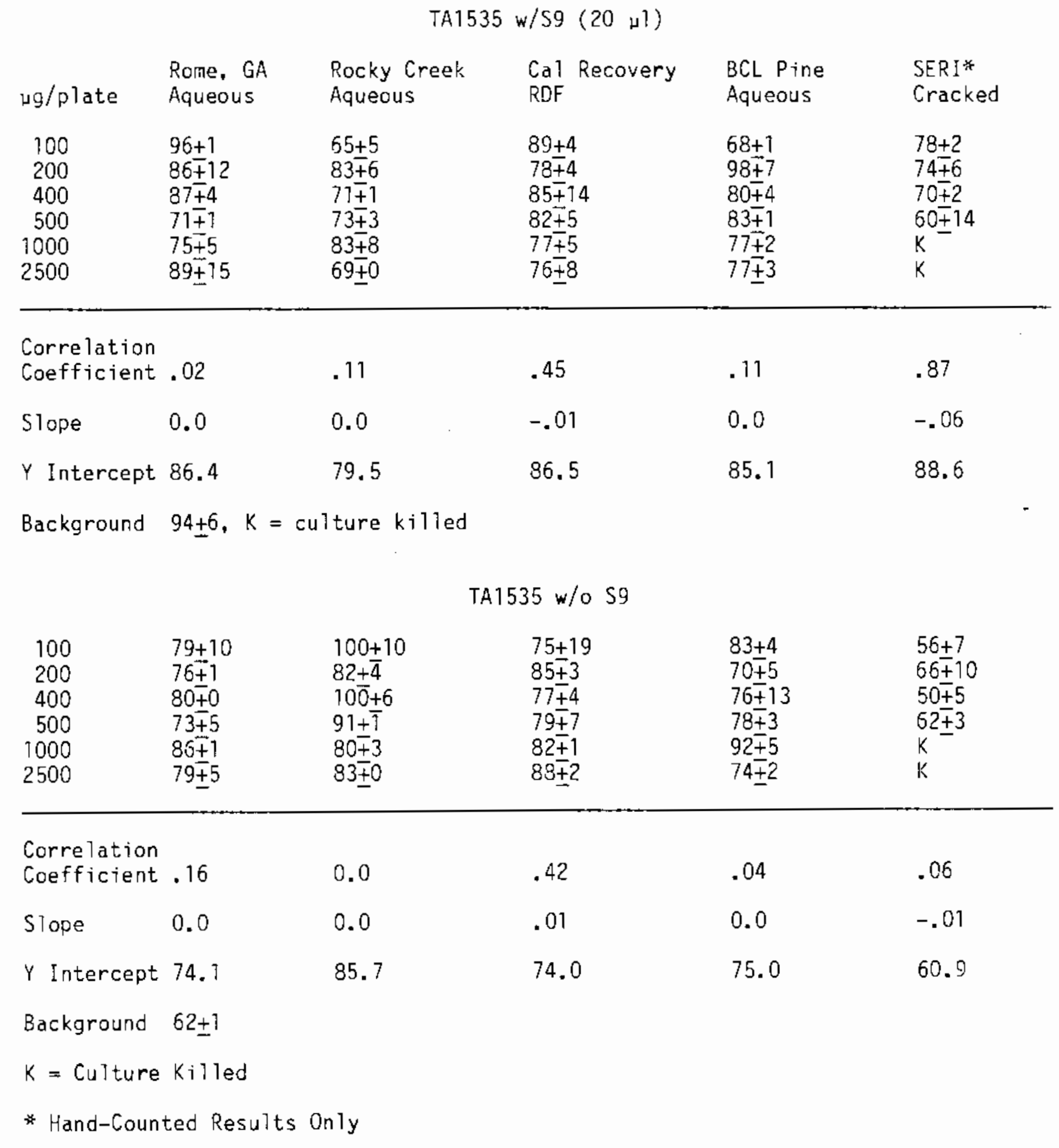




$$
\text { TA } 1537 \mathrm{w} / \mathrm{Sg}(20 \mu \mathrm{H})
$$

$\begin{array}{llllll}: 19 / \text { plate } & \begin{array}{l}\text { Rome, GA } \\ \text { Aqueous }\end{array} & \begin{array}{l}\text { Rocky Creek } \\ \text { Aqueous }\end{array} & \begin{array}{l}\text { Cal Recovery } \\ \text { RDF }\end{array} & \begin{array}{l}\text { BCL Pine } \\ \text { Aqueous }\end{array} & \begin{array}{l}\text { SERI* } \\ \text { Cracked }\end{array} \\ 100 & 29 \pm 3 & 116 \pm 1 & 103 \pm 9 & 122 \pm 2 & 20 \pm 4 \\ 200 & 18 \pm 1 & 126 \pm 5 & 132 \pm 10 & 118 \pm 18 & 21 \pm 6 \\ 400 & 23 \pm 4 & 124 \pm 12 & 135 \pm 3 & 130 \pm 1 & 21 \pm 2 \\ 500 & 20 \pm 2 & 133 \pm 1 & 116 \pm 1 & 129 \pm 5 & 22 \pm 3 \\ 1000 & 29 \pm 2 & 126 \pm 18 & 124 \pm 3 & 125 \pm 3 & \mathrm{~K} \\ 2500 & 27 \pm 7 & 115 \pm 3 & 123 \pm 1 & 117 \pm 6 & \mathrm{~K}\end{array}$

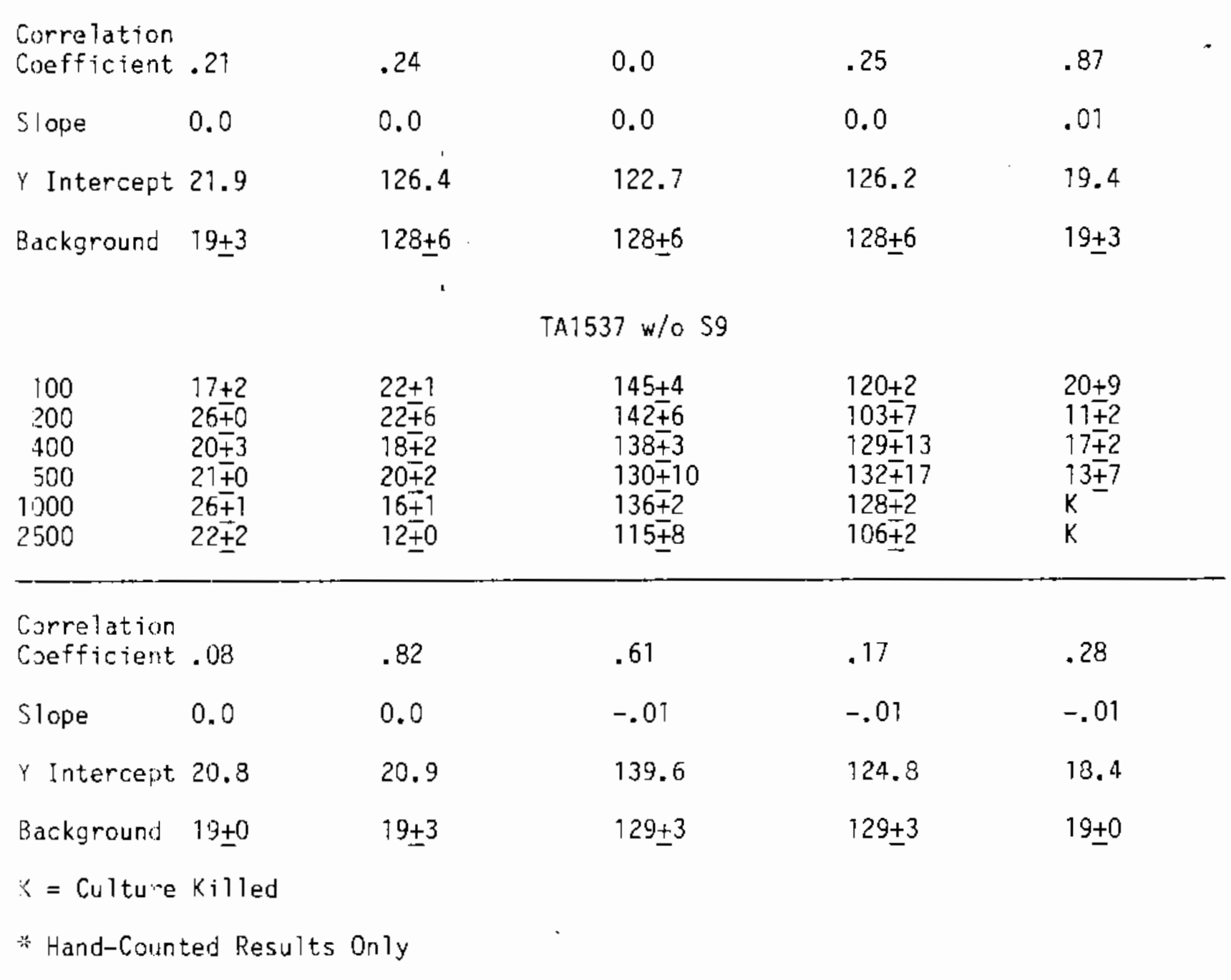


•

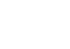


PNL-5555

UC-61a

\title{
DISTRIBUTION LIST
}

No. of

Copies

\section{OFFSITE}

$2 M r$. Simon Friedrich

Biomass Energy Technology Division

U.S. Department of Energy

Forrestal Building (CE-321)

1000 Independence Avenue

Washington, DC 20585

Dr. Beverly Berger, Director

Biomass Energy Technology Division

U.S. Department of Energy

Forrestal Building (CE-32T)

1000 Independence Avenue

Washington, DC 20585

30 DDE Technical Information Lenter

\author{
Dr. Suresh Babu \\ Institute of Gas Technology \\ IIT Center \\ 3124 South State Street \\ Chicago, IL 60616 \\ Dr. James P. Diebold \\ Solar Energy Research Institute \\ 1517 Cole Boulevard \\ Golden, CO 80401 \\ Mr. Herman F. Feldmann \\ Battelle - Columbus Laboratories \\ $505 \mathrm{King}$ Avenue \\ Columbus, $\mathrm{OH} 4320$ ? \\ Dr. Virgil J. Flanigan \\ Gasification Research On Wood \\ University of Missouri-Rolla \\ Rolla, MO 65401 \\ Mr. Robert H. Hargrave \\ Rocky Creek Farm Gasogens, Inc. \\ P.0. Box 326 \\ LaCrosse, FL 32658
}

Dr. James A. Knight

Energy and Materials Sciences Laboratory

Eng. Expt. Station, Area 2

Georgia Institute of Technology

Atlanta, GA 30332

Mr. Ben Levie

Solar Energy Research Institute 1677 Cole Boulevard

Golden, CO 80401

Mr. Thomas F. McGowan

Wood Energy Systems Branch

Eng. Experimenta1 Station

Georgia Institute of Technology

Atlanta, GA 30332

Dr. Thomas A. Milne

Solar Energy Research Institute 1617 Cole Boulevard

Golden, CO 80401

Mr. Billy J. Nicholson, Jr.

Northwest Georgia Regiona]

Hospital

1305 Redmond Rd.

Rome, GA 30161

Mr. Mark Paisley

Battelle, Columbus Laboratories 505 King Avenue

Columbus, $\mathrm{OH} \quad 43201$

Dr. Tom Reed

Solar Energy Research Institute

1617 Cole Boulevard

Golden, Co 80401 
No. of

Copies

Mr. George M. Savage

Vice President

Cal Recovery Systems, Inc.

160 Broadway. Suite 200

Richmond, CA 94804

Dr. Lawrence N. Shaw

Department of Agricultural Eng.

University of Florida

Frazier-Rogers Hall

Gainesvilie, FL 32671

Mr. James L. Walsh, Jr. Energy Systems Group

Eng. Experimental Station

Georgia Institute of Technology

Atlanta, GA 30332

\section{FOREIGN}

Mr. Jarmo Hallikas

Valtion Teknillinen Tutkimuskeskus

Suunnitelu-ja markkinointitoimisto

Vuorimiehentie 5, 02750 Espoo

FINLAND

Mr. Donald S. Scott

Department of Chemical Engineering University of Water loo

Waterloo, Ontario

CANADA N2L 3G1
No. of

Copies

ONSITE

DOE Richland Operations Office

D. K. Jones/D. R. Segna

46 Pacific Northwest Laboratory

E. G. Baker

M. D. Brown

T. D. Chikalla

D. C. Elijott (10)

J. A. Franz

M. A. Gerber (15)

K. M. McFadden

L. K. Mudge

T. R. Pah1

W. F. Riemath

R. W. Sanders

G. F. Schiefelbein

L. J. Sealock, Jr.

D. J. Stevens

D. L. Stewart

P. C. Walkup

Publishing Coordination (2)

Technica? Information (5) 